\title{
AVALIAÇÃO DO DESGASTE E RUGOSIDADE SUPERFICIAL DE MATERIAIS UTILIZADOS PARA SELANTE, SUBMETIDOS À ESCOVAÇÃO COM DOIS DIFERENTES DENTIFRÍCIOS
}

\author{
Daniela Rios
}

Dissertação apresentada à Faculdade de Odontologia de Bauru, da Universidade de São Paulo, como parte dos requisitos para obtenção do título de mestre em Odontologia, na área de Odontopediatria.

(Edição Revisada)

Bauru

2000 


\title{
AVALIAÇÃO DO DESGASTE E RUGOSIDADE SUPERFICIAL DE MATERIAIS UTILIZADOS PARA SELANTE, SUBMETIDOS À ESCOVAÇÃO COM DOIS DIFERENTES DENTIFRÍCIOS
}

\author{
Daniela Rios
}

Dissertação apresentada à Faculdade de Odontologia de Bauru, da Universidade de São Paulo, como parte dos requisitos para obtenção do título de mestre em Odontologia, na área de Odontopediatria.

(Edição Revisada)

Orientador: Prof ${ }^{\underline{a}} \operatorname{Dr}^{\underline{a}}$ Maria Aparecida de Andrade Moreira Machado

Bauru

2000 
Rios, Daniela

R479a Avaliação do desgaste e rugosidade superficial de materiais utilizados para selante, submetidos a teste de escovação com dois diferentes dentifrícios./ Daniela Rios - Bauru, 2000.

$149 p$; il. ; $30 \mathrm{~cm}$.

Tese, (Mestrado) - Faculdade de Odontologia de Bauru. USP.

Orientador: $\operatorname{Prof}^{\underline{a}} \mathrm{Dr}^{\underline{a}}$ Maria Aparecida de Andrade Moreira Machado

Autorizo, exclusivamente para fins acadêmicos e científicos, a reprodução total ou parcial desta dissertação/tese, por processos fotocopiadores e/ou meios eletrônicos.

Assinatura do autor:

Data:

1 


\section{Dados Curriculares}

\section{Daniela Rios}

12 de Janeiro de 1975

São Paulo - SP

1993-1996

$1998-2000$

Associações
Nascimento

Curso de Odontologia - Faculdade

de Odontologia de Bauru - USP.

Curso de Pós-Graduação em

Odontopediatria em nível de

Mestrado - Faculdade de

Odontologia de Bauru - USP.

APCD - Associação Paulista de

Cirurgiões Dentistas

SBPqO- Sociedade Brasileira de

Pesquisa Odontológica

IADR- International Association for

Dental Research 
"Nos momentos em que somos tomados pelo desafio de trilhar um caminho certo, porém, surpreendentemente árduo, fica difícil não nos desencorajarmos. No entanto, por meio da força de Deus, presente em cada um de nós, e através do amor, conseguimos superar todas as dificuldades." 


\section{DEDICATÓRIA}

\section{Aos meus pais, Atair e Marli,}

Vocês foram a lição mais forte de minha vida, me transmitindo o maior dos conhecimentos, o amor. Se estamos aptos para amar, não há porque questionarmos o sofrer, pois só há realmente a dor, quando não somos capazes ou auto-suficientes para entender o amor. No entanto, muitas vezes como ser humano limitado que sou, não priorizo este princípio, e nestes momentos o amor de vocês é tão grande que é capaz de amar por mim, amenizando meu sofrer. Dedico a vocês toda minha vida e todas minhas conquistas pois são advindas deste amor.

\section{Aos meus irmãos: Coralli, Wilson, Guilherme e Carol}

Que, cada um de sua forma, conquistou sua importância em minha vida, tornando-me uma pessoa mais completa e consequentemente mais feliz. Vocês representam a todo momento uma fonte de inspiração e força para continuar nesta longa caminhada.

\section{Ao Heitor}

Uma pessoa muito especial que vem se tornando cada vez mais importante em minha vida, que soube me compreender durante todo o período de confecção da Tese, amenizando minhas dificuldades, me ajudando e me mostrando sempre o lado positivo das situações.

A vocês, com infinito amor, dedico este trabalho. 


\section{AGRADECIMENTOS ESPECIAIS}

À minha orientadora, Prof.a. Dra. Maria Aparecida de Andrade Moreira Machado, por me carregar, enquanto me ensinava a andar, pelos caminhos da Odontopediatria, e posteriormente por me soltar, para que eu atingisse maturidade para caminhar com minhas próprias pernas. Meus sinceros agradecimentos pelo incentivo e confiança que sempre me dedicou.

Ao Prof. Dr. Paulo Amarante de Araújo pela ternura e paciência com que me transmitiu alguns, de seus vários conhecimentos, que foram de infinita importância para conclusão desta dissertação.

Ao Prof. Dr. Ricardo Marins de Carvalho por estar sempre presente, pronto para dividir sua singular experiência científica e seus vastos conhecimentos literários, sendo um dos responsável pelo enriquecimento do trabalho.

Às minhas grandes amigas: Linda, Lívia e Ana Luíza, por estarem ao meu lado em cada passo e em cada emoção sentida durante a elaboração deste trabalho; Claudia, Débora, Luciana e Paula, por , mesmo à distância, me ajudarem a superar as dificuldades. Muito obrigada, várias vezes uma boa palavra, um sorriso de incentivo ou um pensamento construtor, foram o ponto de partida para me lembrar que as dificuldades são passageiras, e que viver, em quaisquer circunstâncias, é muito prazeroso quando se tem amigas como vocês. 


\section{AGRADECIMENTOS}

À Faculdade de Odontologia de Bauru da Universidade de São Paulo, na pessoa de seu Diretor Prof. Dr. Aymar Pavarini e do Coordenador da Pós-Graduação Prof. Dr. Luiz Fernando Pegoraro.

Aos professores do Departamento de Odontopediatria da FOB-USP, Dr. Aymar Pavarini, Dr. Bernardo Gonzalez Vono, Dr ${ }^{\mathrm{a}}$. Maria $\mathrm{Dr}^{\mathrm{a}}$. Francisca Thereza Borro Bijella, Dr. Ruy César Camargo Abdo e $\mathrm{Dr}^{\mathrm{a}}$. Salete Moura Bonifácio da Silva, pelo empenho e satisfação ao transmitirem seus conhecimentos, sendo os responsáveis por despertar em mim, o amor pela especialidade.

Aos colegas de Pós-Graduação, Adriano, Ana Carla, Ana Luiza, Cleide, Fernanda, Lívia, Marina, Patrícia, Paloma, Maria Lígia e Fabiana pela amizade que me encorajou a continuar trilhando meu caminho mesmo nos momentos mais difíceis e por se fazerem presentes nas horas de alegria.

Aos funcionários do Departamento de Odontopediatria da FOB-USP, Fátima, Lia, Kelle, Lilian, Maria Estela, Paulo e Wilma pela atenção, solicitude e principalmente amizade com que sempre me trataram.

Ao professor Dr. José Roberto Pereira Lauris, do Departamento de Odontologia Social da FOB-USP, pelos esclarecimentos sobre a análise estatística. 
Aos professores do Departamento de Materiais Dentários da FOBUSP: Dr. César Antunes de Freitas e Dr. Paulo Afonso Silveira Franciscone pelo carinho com que me receberam no departamento.

Ao técnico de Laboratório do Departamento de Materiais Dentários da FOB-USP, Alcides Urias da Costa, pela confecção dos moldes para obtenção dos corpos de prova, e pela constante ajuda durante a fase laboratorial.

Aos funcionários da FOB-USP, Lourisvalda e Sandra (Materiais Dentários); Osni (Microbiologia), Telma e Ovídio (Bioquímica) e Nelson (Dentística) por serem muito solícitos, e mesmo sem terem a menor obrigação, estiveram sempre prontamente dispostos a me ajudar.

Ao Departamento de Dentística da FOB-USP, na pessoa do Prof. Dr. Rafael Lia Mondelli, pela prontidão de empréstimo dos equipamentos para a condução deste trabalho.

Ao professor Dr. José Mondelli do Departamento de Dentística da FOB-USP, pelo seu Dom de ensinar, sempre com amor dedicação e simplicidade, tornando-se minha referência de docência a ser seguida.

Aos amigos: Bia, Marcela, Cinthia, Ana Eliza, Sandra, Renata (Baiana), Wagner, Pedro, Celiane, Dani Cefaly, Fernanda, Rosa, Nicole, Carla, Flávia, Marcelo, Jefferson, Paulo e Alessandro por ajudarem a transformar minha existência em vivência, através de um sentimento grandioso: a amizade. 
À bibliotecária Valéria, pela revisão bibliográfica e aos demais funcionários da biblioteca pela orientação nos demais trabalhos científicos.

À instituição de fomento CAPES, pelo apoio financeiro.

A todos que, ao longo destes dois anos, fizeram parte do meu dia a dia, e com um sorriso ou um aceno de mão, tornaram este tempo inesquecível e me deram a certeza de que valeu a pena. 


\section{SUMÁRIO}

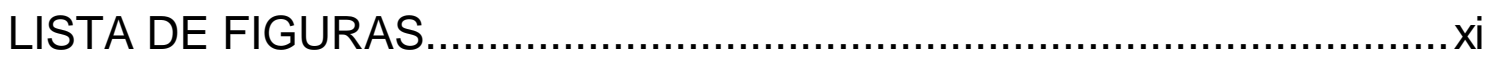

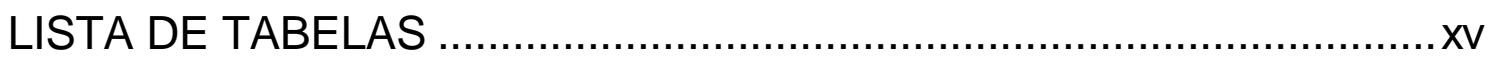

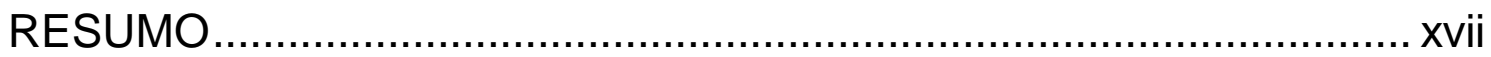

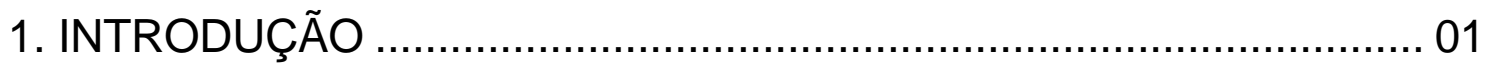

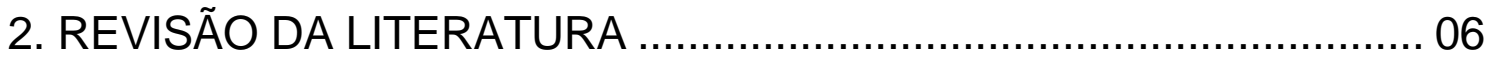

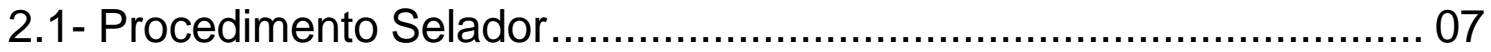

2.2- Propriedade de desgaste ............................................................ 30

2.3- Propriedade de Rugosidade.......................................................... 48

2.4- Relação entre Rugosidade Superficial e Placa Dentária................... 51

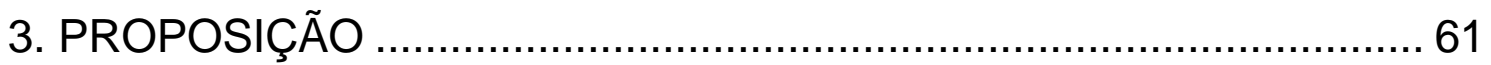

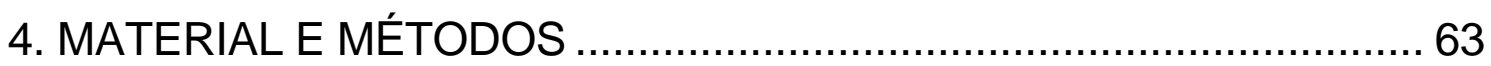

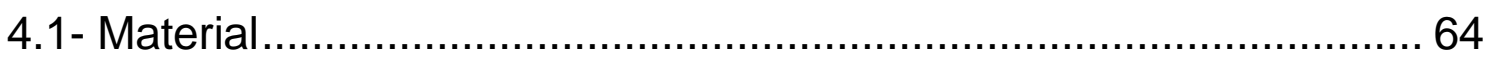

4.1.1- Cimentos de ionômero de vidro ................................................... 64

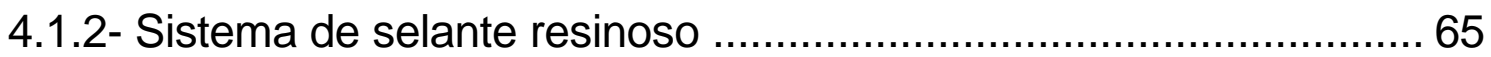

4.1.3- Silicona industrial e resina acrílica, liga metálica ......................... 65

4.1.4- Tiras de poliester e lâminas de vidro ............................................ 66

4.1.5- Esmalte de unha incolor e finishing gloss ................................... 66

4.1.6- Sonda exploradora e pinça clínica .............................................. 67

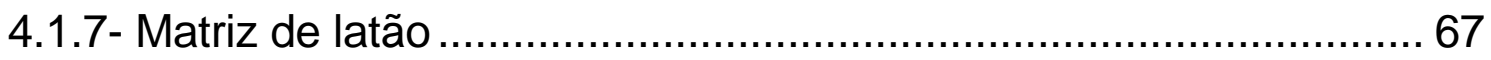

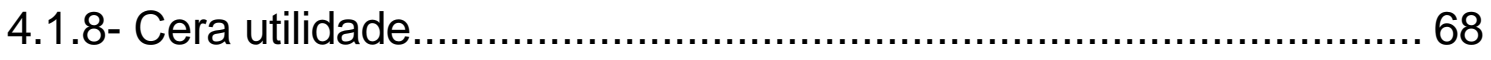

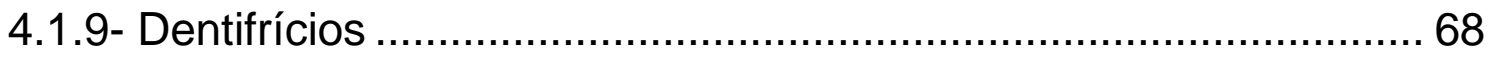

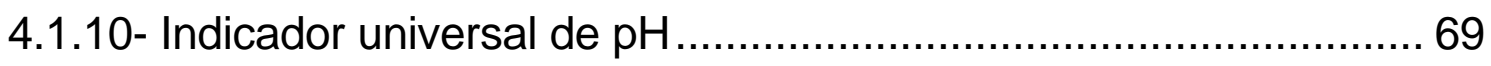

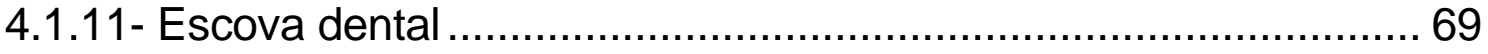

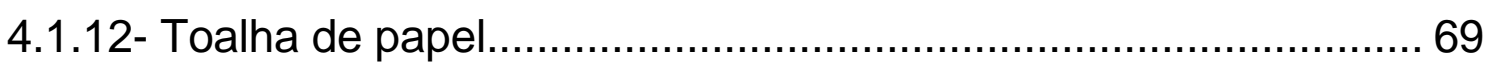

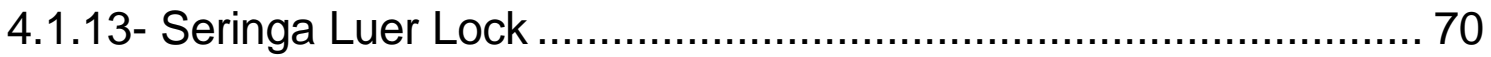

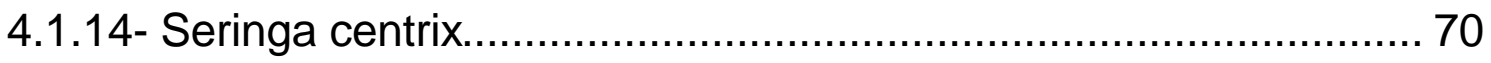

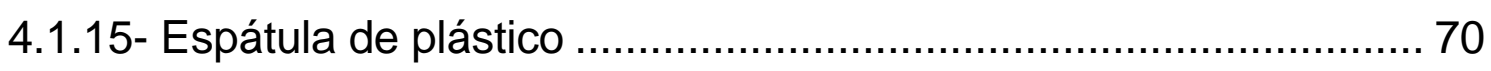

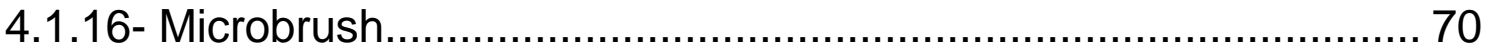


4.1.17- Aparelho fotopolimerizador ................................................ 71

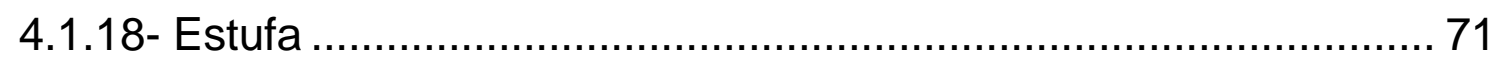

4.1.19- Balança eletrônica ..................................................................... 71

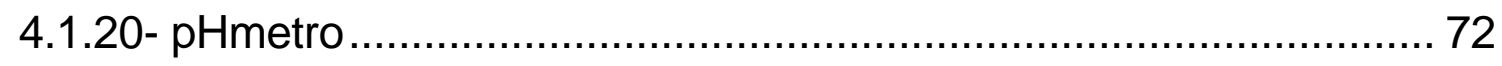

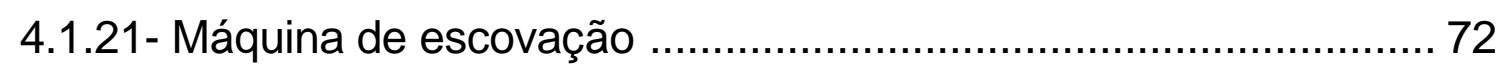

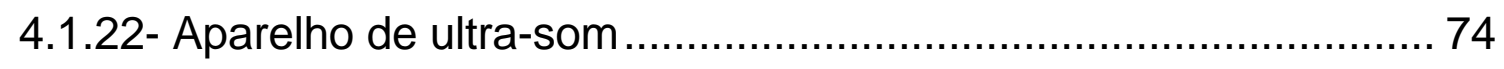

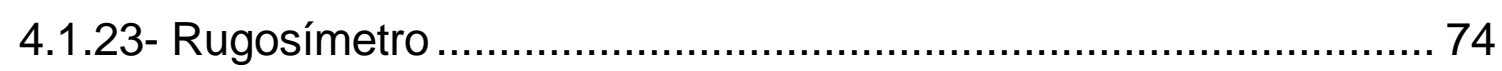

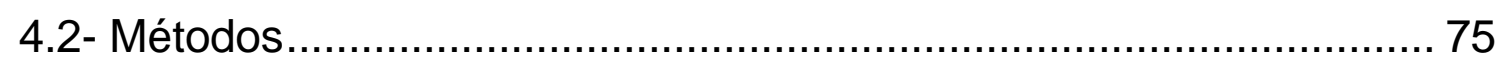

4.2.1- Confecção dos corpos de prova................................................ 75

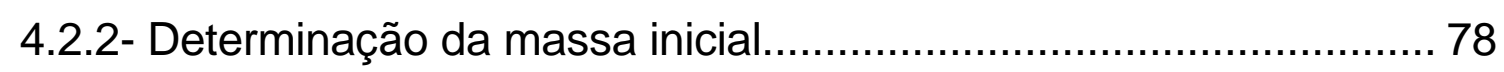

4.2.3- Procedimentos de desgaste .................................................... 78

4.2.4- Limpeza dos corpos de prova ................................................. 80

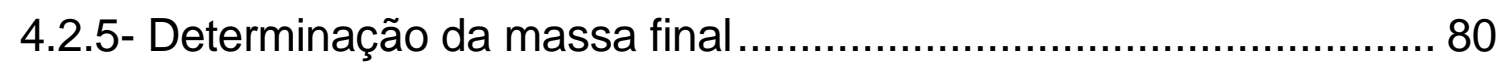

4.2.6- Avaliação da rugosidade superficial........................................... 81

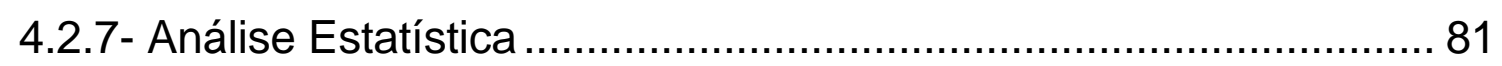

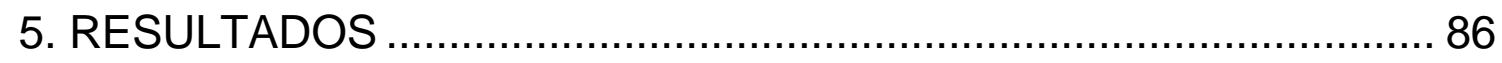

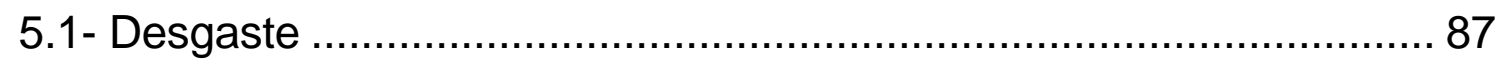

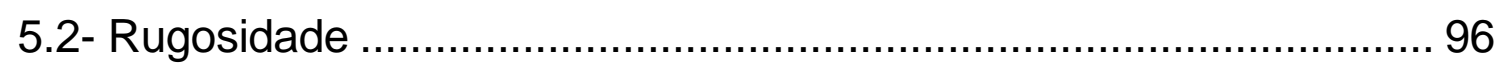

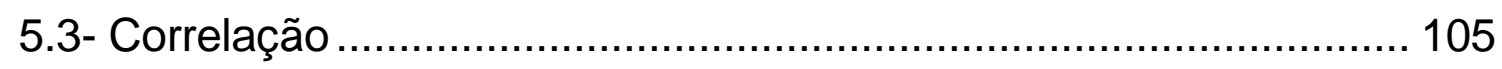

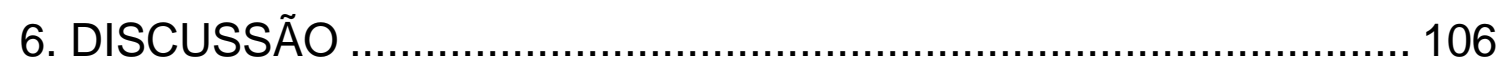

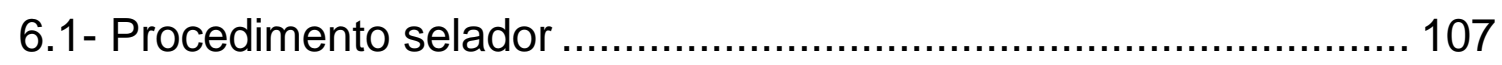

6.2- Propriedade de desgaste ........................................................ 115

6.3- Propriedade de rugosidade ...................................................... 117

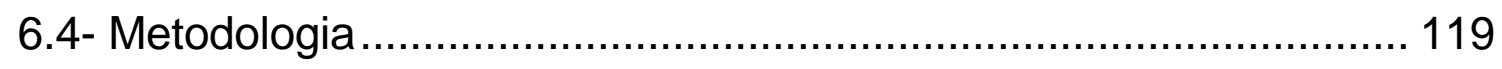

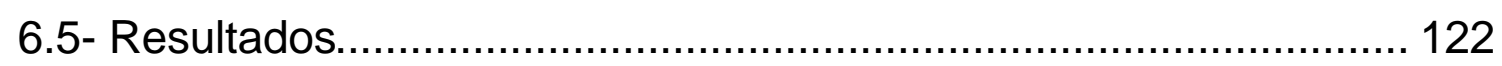

7. CONCLUSÕES ...................................................................... 130

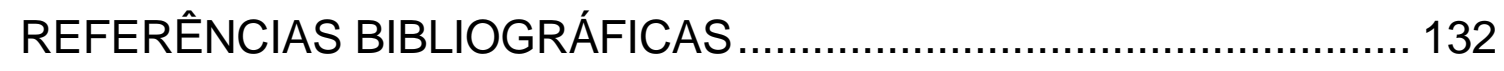

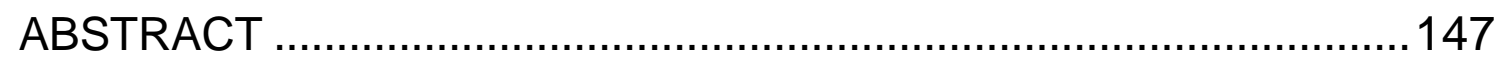




\section{LISTA DE FIGURAS}

FIGURA 1- Apresentação comercial dos Cimentos de lonômero de Vidro pesquisados, respectivamente: GC Fuji Plus, Ketac Molar e Vitremer. 82

FIGURA 2- Apresentação comercial do selante resinoso, Delton, utilizado como controle.

FIGURA 3- Molde destinado à confecção dos corpos de prova. 82

FIGURA 4- Tira de poliéster e lâmina de vidro, materiais auxiliares na confecção dos corpos de prova 82

FIGURA 5- Esmalte de unha incolor e Finishing Gloss, protetores ionoméricos utilizados 82

FIGURA 6- Recipiente da máquina de escovação, matriz de latão, tira de cera utilidade e corpos de prova.

FIGURA 7- Posicionamento dos materiais da Figura 6 para realização do teste de escovação 83

FIGURA 8- Apresentação comercial do dentifrício Sorriso. 83

FIGURA 9- Dentifrício Sorriso diluído 83

FIGURA 10- Apresentação comercial do dentifrício Tandy. 83

FIGURA 11- Dentifrício Tandy diluído. 83 
FIGURA 12- Apresentação comercial da escova dental.

FIGURA 13- Aparelho fotopolimerizador Optilight 600 e radiômetro da Gnatus . 84

FIGURA 14- Balança eletrônica de precisão, Mettler Toledo, modelo AB 204.Utilizada para pesar os corpos de prova. 84

FIGURA 15- Rugosímetro Hommel Tester T 1000, ponta apalpadora percorrendo o corpo de prova para medição da rugosidade.

FIGURA 16- Rugosímetro Hommel Tester T 1000, visor e unidade de processo das informações. 84

FIGURA 17- Máquina de escovação. 85

FIGURA 18- Vista lateral de um dos seis dispositivos da máquina onde os corpos de prova foram submetidos ao teste de escovação. 85

FIGURA 19- Vista frontal de um dos seis dispositivos da máquina onde os corpos de prova foram submetidos ao teste de escovação. 85

FIGURA 20- Gráfico comparando as médias das massas inicial e final dos materiais testados utilizando dois diferentes dentifrícios (Sorriso e Tandy). 
FIGURA 21- Gráfico comparando a média da porcentagem de desgaste dos materiais utilizando dois diferentes dentifrícios (Sorriso e Tandy).

FIGURA 22- Gráfico da comparação entre as médias da porcentagem de desgaste dos materiais utilizando o dentifrício Tandy. 95

FIGURA 23- Gráfico da comparação entre as médias da porcentagem de desgaste dos materiais utilizando o dentifrício Sorriso. 95

FIGURA 24- Gráfico comparando as médias de rugosidade dos materiais testados antes e após escovação utilizando dois diferentes dentifrícios (Sorriso e Tandy). 96

FIGURA 25- Gráfico comparando as médias de diferença de rugosidade dos materiais utilizando dois diferentes dentifrícios (Sorriso e Tandy).

FIGURA 26- Gráfico da comparação entre as médias das diferenças de rugosidade dos materiais utilizando o dentifrício Sorriso 104

FIGURA 27- Gráfico da comparação entre as médias das diferenças de rugosidade dos materiais utilizando o dentifrício Tandy. 105

FIGURA 28- llustração da conseqüência da aplicação inadequada dos selantes resinosos. 
FIGURA 29- Ilustração do processo de desgaste dos C.I.V. 123 


\section{LISTA DE TABELAS}

TABELA 1- Cimentos de lonômero de Vidro pesquisados.

64

TABELA 2- Selante Resinoso utilizado como controle. 65

TABELA 3- Dentifrícios utilizados 68

TABELA 4- Divisão dos grupos e informações necessárias para confecção dos corpos de prova. 75

TABELA 5- Massa inicial $\left(M_{1}\right)$, massa final $\left(M_{2}\right)$, diferença $\left(M_{1}-M_{2}\right)$, em gramas e percentagem de perda de massa para 0 selante resinoso Delton

TABELA 6- Massa inicial $\left(M_{1}\right)$, massa final $\left(M_{2}\right)$, diferença $\left(M_{1}-M_{2}\right)$, em gramas e percentagem de perda de massa para 0 cimento de iônomero de vidro Ketac Molar. 89

TABELA 7- Massa inicial $\left(M_{1}\right)$, massa final $\left(M_{2}\right)$, diferença $\left(M_{1}-M_{2}\right)$, em gramas e percentagem de perda de massa para 0 cimento de iônomero de vidro GC Fuji Plus. 90

TABELA 8- Massa inicial $\left(M_{1}\right)$, massa final $\left(M_{2}\right)$, diferença $\left(M_{1}-M_{2}\right)$, em gramas e percentagem de perda de massa para 0 cimento de iônomero de vidro Vitremer.

TABELA 9- Massa inicial $\left(M_{1}\right)$, massa final $\left(M_{2}\right)$, diferença $\left(M_{1}-M_{2}\right)$, em gramas e percentagem de perda de massa para 0 cimento de iônomero de vidro Vitremer Diluído 1/4 
TABELA 10-Porcentagem média da perda de massa e desvio padrão dos grupos estudados.

TABELA 11- Comparações individuais pelo método Tukey entre as médias obtidas dos percentuais de perda após os testes de escovação

TABELA 12- Rugosidade média $(u m)$ inicial, final e diferença entre elas para os corpos de prova do material Delton.

TABELA 13- Rugosidade média (um) inicial, final e diferença entre elas para os corpos de prova do material Ketac Molar. 98

TABELA 14- Rugosidade média ( $\mu \mathrm{m})$ inicial, final e diferença entre elas para os corpos de prova do material GC Fuji Plus. 99

TABELA 15- Rugosidade média ( $u$ m) inicial, final e diferença entre elas para os corpos de prova do material Vitremer. 100

TABELA 16- Rugosidade média (um) inicial, final e diferença entre elas para os corpos de prova do material Vitremer Diluído $1 / 4$. 101

TABELA 17-Porcentagem média da diferença de rugosidade e desvio padrão dos grupos estudados.

TABELA 18- Comparações individuais pelo método Tukey entre as médias obtidas das diferenças de rugosidade após os testes de escovação 
RESUMO 


\section{RESUMO}

O presente estudo foi conduzido "in vitro" com o intuito de constatar algumas das propriedades (desgaste e rugosidade) dos CIV (cimento de ionômero de vidro), as quais influenciam na sua indicação como material selador de fossas e fissuras. Simultaneamente avaliaram-se a abrasividade de dois dentifrícios (Tandy e Sorriso) e a influência destes sobre a lisura de superfície dos selantes. Os materiais empregados foram Fuji Plus (CIV cimentante), Ketac-Molar e Vitremer (ambos CIV restauradores). Este último material foi utilizado em duas proporções: na recomendada pelo fabricante (1:1) e na forma experimentalmente diluída (1/4:1). O selante resinoso Delton, sem carga e quimicamente ativado, foi utilizado como controle. A determinação do desgaste foi obtida através da quantidade de massa perdida após a escovação, utilizando-se uma balança eletrônica de precisão, em grupos de 12 corpos de prova de cada material com ambos dentifrícios. A rugosidade foi determinada pela análise quantitativa da superfície destes corpos de prova através de um aparelho medidor (rugosímetro), comparando a diferença de rugosidade após os testes de escovação. Os resultados foram submetidos à análise de variância a dois critérios e ao teste de Tukey $(\mathrm{p}<0.05)$. A abrasividade do dentifrício Tandy foi semelhante à do Sorriso nos cinco grupos de materiais testados, sendo Vitremer diluído e Fuji Plus os que possuíram o maior grau de desgaste. A 
rugosidade resultante da escovação com o dentifrício Sorriso nos grupos Vitremer diluído e Fuji Plus, foi maior comparada ao Tandy enquanto nos outros grupos a ação dos dentifrícios foi semelhante. O material que apresentou maior aumento de rugosidade foi o Vitremer diluído, os outros apresentaram resultados estatisticamente equivalentes, com exceção do Fuji Plus, que mostrou a segunda maior rugosidade quando submetido ao dentifrício Sorriso. Apesar de clinicamente se encontrar um maior uso dos cimentos ionoméricos cimentantes ou diluídos como forma alternativa para material selador; este trabalho permitiu concluir que "in vitro" estes possuem propriedades bastante inferiores quando comparados aos ionômeros restauradores que, por sua vez, possuem resultados semelhantes ao selante resinoso utilizado como controle. 
1. INTRODUÇÃO 


\section{INTRODUÇÃO}

$\mathrm{Na}$ atualidade, a tendência principal e mais importante na Odontologia, é o estabelecimento de medidas preventivas efetivas ${ }^{12}$.

Com o intuito de promover a prevenção da cárie na região de fossas e fissuras, instaurou-se o procedimento de selamento ${ }^{9,10,14,87}$, que constitui na colocação de um material específico a base de resina, formando uma película contínua e resistente que, quando perfeitamente adaptada e retida, é capaz de fornecer uma barreira mecânica que impede 0 acúmulo de placa dentária e concomitantemente permite uma melhor higienização ${ }^{10,36,4647}$. O material padrão para realização deste procedimento é o selante resinoso ${ }^{14,37}$, no entanto, a partir de 1974 , McLEAN e WILSON ${ }^{61}$ introduziram o uso do cimento de ionômero de vidro (CIV) como selante, por ser um material com boas propriedades, entre as quais a liberação de flúor ${ }^{15,16,17,26,74}$. Desde então, vários trabalhos foram feitos a fim de verificar sua eficiência, na maioria das vezes medida pela retenção do material ${ }^{59,77,90,106,109}$.

A partir do final da década de 80 com a introdução do CIV modificado por resina ${ }^{56}$, foram viabilizadas melhorias de algumas limitações inerentes aos CIV convencionais principalmente em relação 
à sensibilidade a sinérise e embebição, preservando contudo, a capacidade de liberação de flúor e possibilitando melhor manipulação ${ }^{56,57}$. Além de tornar viável o condicionamento ácido do esmalte para aumentar a retenção do selante ionomérico ${ }^{76,101}$. Desta forma, passou-se a contar com mais um tipo de material para o selamento de fossas e fissuras ${ }^{48,65,83}$.

Ainda hoje na literatura há divergência entre os resultados quanto à retenção, porém com relação à sua ação positiva na diminuição de cáries os dados obtidos são concordantes ${ }^{31,42,61,83,89,108}$. A justificativa encontrada para este comportamento do cimento de ionômero de vidro foi o seu modo de ação que atua de maneira diferente do selante resinoso. O CIV apesar de possuir uma menor retenção, permanece como um tampão no fundo da fissura, além de liberar flúor às estruturas adjacentes ${ }^{4,5,25,89}$ e atuar como sua fonte de reserva graças à capacidade de incorporação dos íons flúor provenientes dos diferentes veículos fluoretados que tramitam no meio bucal ${ }^{27}$, evitando assim a instalação e progressão de processos cariosos $^{105}$.

O comportamento clínico dos CIV está alicerçado em diversos fatores, sendo a resistência ao desgaste um deles ${ }^{65,70,111}$. O desgaste, embora termo familiar, é de fato difícil de ser definido e geralmente é aceito como sendo uma remoção gradual de material resultante da 
interação entre superfícies ${ }^{20}$. A ocorrência deste fenômeno pode advir de processos de escovação, de contatos na mastigação e de abrasão por substâncias utilizadas na alimentação ${ }^{16,18,21,22,35}$.

Os materiais utilizados para o selamento de fossas e fissuras, normalmente aplicados em áreas em que não há contato da face oclusal, estão sujeitos predominantemente ao fenômeno da abrasão resultante da aplicação da escova dental-dentifrício e da oclusão ${ }^{65,67}$.

No que se refere ao desgaste pela interação escova dentaldentifrício, a severidade com que este ocorre está relacionada à constituição das partículas abrasivas que compõem os dentifrícios, ao tipo de cerdas da escova e ao vigor e freqüência de realização da escovação, além dos padrões diversos de abrasão dos materiais em decorrência de sua dureza e do tamanho, forma e espaçamento entre as partículas de carga que os constitui ${ }^{1,18,41}$.

Apesar da importância das medidas com flúor e selantes citadas anteriormente, não se deve omitir a necessidade da higiene bucal como um dos principais métodos de prevenção $^{12}$. Uma escovação adequada é imprescindível à partir do momento que alia a ação química por meio do dentifrício fluoretado com a ação mecânica de remoção da placa. Paradoxalmente, a ação da escovação pode resultar em rugosidade na superfície do material selador, facilitando desta forma a adesão e retenção de placa dentária ${ }^{75,78,96,97}$. 
Considerando que em crianças a fase crítica para o acúmulo de placa na face oclusal ocorre na etapa de erupção dentária e sendo a aplicação do selante um dos meios de solucionar este problema $^{19,43,44,45}$, vamos nos ater a avaliar a intensidade em que ocorre a ação da escova dental/dentifrício sobre os materiais, já que este é o principal responsável pelo desgaste neste momento.

A importância da escovação, utilizando-se diferentes dentifrícios, e do selamento com a ocorrência de uma relação de causa e efeito entre eles, despertou a idealização do presente estudo, que avaliou in vitro o comportamento, quanto ao desgaste e conseqüente rugosidade, dos diferentes tipos de cimentos de ionômero de vidro utilizados como selante e um selante resinoso, quando submetidos à escovação simulada, com diferentes dentifrícios. 
2. REVISÃO DA LITERATURA 


\section{REVISÃO DA LITERATURA}

\section{1- Procedimento Selador}

Estudos epidemiológicos mostram que nos últimos vinte anos as cáries declinaram, em crianças e adolescentes, na maioria dos países industrializados, mas em muitas das nações em desenvolvimento, ainda há um índice muito alto da doença ${ }^{73,68}$.Após a introdução do flúor na água de abastecimento e posteriormente a difusão de sua aplicação tópica, houve uma mudança nas características da cárie dentária, ocorrendo menos lesões em áreas de superfícies lisas, devido a uma maior proteção propiciada pelo flúor, quando comparadas às lesões em fossas e fissuras ${ }^{68,73,82}$.

Já no inicio do século XX HYATT $^{45}$ e BODECKER $^{8}$ demonstraram uma maior preocupação com a região de fossas e fissuras e preconizaram respectivamente, a técnica da odontomia profilática seguida da restauração com amálgama e a erradicação mecânica das fissuras ${ }^{45}$.

Somente com o advento da técnica do condicionamento ácido proposta por Buonocore ${ }^{9}$ em 1955 foi que o selamento das fossas e fissuras começou a ser considerado como um mecanismo preventivo na Odontologia ${ }^{14}$. 
Entretanto, só em 1965 foram apresentados os primeiros trabalhos com resultados clínicos usando a técnica de selamento de superfícies oclusais por CUETO e BUONOCORE. O estudo baseouse numa comparação clínica entre 2 tipos de selantes. O cianocrilato foi o primeiro agente usado nos testes para selar fossas e fissuras, sendo polimerizado por luz ultravioleta, no entanto sua difícil manipulação e necessidade de reaplicações constantes, devido à sua decomposição no meio bucal, tornaram-no inadequado para o uso bucal prolongado. Igualmente os selantes à base de poliuretano não apresentaram características retentivas para selar fossas e fissuras oclusais por um longo período de tempo ${ }^{38}$. Foi então que em 1970, BUONOCORE ${ }^{10}$ publicou um trabalho usando um selante à base de Bis-GMA, produto da reação do bisfenol A com glicidil metacrilato. Após um ano de testes, dos 200 dentes selados, 195 apresentavam o selante em excelentes condições; quatro dentes estavam em boas condições e apenas um dente apresentava perda parcial do selante. No grupo controle, $42 \%$ dos dentes apresentaram-se cariados após o primeiro ano.

A química dos selantes de Bis-GMA é essencialmente igual à da resina composta, no entanto os materiais seladores resinosos devem ser mais fluidos para penetrar nas fissuras e nas áreas de esmalte condicionadas por ácido, dando retenção ao selante ${ }^{82,85}$. 
Desde o seu surgimento até o final da década de 80 , o selante resinoso teve sua hegemonia estabelecida, não havendo outra opção viável de um material que pudesse ser utilizado com esta finalidade $\mathrm{f7}^{47,68,105}$.

No entanto, no início da década de 70 , mais precisamente em 1972, WILSON e KENT ${ }^{110}$ introduziram o cimento de ionômero de vidro (CIV), material oriundo do cimento de silicato que tem como principal propriedade a liberação de flúor ${ }^{24,95}$.

Nesta formulação, o cimento de ionômero de vidro constitui-se basicamente de um pó de vidro básico e um poliácido, que reagem entre si, dando origem a um sal. O pó é preparado através da fusão dos componentes sílica $\left(\mathrm{SiO}_{2}\right)$, alumina $\left(\mathrm{Al}_{2} \mathrm{O}_{3}\right)$ e fluoreto de cálcio $\left(\mathrm{CaF}_{2}\right)$, entre 1100 e $1500^{\circ} \mathrm{C}$, e posterior resfriamento e desgaste até

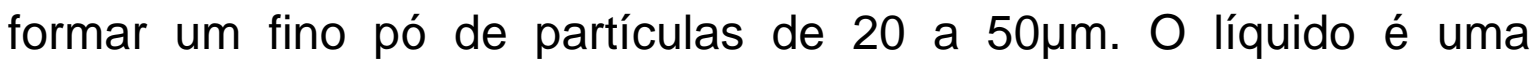
solução aquosa de ácido poliacrílico a 40-50\%, com ácido tartárico (acelerador de presa que não interfere no tempo de trabalho) e ácido itacônico (diminui a viscosidade) ${ }^{69,74}$.

A reação de presa ácido-base dos cimentos convencionais ocorre da seguinte forma: o íon hidrogênio do poliácido ataca a superfície externa das partículas de vidro, liberando os íons metálicos $\mathrm{Al}^{+++}$e $\mathrm{Ca}^{++}$que migram para a fase aquosa do cimento. O cálcio reage com as cadeias aniônicas do poliácido, formando poliacrilato de 
cálcio e dando origem à uma matriz de gel. Assim sendo, a porção mais externa das partículas de vidro, correspondentes aos íons metálicos, reagem com o ácido e se transformam em gel, e as porções da partícula não reagidas atuam como carga da matriz gel de polissais ${ }^{16}$. Com a formação da matriz de polissais o cimento endurece. Mais lentamente, o alumínio liberado vai reagindo, formando poliacrilato de alumínio, proporcionando a maturação da matriz, que pode durar meses ${ }^{17,16,26}$. A água apresenta um importantíssimo papel na reação de presa pois é o meio de transporte dos íons, permitindo que ocorram as trocas iônicas ${ }^{16,26,70}$. Os cimentos de ionômero de vidro de um modo geral devem ser protegidos do contato precoce com água através de algum agente protetor que permaneça em torno de 24 horas, como esmalte de unha incolor, resina fluida ou verniz fornecido pelo fabricante, prevenindo a sinérese e embebição durante as primeiras etapas da reação do material ${ }^{70}$.

A partir desta primeira formulação outras foram surgindo ao longo dos anos, havendo atualmente três tipos de CIV para uso em Odontologia, sendo eles: CIV convencional, CIV modificado por partículas metálicas e CIV modificado por resina.

TAY; LYNCH sugeriram a classificação dos cimentos de ionômero segundo sua indicação; sendo materiais do Tipo I, para cimentação, do Tipo II para restauração, do tipo III, para revestimento 
e do Tipo IV, os materiais fotoativados. A American Dental Association (ADA) estabeleceu uma classificação quanto a composição, dividindo-os em: cimentos convencionais, cimentos anidros, cermets e cimentos modificados por resina ${ }^{70}$.

A produção de um material híbrido de ionômero de vidro e resina composta contendo flúor e capaz de aderir-se aos tecidos dentais foi proposta em estudos realizados por MATHIS; FERRACANE $^{56}$. Efetuou-se uma mistura do líquido de um ionômero restaurador comercial (Fuji II), com uma resina experimental fotopolimerizável, semelhante à usada nos compósitos dentais. O líquido híbrido obtido foi misturado ao pó de ionômero de vidro, produzindo um material com significante melhoria nas propriedades mecânicas, baixa solubilidade em água, e baixa sensibilidade à umidade. A adesão desse material aos tecidos dentais mostrou-se semelhante a do cimento ionomérico convencional.

Nos cimentos de vidro modificados por resina, devido a incorporação de um percentual de HEMA ou BIS-GMA ao líquido do cimento de ionômero, além da reação ácido-base, ocorre também a fotopolimerização dos radicais resinosos. A luz ativa o acelerador presente no pó, produzindo radicais livres, e os grupamentos metacrilato terminais do líquido se polimerizam. Como uma porção da água é substituída pelos monômeros, a reação ácido-base nos 
cimentos modificados por resina ocorre mais lentamente, permitindo que 0 operador controle 0 tempo de trabalho através da fotopolimerização da porção resinosa $a^{54,57,70}$. Alguns cimentos de ionômero de vidro, apresentam tripla presa: reação ácido-base, fotopolimerização dos radicais da resina e polimerização química da resina $^{70}$.

Entre as principais indicações do cimento de ionômero de vidro na Odontopediatria podemos citar o selamento de fossas e fissuras de dentes posteriores decíduos e permanentes ${ }^{71}$.

Considerando principalmente a capacidade de liberação de flúor deste material, CRISP; LEWIS; WILSON ${ }^{62,}$ em 1976, investigaram as conseqüências da variação nas proporções pó/líquido no efeito químico de erosão da água em cimentos de ionômero de vidro. Dois materiais foram utilizados, ASPA I e ASPA II, com consistências diferentes de cimentação e restauração, houve variação com relação ao instante de colocação dos corpos na água, logo depois de sua confecção (curta presa) ou após 24 horas (longa presa). A análise química dos eluentes foi feita através de técnicas padronizadas. Devido à existência de materiais solúveis no ionômero, foi demonstrada ocorrência máxima dos eluentes na fase de formação do cimento e dois processos podem ser responsáveis pela remoção das entidades solúveis: a reação química formadora de produtos 
insolúveis ou a difusão para fora pela ação de um solvente. O cálcio e o alumínio são íons utilizados na reação química do CIV e os íons flúor são eliminados como um complexo metálico fluoretado decomposto durante a reação de formação do cimento e posteriormente são removidos por um processo de difusão. Os resultados mostraram saída de cálcio apenas nas amostras de curta presa, confirmando que na reação inicial esses íons são rapidamente aderidos, sob a forma insolúvel, às cadeias de poliacrilato. A saída de alumínio confirmou a formação mais lenta do poliacrilato de alumínio na matriz em relação ao sal de cálcio. Com relação aos íons flúor, há uma diminuição de sua saída com o tempo mas não houve indicações de que ela cesse. A sílica se encontrava presente na matriz como um gel de sílica na superfície de partículas de vidro reagidas. A quantidade de saída de íons foi maior nos CIV diluídos. Houve adesão de água à estrutura do ionômero, e a absorção dessa água só ocorreu na primeira semana. Observou-se uma diminuição da saída de eluentes ao aguardar a longa presa (24 horas) para submeter o material à erosão em água.

Devido à ocorrência de dúvidas relacionadas aos fatores que poderiam afetar a liberação de flúor dos cimentos ionoméricos, CRANFIELD; KUHN; WINTER ${ }^{15}$, em 1982, realizaram um estudo utilizando quatro materiais, Chembond, ASPA, Fuji I e Fuji II. Os 
corpos de prova confeccionados foram submetidos à contagem de liberação de flúor durante 13 semanas através de eletrodos. O efeito da proporção pó/líquido foi analisada no ASPA 3:1 e 2:1, e após 28 dias o material diluído apresentou uma maior liberação de flúor. A diminuição do $\mathrm{pH}$ aumentou a liberação de flúor em todos materiais testados, e a mudança na forma dos corpos de prova influenciou a liberação. Os autores concluíram que a natureza da liberação de flúor ainda não foi estabelecida e existe controvérsia a respeito, entre os pesquisadores, na literatura.

O fenômeno de erosão na boca, onde existem ácidos orgânicos e eletrólitos inorgânicos é diferente da erosão em água destilada. Para esclarecer o mecanismo de erosão dos cimentos de ionômero de vidro FUKAZAWA; MATSUYA; YAMANE ${ }^{32}$ (1987) os submeteram a uma solução ácida sob várias condições. As quantidades de $\mathrm{F}, \mathrm{Al}, \mathrm{Si}$ e Ca liberadas do cimento foram: proporcional ao tempo de imersão, não relacionadas com a forma ou volume dos corpos de prova, dependiam da área de superfície dos corpos e não eram afetadas pela agitação da solução. O endurecimento do cimento é composto de duas fases estruturais: partículas de vidro não reagidas embebidas em uma matriz gel contendo policarboxilato e complexos de flúor, estudos anteriores relataram a existência de grupos $\mathrm{COOH}$ presentes na matriz do cimento com menos de 24 horas de idade, devido à 
reação com $\mathrm{Al}^{\beta+}$ ser demorada. Nesse período se o material for imerso a solução penetrará nele pela superfície e expandirá a matriz gel, e dependendo da concentração de $\mathrm{H}^{+}$poderá reagir com os cátions metálicos os difundindo para fora da matriz. Apesar da maturação da matriz gel dificultar a difusão dos elementos, devido a reação dos CIV continuar por um longo período, a matriz pode sofrer alterações, explicando o fato da maior idade do cimento interferir em uma menor perda de AL, F e Si. Foi concluído que a dissolução era controlada pela difusão desses elementos da matriz, influenciada pela estrutura da matriz e pela concentração do íon $\mathrm{h}^{+}$na superfície do cimento. As partículas de vidro não reagidas próximas à superfície do ionômero foram dissolvidas pela longa imersão, e muitos poros foram deixados na superfície da região.

$\mathrm{KOCH}$; HATIBOVIC-KOFMAN ${ }^{49}$ conduziram estudos complementares de liberação de flúor pelos CIV em 1990. Os materiais utilizados foram Vitrebond, Ketac-Fil e ChelonFil II, na investigação "in vivo", analisaram a liberação de flúor e presença de S. mutans na saliva por um ano após a restauração de dentes com material ionomérico. A concentração de flúor na saliva foi de 0,04ppm antes das restaurações, 0,8ppm após três semanas e se manteve constante com $0,3 p p m$ até um ano. A prevalência de $S$. mutans na saliva diminuiu após a colocação do ionômero restaurador. No estudo 
"in vitro" os corpos de prova foram colocados em água deionizada e a liberação foi medida semanalmente por 16 semanas. Na décima segunda semana, as amostras foram expostas à pasta fluoretada. Concluiu-se que os cimentos ionoméricos podem atuar como um recarregador vagaroso de flúor, pois mostraram uma capacidade de absorção de flúor da pasta e sua posterior liberação. Os autores encontraram uma maior capacidade de liberação de flúor do Vitrebond, uma composição entre CIV e resina, e afirmaram que esse fenômeno ocorreu devido a liberação ser resultante da composição dos materiais.

DAVIES; SEFTON; WILSON ${ }^{17}$, em 1993, estudaram os fatores que poderiam influenciar a liberação de flúor por três cimentos de ionômero de vidro, Legend, Chemfil II e Fuji II. Foram examinados o efeito da maturidade do ionômero (10 minutos e 24 horas após a mistura) no momento da imersão e a proporção pó/líquido (proporção do fabricante- $R_{1}$ e diluída- $\left.R_{2}=0,70 R_{1}\right)$. Concluíram que a liberação depende do grau de maturidade do cimento ao ser imerso em água, e este pôde ser correlacionado com a taxa de seu endurecimento, quanto mais imaturo (10 min.) maior a liberação de flúor e menor resistência à compressão. Além disso, quando o material se encontra imaturo, a liberação depende da composição química e da relação de pó e líquido, e quando é submerso em água se torna 
permanentemente debilitado e a área de superfície aumenta devido a erosão e rugosidade. No entanto, quando o ionômero se encontra maduro (24 horas) o efeito da proporção $\mathrm{P} / \mathrm{L}$ na liberação é estatisticamente insignificante, sendo que a liberação do flúor se torna menos dependente do material.

Em 1999 YIP; LAM; SMALES ${ }^{111,112}$ publicaram dois estudos semelhantes investigando a liberação de flúor, a perda de peso e o desgaste erosivo de três CIV convencionais (Fuji IX, ChemFil Superior, Ketac-Silver), três modificados por resina (Fuji II LC, Vitremer, Photac-Fil), um compômero e uma resina composta foi usada como controle (Z100). A quantidade de liberação de flúor e a mudança de peso foram medidas por 12 semanas, e posteriormente os corpos de prova foram submetidos a um recarregamento de flúor com $2 \mathrm{ml}$ de flúor fosfato acidulado a 1,23\%, e novamente medidos por 12 semanas. No final do estudo, os corpos de prova foram examinados através de microscópio eletrônico de varredura e a rugosidade $\left(R_{a}\right)$ medida utilizando-se um perfilometro. Todos os materiais, exceto a resina, apresentaram uma grande liberação de flúor nos dois primeiros dias, caindo bruscamente durante duas semanas tornando-se constante após a quinta semana. $O$ recarregamento com flúor causou um grande aumento na liberação de flúor para todos cimentos ionoméricos correlacionado a uma grande 
perda de peso. Os ionômeros modificados por resina apresentaram menor liberação de flúor e também menor perda de peso comparados aos convencionais. Todos os materiais sofreram um aumento em suas rugosidades. O efeito erosivo do flúor gel nas restaurações ionoméricas pode aumentar a colonização da superfície pela placa, e reduzir a longevidade da restauração.

Desde 1970 o selamento vinha sendo reconhecido, por vários autores $^{10,87,105}$, como procedimento relevante e eficaz na Odontologia Preventiva, baseados nisso, em 1974, McLEAN; WILSON ${ }^{61}$ introduziram o uso do cimento de ionômero de vidro (ASPAll) como selante, recomendando seu uso em fossas e fissuras com largura superior a cem microns. Em estudo clínico com duração de 2 anos, utilizando-se 279 dentes posteriores em pacientes de 9 a 16 anos, houve uma alta porcentagem de sucesso, no primeiro ano $10 \%$ e no segundo apenas $4 \%$ dos selantes foram completamente perdidos, relatando-se estabilidade da forma anatômica, adaptação marginal e ausência de cárie nas fissuras restauradas. Os resultados mostraram um decréscimo significativo no índice de falhas do selante, indicando que na maioria dos casos, o tratamento é duradouro não necessitando ser repetido .

Desde então, vários estudos têm sido realizados com intuito de demonstrar sua efetividade como selante de fossas e fissuras ${ }^{62,103,65}$, 
provavelmente em função da sua capacidade de adesão à estrutura mineralizada do dente e da habilidade em liberar e absorver flúor, acarretando uma diminuição das cáries secundárias e protegendo as superfícies de esmalte adjacentes ${ }^{29}$, no entanto há uma grande divergência entre os resultados encontrados, devido a diferentes utilizações de metodologias, procedimentos clínicos e materiais.

SHIMOKOBI et al $^{104}$. avaliaram clinicamente o comportamento de um ionômero especialmente formulado para selamento, pela G-C Dental Corporation, comparado a um selante resinoso, Delton, utilizando como grupo controle molares inicialmente hígidos e sem tratamento. A incidência de cárie em dentes selados com CIV e Delton foi, respectivamente: $4,9 \%$ e $3,6 \%$ após seis meses; $14,6 \%$ e $10,7 \%$ após um ano; $37,6 \%$ e $25 \%$, após dois anos e 61,15 e 43,2\% após três anos. Apesar de não ter sido observada a presença do selante ionomérico a partir do sexto mês, comparada à retenção total do selante resinoso até o terceiro ano de controle, sua porcentagem de eficiência foi de $44 \%$ após dois anos em relação aos dentes não tratados, sugerindo uma prevenção à cárie mesmo após seu desaparecimento.

McKENNA; GRUNDY ${ }^{59}$, em 1987, estudaram o comportamento de um cimento ionomérico, Ketac-Fil, aplicado em 232 primeiros molares permanentes livres de cárie, por auxiliares odontológicos com 
prévio treinamento laboratorial. Após o período de seis meses, 93\% dos elementos examinados demonstraram retenção total do selante, 4,5\% retenção parcial e 2,5\% perda completa. Os resultados após 12 meses foram de $82,5 \%, 14 \%$ e $3,5 \%$ respectivamente. 0 índice de retenção do selante ionomérico, neste estudo, foi comparável aos obtidos com os selantes resinosos registrados em diversos trabalhos, além disso dos dentes que perderam parcialmente ou totalmente 0 selante, apenas dois desenvolveram cárie após um ano. Devido a sua propriedade de liberação de flúor, o selamento com cimento ionomérico seria favorável em dentes recém irrompidos cujo esmalte se encontra relativamente poroso.

Em 1990, em estudo clínico realizado por MEJÀRE; MJOR ${ }^{63}$ comparou os resultados obtidos através de observações clínicas com os de microscopia eletrônica de varredura das réplicas por impressões dos dentes, utilizando escores para registro da performance dos selantes. Apesar da perda total ter sido clinicamente diagnosticada nos selantes ionoméricos (Fuji III), nas réplicas foram observados restos do material no fundo das fissuras em $93 \%$ dos dentes e não se detectou cárie; em contrapartida clinicamente observaram-se $90 \%$ de retenção completa dos selantes a base de resina (Concise e Delton), sendo que nas réplicas essa retenção foi de apenas $58 \%$ e houve incidência de cárie em $5 \%$ dos dentes. Concluíram que existe a 
possibilidade de pequenas quantidades de selante de CIV serem suficientes para prevenir cáries em toda extensão de fissuras dos dentes.

OVREBO; RAADAL ${ }^{77}$, em 1990, investigaram a ocorrência de microinfiltração em fissuras seladas com dois materiais: o cimento ionomérico (Fuji III) e uma resina composta diluída (Concise). O selamento foi clinicamente efetuado em dez pares de pré-molares superiores contralaterais, livres de cárie, restaurações ou selamento prévio. Após 14 dias, os materiais foram examinados clinicamente quanto a sua integridade. Por razões ortodônticas, os elementos dentários foram extraídos, sendo preparados para avaliação quanto à penetração do corante azul de metileno a 0,5\%, após serem submetidos a procedimentos de termociclagem. Ficou demonstrado que o Fuji III apresentou pouca retenção clínica, sendo que dois selamentos se apresentaram totalmente ausentes e um apenas parcialmente. Ocorreu extensa infiltração do corante, tanto no interior do material quanto na interface dente/selante, logo o selamento com ionômero de vidro permite a infiltração mesmo estando totalmente retido. Já os compósitos não apresentaram perda ou infiltração. No entanto na avaliação microscópica verificou-se que remanescentes do cimento ionomérico permaneceram nas fissuras dos dentes com selamentos clinicamente ausentes, sendo provavelmente 
responsáveis pela prevenção da cárie em decorrência da liberação de flúor.

A resistência oclusal à desmineralização após a perda de selantes ionoméricos foi estudada "in vitro" utilizando-se o material Fuji Tipo III (G-C). Vinte e dois dentes humanos extraídos hígidos foram diretamente selados, 24 foram invadidos com broca diamantada e posteriormente selados e 25 foram controle, permanecendo sem tratamento. Após uma semana os selantes foram removidos tanto quanto possível através da utilização de uma sonda exploradora e os dentes submetidos à desmineralização por sete semanas. As profundidades das lesões nas fissuras foram mensuradas através do exame por meio de microscopia de luz polarizada. A média de desmineralização das fissuras controle foi de $143 \mu \mathrm{m}$, das fissuras naturais de $93 \mu \mathrm{m}$ e das fissuras invadidas de $75 \mu \mathrm{m}$. Os resultados demonstraram que as fissuras seladas com cimento de ionômero de vidro são mais resistentes à desmineralização do que o grupo controle mesmo depois da perda macroscópica do material, em função do efeito combinado entre liberação de flúor e permanência de resíduos de material na extremidade das fissuras ${ }^{89}$.

LOVADINO et $\mathrm{al}^{54}$. compararam clínica, radiografica e fotograficamente o desempenho, por 12 meses, do selante resinoso Delton e do cimento de ionômero de vidro Chelon-Fil, utilizados no 
selamento oclusal de 44 dentes hígidos e totalmente irrompidos. Verificaram-se $80 \%$ de retenção total do CIV e $33,33 \%$ do selante resinoso, no entanto ambos os materiais foram eficientes na manutenção de ausência de cárie da superfície oclusal e interproximal.

Em 1994 SUNDFELD, et $\mathrm{al}^{101}$. propuseram o selamento oclusal com ionômero de vidro fotopolimerizável, aplicado em esmalte dental condicionado pelo ácido fosfórico a $37 \%$ Os materiais empregados foram: Vitrebond, na proporção pó/líquido 1:1 além do Fuji II L.C. e do Variglass V.L.C., ambos na proporção 1:2. O estudo laboratorial foi realizado paralelamente ao estudo clínico de um ano, neste último foi observado excelente comportamento quanto à retenção na superfície oclusal, assim como, microscopicamente, houve penetração de numerosos e uniformes prolongamentos resinosos nos microporos do esmalte dental condicionado. Atribuíram-se a este fato os excelentes resultados de retenção obtidos. Os autores consideraram 0 condicionamento ácido do esmalte uma condição imprescindível para a retenção do material ao longo do tempo.

A retenção clínica dos selantes de ionômero de vidro em função do condicionamento ácido do esmalte foi avaliada por OLIVEIRA JúNIOR et al. ${ }^{76}$ em 1994. O Ketac-Cem, aplicado com prévio condicionamento do esmalte com ácido fosfórico a 37\% por 30 
segundos, demonstrou desempenho clínico semelhante ao grupo controle, selado com Delton. Já o mesmo material aplicado sem o prévio condicionamento do esmalte, após seis meses, apresentou apenas $9,55 \%$ dos selantes em condições de retenção clinicamente aceitáveis. O resultado observado entre o ionômero aplicado com e sem o prévio condicionamento ácido do esmalte apresentou diferença estatística, indicando que este procedimento aumentou efetivamente a retenção do material à superfície do dente; logo a utilização deste artifício retentivo ampliaria as indicações dos ionômeros preconizadas por Mc LEAN e WILSON ${ }^{96}$ para selamento oclusal apenas de fissuras com mais de cem $\mu \mathrm{m}$ de comprimento, permitindo sua aplicação também em dentes que não apresentem anatomia retentiva.

FORSS; SAARNI; SEPPA ${ }^{25}$ em estudo clínico de dois anos encontraram uma retenção de $26 \%$ para os CIV (Fuji III) aplicados para selar fossas e fissuras, $82 \%$ de retenção para os selantes resinosos (Delton) sendo que nenhuma diferença foi observada entre os materiais testados quanto à incidência de cárie nas superfícies seladas. Relataram que deveria haver diferença do mecanismo de prevenção entre os materiais para selante, assim a escolha pelos cimentos ionoméricos não se daria por sua retenção, e sim por outras propriedades como a liberação de flúor. 
Apesar do efeito anticariogênico dos selantes estar associado à sua retenção ${ }^{59,77,109}$, não é sempre necessário ao selante ionomérico exibir retenção completa pois sua eficácia não pode ser determinada apenas por essa propriedade, devendo-se considerar também o efeito do flúor após a perda do material selador ${ }^{5,77}$. Além disso, sua reaplicação é um procedimento viável e parece reduzir a incidência de cáries $^{50}$.

SIPHAHIER; ULUSU ${ }^{95}$, em 1995, em estudo laboratorial avaliaram o cimento ionomérico do tipo Cermet (Ketac-Silver), ou seja, CIV reforçado com partículas de prata, comparativamente ao selante resinoso (Delton) quanto a algumas propriedades mecânicas: resistência à compressão, resistência coesiva à tração e resistência ao desgaste. Com relação a esta última propriedade, 15 corpos de prova para cada material foram: confeccionados de acordo com as normas da ISO, mantidas em dissecador por 24 horas, pesados em balança eletrônica e posteriormente submetidos a teste de abrasão a dois corpos por 40 minutos. A porcentagem de desgaste foi calculada através da diferença entre a massa inicial e a final. $O$ desgaste do Ketac-Silver foi significativamente menor que o do Delton, no entanto, a resistência à compressão e à tração foi maior para o grupo do selante resinoso. Baseados nos resultados in vitro, os autores não consideram o ionômero Cermet como alternativa ao selante resinoso. 
No mesmo ano, os mesmos autores ${ }^{94}$ desenvolveram um estudo onde compararam o comportamento clínico do selamento de fossas e fissuras com os mesmos materiais (Ketac-Silver e Delton). Cem crianças tiveram um de seus molares selados com o Ketac-Silver e o dente homólogo com o Delton. Nas avaliações de seis e doze meses, a porcentagem de perda total dos selantes foi significantemente maior nos dentes selados com selante ionomérico, em relação aos selados com material resinoso. Embora não tenha havido diferença estatisticamente significante na incidência de cárie entre os dois grupos, os autores reafirmam que o Ketac-Silver não pode ser considerado uma alternativa para o selante à base de Bis-GMA. Sugeriram também que o baixo índice de retenção do selante de CIV pode ser atribuído à baixa resistência a esforços e não à baixa resistência a abrasão do material.

ARROW; RIODAN ${ }^{5}$ avaliaram o efeito preventivo e a retenção do cimento ionomérico Ketac-Fil, utilizado como selante, comparandoo com o selante resinoso Delton. Os selantes foram aplicados aos pares de primeiros molares permanentes em 415 crianças de sete anos de idade. Após um período de 3,5 anos, ambos os materiais apresentaram baixa retenção, 20,3\% e 27,9\% para o Ketac-Fil e o Delton, respectivamente. Essa diferença foi estatisticamente significativa. A baixa retenção do CIV era esperada devido a relatos 
de outros trabalhos, no entanto os selantes resinosos geralmente apresentam boa retenção, apresentando comportamento contrário nesse estudo. O motivo para tal não foi esclarecido, sendo a falta de controle da contaminação por saliva e o difícil manejo do paciente possíveis fatores responsáveis. Somente $4,5 \%$ dos dentes desenvolveram cárie durante o período estudado, sendo seis dentes selados com CIV e 31 com selante resinoso. Com relação ao KetacFil, a efetividade, correspondente à diferença entre o número de pares de dentes nos quais o grupo controle desenvolveu cárie pelo número onde o dente do grupo teste desenvolveu cárie, expressa como uma proporção de pares de dentes do grupo controle cariados, foi de $80,6 \%$ e a proporção de lesões cariosas prevenidas em cem tratamentos realizados através do uso desse material foi de $6,1 \%$ comparadas ao grupo controle. Esse estudo sugere que a completa retenção do selante ionomérico na fissura não é necessária para prevenir a cárie, principalmente em dentes recém erupcionados, com difícil controle da umidade.

Resultados contrários foram encontrados por RAADAL; UTKILEN; NILSEN ${ }^{83}$, em 1996, ao comparar o cimento de vidro fotopolimerizável modificado por resina (Vitrebond) com um selante resinoso (Concise White Sealant) durante um período de três anos, aplicados em 73 pares de primeiros e segundos molares 
permanentes recém-irrompidos. Concluíram que os selantes resinosos eram superiores aos selantes ionoméricos modificados por resina com relação à prevenção de cáries oclusais, e à retenção superior da resina provavelmente seria um fator importante para que isso ocorresse.

Os cimentos de ionômero de vidro usados para selamento de fossas e fissura podem ser os mesmos usados para forramento, base de restaurações, ou simplesmente os indicados para restauração, desde que manipulados numa consistência mais fluida do que quando se usa conforme o indicado pelo fabricante ${ }^{70}$.

JOHNSON et al. ${ }^{48}$ conscientes de que a proporção pó/líquido exerce importante papel nas propriedades físicas de um material, examinaram o efeito de várias proporções de um ionômero modificado por resina em relação a penetração de um corante na interface dente/material, quando utilizado como selante de fossas e fissuras. Para os cimentos ionoméricos, quanto maior a quantidade de pó, maior a resistência à abrasão, à compressão e menor é a solubilidade, no entanto maior é a viscosidade, que pode afetar negativamente a habilidade do material em escoar para dentro da fissura, reduzindo a capacidade de selamento. Foram utilizados dentes extraídos que receberam o selamento com o selante resinoso (grupo controle) e com diferentes proporções de ionômero modificado, 
$2,0: 1,0 ; 1,8: 1,0$ e 1,4:1,0 (grupos experimentais). Houve uma enorme diferença de penetração de corante entre os grupos controle e experimental. O selante resinoso demonstrou menos de $1 \%$ de penetração de corante. Já os grupos selados com o ionômero modificado demonstraram $67 \%$ à $79 \%$ de penetração na interface dente/selante. Era esperado que a proporção mais viscosa (2:1) do material penetrasse menos nas fissuras oclusais e proporcionasse um selamento menos efetivo. Entretanto, foi a proporção intermediária $(1,8: 1)$ que demonstrou a maior penetração de corante, indicando a necessidade de mais estudos sobre as propriedades físicas das diferentes proporções dos materiais ionoméricos. Apesar da liberação de flúor, e conseqüente efeito anticariogênico, os autores consideram prudente o uso de um sistema de selante que exiba mínima microinfiltração.

ARANDA; GARCIA-GODOY ${ }^{4}$ avaliaram a retenção e o desgaste de um selante de ionômero de vidro foto ativado experimental da GC por 12 meses, em estudo clínico através de inspeção visual, slides coloridos e réplicas dos dentes selados. Os resultados revelaram que visualmente apenas $20 \%$ dos selantes estavam clinicamente evidentes, no entanto, os modelos mostraram que apesar de ter ocorrido um considerável desgaste, o ionômero foi evidenciado no fundo das fissuras, atuando como um tampão, tendo como 
conseqüência o não desenvolvimento de cáries. O efeito cariostático mecânico do tampão é aumentado pela capacidade desse material de liberar flúor às estruturas adjacentes do dente e para o meio bucal ${ }^{4}$. Sendo o período eruptivo o mais crítico ao aparecimento de lesões ${ }^{67}$, em crianças com alto risco com molares parcialmente irrompidos, o uso do cimento de ionômero deve ser encorajado ao invés da tradicional conduta de esperar até que o dente esteja totalmente irrompido ${ }^{4}$. A diferença nos níveis de retenção entre a réplica e a avaliação clínica constatadas neste estudo reflete a dificuldade em julgar clinicamente a retenção de um selante degradado ou desgastado, confirmando os estudos de MEJARE; MJOR ${ }^{63}$.

Quando se analisa o uso do CIV como selante, um fato a se considerar é sua baixa resistência ao desgaste, que contribui a uma rápida degradação do mesmo, tornando-o fino e mais susceptível a fraturas, o que poderia leva-lo para fora da superfície do esmalte ${ }^{4}$.

\section{2- Propriedade de desgaste}

MILLER $^{64}$, em 1907, foi um dos pioneiros a demonstrar preocupação com relação à ação abrasiva dos dentifrícios sobre as restaurações e estruturas dentárias, em três fascículos, um artigo com 62 páginas, intitulado: “Experimentos e observações sobre o desgaste 
dos tecidos dentários designado como erosão, abrasão química, denudação, etc.". O autor apresentou casos clínicos e fez ensaios em laboratório para avaliar a ação de diversos agentes físicos, químicos e biológicos sobre as estruturas dentais e suas restaurações. Em um dos experimentos, dentes extraídos, portadores ou não de restaurações, foram submetidos à escovação com pedra-pomes, a $10 \%$, por 90 minutos, e foi possível observar o rápido desgaste da dentina, enquanto sobre o amálgama apareceram sulcos superficiais; e o ouro, apesar de menos duro que a dentina, sofreu menor desgaste, perdendo apenas para a resistência do esmalte. Entre outras observações, o autor pôde concluir que os ácidos em geral, especialmente na concentração em que ocorrem na boca, não são capazes de produzir desgaste, sendo o maior responsável pela abrasão dos tecidos duros o processo mecânico da escovação dentária.

GRABENSTETTER et $\mathrm{al}^{34}$. em 1958, avaliaram a abrasão provocada em dentes humanos por abrasivos de dentifrícios, utilizando um teste com dentes submetidos a uma radiação de nêutrons. Os dentes foram, então, adaptados a uma máquina de escovação, em que a velocidade e a pressão da escova podiam ser controladas. A seguir, $2 \mathrm{ml}$ da solução com abrasivo foram recolhidos, secos a $105^{\circ} \mathrm{C}$ e pesados. A radioatividade foi então medida e 
relacionada com a quantidade de estrutura dental abrasionada. Também foi possível calcular o poder de abrasão de cada um dos materiais. Os autores concluíram que este método é mais preciso e mais rápido do que aqueles dependentes da medida da profundidade dos sulcos provocados pelos abrasivos, pois seu coeficiente de variação foi mais baixo e houve necessidade de menos dentes e menor tempo de escovação. Os resultados obtidos em termos de quantidade de estrutura dentária perdida mostraram que a taxa de esmalte abrasionado correspondeu a apenas 1 a $5 \%$ da quantidade de dentina perdida.

Os dentifrícios sob condições de escovação normais, idealmente deveriam prover o máximo de limpeza e polimento e o mínimo de abrasão. Em 1968, STOOKEY; MUHLER ${ }^{99}$ realizaram vários estudos in vitro para avaliar as propriedades abrasivas de 43 dentifrícios sobre as estruturas duras do dente. Inicialmente, os dentes recém-extraídos foram irradiados e submetidos ao teste de abrasão numa máquina de escovação sob pressão de $150 \mathrm{~g}$, com 1.000 ciclos para a dentina, e 3.000 para o esmalte, utilizando a técnica de Grabenstetter. Já, para a técnica de medição da abrasão pela perda de peso, foram necessários 50.000 ciclos. Muitas variáveis, como número de ciclos de escovação, pressão de escovação, tipo de abrasivo e lote, foram introduzidas nos experimentos. Os resultados mostraram que os 
valores de abrasão de esmalte aumentavam linearmente, até o emprego de 4.000 ciclos, e à medida que aumentava a pressão de escovação, aumentava também o desgaste tanto da dentina quanto do esmalte. Além disso, foi possível observar uma correlação positiva entre a técnica de perda de peso, quando comparada com a técnica de traçadores radioativos. Houve diferença significante dos valores da abrasão entre os abrasivos, diferença entre diferentes marcas de dentifrícios que continham o mesmo tipo de abrasivo e diferença de abrasividade nos lotes de um mesmo dentifrício. Foram avaliadas também, a capacidade de polimento, que diferiu muito entre os dentifrícios, e a capacidade de limpeza, sendo satisfatória para todos eles. Os resultados encontrados confirmaram a abrasividade decrescente das fórmulas do tipo pó seguida pela do tipo pasta e por fim a do tipo líquida ou gel.

HEATH; WILSON ${ }^{41}$, em 1976, desenvolveram um método laboratorial para medir a abrasão dos materiais restauradores, pela associação escova de dentes/dentifrício. Nos testes, foi utilizada uma máquina de abrasão que consistia de um motor que movimentava um jogo de engrenagens e hastes, em cujas extremidades eram fixadas as cabeças das escovas de dentes macias. O dentifrício de carbonato de cálcio era diluído para simular a saliva e reduzir a sedimentação do abrasivo, e colocado em um recipiente, onde também eram fixados os 
espécimes a serem analisados (materiais restauradores: ouro, amálgama, silicatos e resinas). Em uma primeira fase, todos os espécimes foram submetidos à abrasão a $37^{\circ} \mathrm{C}$, usando $5 \mathrm{~N}$ de pressão, em um movimento de $45 \mathrm{~mm}$ da escova e velocidade de 4 a 5 movimentos por segundo, até totalizar 20.000 ciclos. O teste propriamente dito, foi conduzido 24 horas depois e consistiu de 20.000 movimentos; o equivalente a dez meses de desgaste na boca, usando um novo jogo de três escovas, que eram movidas de recipiente para recipiente, para que cada espécime recebesse um número igual de movimentos de cada escova. A análise foi efetuada através de um perfilômetro Talysurf, com o qual pôde se avaliar a quantidade de material removido dos corpos de prova. O trabalho também discutiu alguns fatores que poderiam influenciar os resultados como: idade das escovas, comprimento do movimento das escovas, pressão aplicada pela escova e a temperatura.

HEFFERREN ${ }^{42}$, em 1976, descreveu o método específico de medir a abrasividade, in vitro, dos dentifrícios de acordo com o Comitê de Abrasão Laboratorial do Programa de Dentifrícios da Associação Dentária Americana (ADA). Foram levantados aspectos com relação aos cuidados necessários na seleção e preparo dos dentes, irradiação e montagem das raízes, bem como a descrição do funcionamento da máquina de escovação. Escovas, material abrasivo, preparo do 
diluente, preparo da solução abrasiva, remoção das amostras do contador radioativo, secagem das amostras, contagem radioativa, cálculo da abrasividade e fatores de correlação foram itens abordados e estabelecidos pelo referido Comitê. Com relação ao cálculo da abrasividade, ficou claro que o método baseado na perda de peso não é recomendado para os tecidos dentários, uma vez que leva a resultados falhos, já que a variação do conteúdo de água deles afeta seriamente a medida da perda de peso pela abrasão, no entanto é um método satisfatório quando utilizado para materiais restauradores. A utilização de perfilômetro foi descartada porque os aparelhos são delicados e caros, sendo que o melhor método seria a contagem radioativa do material desgastado. Também ficou estabelecido que o teste de laboratório é um passo necessário para entender a situação clínica, considerando a enormidade de variáveis que ocorrem in vivo.

A avaliação da abrasão provocada por 23 marcas comerciais de dentifrícios sobre placas de plex-glass, submetidas à escovação mecânica com escovas macias (Multi-Cerda) foi realizada por PANZERI et al. ${ }^{81}$, em 1979. O tempo de escovação na máquina tipo Pepsodent foi de 60 minutos para todos os corpos de prova, que mediam $88 \times 27 \mathrm{~mm}$. Os corpos de prova foram pesados antes e após o ensaio de escovação, e a perda de peso variou de $0,0233 \mathrm{~g}$ para aqueles escovados com Ultra Brite até $0,0023 \mathrm{~g}$ para aqueles 
escovados com água. Também foram feitos registros fotográficos, com 20 vezes de aumento, sendo que os valores quantitativos de perda de peso foram comparáveis aos visualizados nas fotografias. Os autores sugeriram que, do ponto da vista de higienização dos dentes, o ideal seria o uso de dentifrícios abrasivos intercalados com aqueles não abrasivos, já que as exigências que são feitas aos dentifrícios é que eles devem limpar e polir os dentes, melhorar o estado gengival, eliminar os depósitos de manchas e tártaro, reduzir a placa bacteriana e prevenir a cárie e as periodontopatias sem riscar ou desgastar exageradamente o esmalte e a dentina, irritar a mucosa gengival ou alterar os materiais restauradores.

Em 1980, foi proposto um teste laboratorial de abrasão para resinas compostas por EHRNFORD et al. ${ }^{21}$, que afirmavam serem os testes clínicos de longa duração os mais fiéis para este tipo de estudo, no entanto há desvantagens de tempo requerido, dificuldades na quantificação do desgaste e inabilidade de interpretação dos resultados com relação aos mecanismos responsáveis por gerar o desgaste. Os autores relataram a combinação do teste a dois corpos com uma mistura aquosa de pérolas de vidro e partículas abrasivas, para o desgaste não ocorrer apenas por abrasão, mas também por fadiga, corrosão e desgaste adesivo. Os corpos de prova foram confeccionados em uma matriz de $5 \times 10 \mathrm{~mm}$ com uma superfície 
curva, armazenados em água a $37^{\circ} \mathrm{C}$ por uma semana e submetidos ao teste, em que foram colocados em um disco circular presos em quatro braços. O motor programado para girar $2,5 \mathrm{~mm}$ em cada direção, com uma pausa de 15 segundos por uma hora, fazia o movimento do disco a uma velocidade de 1,4 m/Seg. A quantidade de abrasão foi expressa pela diferença entre a altura do corpo de prova antes e após o ciclo, e a verificação da superfície abrasionada foi feita utilizando-se a microscopia eletrônica de varredura. Concluíram que o teste é importante porque apresentou a mesma ordem de desgaste observada clinicamente, porém, deve ser usado com ressalvas, apenas entre grupo de materiais onde a diferença na composição não possa afetar significativamente o mecanismo de desgaste.

McCABE; SMITH ${ }^{58}$, em 1981, relataram que a existência de grandes forças de desgaste e o uso de materiais com inadequada resistência à abrasão pode resultar em substancial alteração no contorno da restauração ou do selamento. Devido ao estabelecimento empírico da relação de dois mecanismos de desgaste (a dois e três corpos) com a abrasão da cavidade oral, propuseram um novo método para medir o desgaste "in vitro" de materiais restauradores que incorporasse abrasão e fadiga, consistindo em vibrar corpos de prova cilíndricos dentro de um recipiente contendo papel abrasivo de carbide e silica. Os corpos de prova foram armazenados em água por 
um período de uma semana antes do teste. Cada recipiente sofria vibração por 20 minutos, e depois eram mudados de posição. Ao término de 80 minutos, os corpos de prova eram pesados e os abrasivos trocados, os testes foram repetidos três vezes, totalizando um tempo de 320 minutos. O grau de desgaste foi medido pela perda de peso e depois convertido em perda de volume. Os resultados encontrados foram semelhantes aos de pesquisas clínicas, pois possivelmente o desgaste clínico do material ocorra pela combinação de desgaste por abrasão e fadiga, sendo que o método seria válido para prever o valor de desgaste de materiais.

AKER $^{1}$, em 1982, publicou um trabalho de comparação da resistência a abrasão por escovação de resinas compostas e as características das superfícies abrasionadas. Apesar dos materiais testados serem diferentes, a metodologia é semelhante à do presente estudo. A máquina de escovação possuía um motor elétrico, responsável pela movimentação de quatro hastes em cujas extremidades se posicionavam as cabeças das escovas dentárias. Reservatórios continham uma base de metal resistente à abrasão onde se localizavam os corpos de prova e a mistura abrasiva (45g de Colgate MFP e $45 \mathrm{ml}$ de água destilada). A capacidade do motor era de 16.000 ciclos de escovação por uma hora, o que corresponde a 22 ciclos de escovação, duas vezes ao dia, por um ano. A resistência à 
abrasão foi medida pela determinação do volume de material perdido durante $o$ teste. Os materiais testados foram mantidos imersos em água a $37^{\circ} \mathrm{C}$ até que atingissem um estado máximo de absorção. Os espécimes eram pesados, tirando o excesso de água, a cada 24 horas, e o peso era considerado constante quando, após cinco pesagens consecutivas, variasse no máximo $0,1 \mathrm{mg}$. No estudo, os corpos foram escovados por 15 horas, trocando as escovas e a mistura em um intervalo de cinco horas. Foram utilizadas micrografias eletrônicas das superfícies abrasionadas para ilustrar as características da superfície de cada material, e observou-se a ocorrência de estrias e ondulações na maioria delas, causada pela aplicação repetitiva e unidirecional das escovas.

HARRINGTON et al. ${ }^{39}$, em 1982, apresentaram um método para medir a ação abrasiva da escovação sobre os materiais restauradores. A máquina de escovação consistia de um cabo central horizontal de secção hexagonal que, ligado a um motor, rodava a uma velocidade de 120rpm por 25 segundos, com uma parada de cinco segundos, para depois fazer o mesmo no sentido contrário. A cada seis segundos o cabo movimentava-se no seu longo eixo por $2 \mathrm{~mm}$. A solução de $100 \mathrm{ml}$ de dentifrício foi mantida a $37^{\circ} \mathrm{C}$ numa cuba situada sob o cabo central, no qual foram afixadas 18 escovas Oral B 60, de tal forma que uma projeção de $2 \mathrm{~mm}$ dos tufos das mesmas 
esfregassem os corpos de prova ciclicamente e que cada espécime sofresse escovação por três escovas. Foram utilizadas 17 marcas comerciais de materiais restauradores (amálgama, iônomero de vidro, silicato, selante, compósito convencional, de micropartículas e resina sem carga) para confeccionar seis corpos de prova de cada um, com $10 \mathrm{~mm}$ de diâmetro e $1 \mathrm{~mm}$ de espessura, em matrizes de Teflon, de tal forma que quando posicionados na máquina de escovação estabelecessem um posicionamento de $0,5 \mathrm{~mm}$ acima da base. Os materiais foram manipulados de acordo com as instruções do fabricante, sendo que o silicato, os ionômeros de vidro e as resinas de auto e fotopolimerização tomaram presa sob uma tira-matriz de acetato de celulose. A seguir, o silicato e os ionômeros de vidro foram mantidos a $37^{\circ} \mathrm{C}$ e $95 \%$ de umidade relativa do ar por 24 horas, para depois serem submersos em água destilada a $37^{\circ} \mathrm{C}$, juntamente com os outros materiais. Após sete dias, os corpos de prova foram secos com um tecido, pesados e tiveram a sua rugosidade inicial medida com o Talysurf 4, bem como a espessura, usando um micrômetro. Então, os corpos de prova foram submetidos a 60.000 ciclos de escovação, quando tiveram novamente sua rugosidade, peso e espessura medidos. A perda de densidade foi calculada dividindo-se a perda de peso pelo peso original e multiplicando-se esse resultado pela espessura original. Os resultados mostraram que as resinas sem 
carga mantiveram sua lisura, o único material que melhorou a lisura foi o amálgama, enquanto todos outros, partindo de uma boa lisura, tornaram-se muito mais rugosos após a escovação. Os materiais que menos perderam em densidade foram os compósitos convencionais juntamente com o silicato e o amálgama, seguidos pelos ionômeros de vidro, selantes resinosos, resinas sem carga e compósitos de micropartículas. Não foi possível definir uma correlação entre a rugosidade final e a perda de material.

De BOER et al. ${ }^{18}$, em 1985, avaliaram a influência do tamanho da partícula do abrasivo presente no dentifrício e da dureza da escova dental, na abrasão dentinária, in vitro. Foi utilizada uma máquina de escovação com ensaios de 1.000, 2.000, 5.000 e 10.000 escovações, com $200 \mathrm{~g}$ de carga, e os dentifrícios com dois tamanhos de partículas: 7 e 15um de diâmetro para $\circ \mathrm{CaCO}_{3}$ e, 8 e 13um para o $\mathrm{Al}(\mathrm{OH})_{3}$. A abrasão foi medida com um perfilômetro superficial (Perth-O-Meter) e expressa em profundidade média. Os dados do perfilômetro forneceram informações sobre a formação de sulcos e a quantidade média de material removido, através de cálculos matemáticos. Os resultados mostraram que a abrasão foi diretamente proporcional ao número de escovações, que as escovas sem dentifrício não provocaram abrasão e com dentifrício, a dura, foi 1,4 vezes mais abrasiva que a macia, e houve diferença significativa entre a taxa de 
abrasão dos quatro sistemas abrasivos utilizados, sendo a maior abrasão provocada pelos dentifrícios com as maiores partículas abrasivas.

A determinação da influência química no desgaste de materiais através de simuladores de líquidos e comidas, foi estudada por McKINNEY; WU ${ }^{60}$, em 1985. Os materiais testados foram resinas compostas, submetidas a um condicionamento em soluções aquosas de etanol por uma semana e posteriormente ao teste de abrasão a dois corpos (pino e disco). Os resultados mostraram que todas as resinas compostas testadas revelaram danos resultantes do pré condicionamento por simuladores de alimentos químicos. O maior efeito de todos foi obtido com etanol a $75 \%$, significando que qualquer componente oral ou ingrediente de alimento com estas características produzirá danos nos materiais restauradores. O mecanismo de ação é atribuído ao amolecimento da matriz, e conseqüente remoção parcial de sua superfície, e essa degradação resultou em redução da dureza e aumento do desgaste.

MURRAY et al. ${ }^{66}$, em 1986, compararam, in situ e in vitro, a ação abrasiva de quatro dentifrícios sobre dentes artificiais para dentaduras, esmalte, dentina e Perspex. Para o ensaio laboratorial foi utilizada uma máquina de escovação, onde eram acopladas escovas Oral B 40, cuja velocidade era de 150 ciclos por minuto, com $200 \mathrm{~g}$ de 
carga. Os corpos de prova de Perspex, dentina e esmalte foram submetidos a 5.000, 5.000 e 50.000 ciclos de escovação, respectivamente. $\mathrm{Na}$ superfície dos mesmos foram produzidas penetrações de tamanhos diferentes com o diamante, para medida de dureza Vickers, e, a cada intervalo de cem ciclos, as penetrações eram observadas e a rugosidade medida com 0 perfilômetro Surfometer. À medida que as penetrações iam desaparecendo, os corpos de prova recebiam um escore de 0 a 4 . Para o experimento in situ foram utilizados 70 pacientes portadores de dentaduras novas, sendo que a face vestibular da cúspide mesial do primeiro molar inferior direito foi polida de tal forma a conseguir uma superfície totalmente plana. Penetrações idênticas às usadas no ensaio in vitro foram produzidas também nos dentes de acrílico. Os pacientes foram instruídos para escovar as dentaduras diariamente duas vezes por dois minutos com um dos dentifrícios e a escova Oral B 35. As medidas foram feitas após um e seis meses. Os resultados mostraram que o menor desgaste foi provocado pelo dentifrício cujo abrasivo eram pérolas de resina acrílica, inclusive causou uma abrasão tão pequena no esmalte e na dentina, que não pode ser detectada pelo perfilômetro. Não houve diferença de desgaste estatisticamente significante provocada pelos três outros dentifrícios nos corpos de Perplex, no entanto na dentina e no esmalte o dentifrício de fosfato de 
cálcio foi menos abrasivo que os dois que possuíam carbonato de cálcio em sua composição, ressaltando que os valores de desgaste no esmalte foram bem menores em relação aos na dentina. Observou-se que quanto maior foi a abrasividade, maior a rugosidade provocada pelo dentifrício nos dentes artificiais e na dentina, não tendo o esmalte sofrido alterações significativas na sua rugosidade. Tanto in vitro como in situ ocorreu a mesma ordem de abrasividade para os quatro dentifrícios.

LEINFELDER; WILDER; TEIXEIRA ${ }^{52}$, em 1986, utilizaram dois diferentes métodos para avaliar o desgaste clínico de resinas compostas utilizadas para restaurar dentes posteriores. Compararam a avaliação clínica direta, quantificadora da perda da forma anatômica, com um método de avaliação através de modelos de gesso dos dentes restaurados comparados à modelos de gesso padronizados. Os autores concluíram que a quantidade de desgaste depende do método, pois a avaliação clínica direta sugeriu que houve aumento de desgaste e a indireta, através de modelos, sugeriu uma diminuição de desgaste com o tempo.

Em 1987, FINGER; THIEMANN ${ }^{22}$ relatando a necessidade de um estudo laboratorial que simulasse o desgaste clínico oclusal de materiais restauradores e seladores, propuseram um novo método. A resistência oclusal de 24 marcas comerciais de resinas restauradoras 
e um amálgama foi estudada através de uma simulação por carga. Os corpos de prova foram confeccionados, mantidos imersos em água a $37^{\circ} \mathrm{C}$ por duas semanas e posteriormente submetidos ao teste (a três corpos) numa máquina contendo duas rodas com movimentos circulares antagônicos, sendo que uma abrigava os corpos de prova e a outra funcionava como uma cúspide antagonista, fazendo pressão de $10 \mathrm{~N}$ numa velocidade de $1.000 \mathrm{~m} / \mathrm{h}$. O abrasivo usado foi uma mistura aquosa a $25 \%$ de sementes de papoula. A perda de material foi determinada pela área incluída entre o registro traçado por um perfilômetro antes e depois do período de teste. Os resultados apresentaram concordância linear com as experiências clínicas. Através do estudo da superfície dos materiais por microscopia eletrônica de varredura, verificou-se morfologia similar entre os materiais do estudo "in vitro" e "in vivo", indicando que o método descrito poderia simular o mecanismo de desgaste oclusal.

O exato mecanismo de desgaste na área de contato oclusal de restaurações dentárias não é totalmente compreendido. Pode ser considerado uma combinação de abrasão, adesão, desintegração química e fadiga da superfície. Com o intuito de simular esses quatro tipos de desgaste em combinação, KREJEI; LUTZ; ZELDER ${ }^{51}$, em 1992, realizaram um estudo e avaliaram o efeito da dimensão da área de contato no desgaste de espécimes de materiais e no desgaste das 
cúspides de esmalte antagonistas. Trinta e seis espécimes cilíndricas de resina composta foram posicionadas em cavidades de metal $(8 \mathrm{~mm}$ X $2 \mathrm{~mm}$ ) e divididas em cinco grupos, cada qual submetido a uma determinada medida de área de contato oclusal. $O$ experimento consistiu das seguintes etapas: armazenamento dos espécimes em solução aquosa de etanol a $75 \%$ por 24 horas; abrasão por teste de escovação com força de $2 \mathrm{~N}$ por 30 minutos, utilizando-se uma mistura de duas partes de dentifrício para uma parte de água; 300 ciclos de termociclagem em água $\left(5^{\circ}\right.$ a $\left.55^{\circ} \mathrm{C}\right)$ simultaneamente a 120.000 mordidas oclusais, através de molares superiores humanos extraídos, com freqüência de $1,7 \mathrm{~Hz}$ e força máxima de $53 \mathrm{~N}$. O mais severo desgaste da resina composta foi encontrado no espécime cujo antagonista possuía esmalte com menor área de contato, logo a extensão e o mecanismo do desgaste foram relacionados com a pressão da mordida, que era determinada pela dimensão da área de contato.

MOORE; WINKLER; EWOLDSEN ${ }^{65}$, em 1995, realizaram testes laboratoriais com ionomêros de vidro modificados por resina utilizados como selantes de fossas e fissuras, por estes apresentarem as vantagens de menor sensibilidade à hidratação e desidratação, e controle da polimerização pelo operador, em relação aos ionômeros convencionais. Os autores afirmaram que os CIV Tipo II (restauração) 
poderiam competir favoravelmente com os selantes resinosos devido às suas propriedades adicionais de liberação de flúor e inibição de microorganismos cariogênicos. Compararam a penetração, a capacidade de selamento e a resistência à abrasão de ionômeros de vidro modificados por resina Tipo II (Fuji II e Vitremer) em relação a um selante resinoso (Concise White). No teste de abrasão foram confeccionados 12 corpos de prova ( $20 \mathrm{~mm} \times 2 \mathrm{~mm}$ ) para cada grupo, armazenados em umidade relativa de $100 \%$ por sete dias, posteriormente pesados e submetidos ao teste através da utilização de uma máquina de escovação (The Pepsodent Co., Chicago) por duas horas, com uma mistura abrasiva de $15 \mathrm{~g}$ de carbonato de cálcio em 15ml de água destilada. Os resultados mostraram que a abrasão , quantificada pela perda de volume, do selante resinoso foi menor seguido pelo Fuji II e Vitremer. Justificaram afirmando que a abrasão da matriz do CIV e a retirada de partículas de vidro acelerariam o desgaste e com relação à penetração, os ionômeros penetraram no ápice das fissuras com maior freqüência, o que seria favorável, pois a completa penetração em todas as fossas e fissuras reduziria o risco dessas a reexposição após a perda parcial dos selantes; não houve diferença entre os materiais, quanto à capacidade de isolar as fissuras (infiltração marginal). Concluíram que o estudo suportaria o uso 
clínico, como selantes de fossas e fissuras, de cimentos de ionômero de vidro restauradores modificados por resina.

\section{3- Propriedade de Rugosidade}

A textura ou rugosidade superficial caracteriza-se pelas microirregularidades geométricas deixadas na superfície do material decorrentes do processo de fabricação ou decorrentes da interação com processos de desgaste. A rugosidade de uma superfície é basicamente quantificada através de parâmetros relacionados à altura (amplitude) e largura (ou espaçamento) das irregularidades. CARPENETTI et al ${ }^{110}$. do Departamento de Engenharia Mecânica da USP publicaram, em 1996, um trabalho sobre os conceitos e princípios da rugosidade superficial. Os autores afirmaram que a rugosidade influi no comportamento das superfícies em vários aspectos como atrito, ajuste oclusal, desgaste, corrosão, aparência, resistência à fadiga, propriedades óticas, escoamento de fluídos e adesão. Segundo a NBR $6405^{6}$, existem definições importantes referentes à rugosidade, como Superfície Real (superfície que limita um corpo e o separa do meio ambiente); Superfície Geométrica (onde não existem erros de forma e de acabamento); Superfície Efetiva (obtida através de instrumentos analisadores de superfície); Perfil 
Real (intersecção da superfície real com um plano perpendicular à superfície geométrica); Perfil Geométrico (intersecção da superfície geométrica com um plano perpendicular a ela); Perfil Efetivo (intersecção da superfície efetiva com um plano perpendicular à superfície geométrica); Comprimento da amostragem (L- comprimento medido na direção geral do perfil, suficiente para a avaliação dos parâmetros de rugosidade); Linha Média (LM- é a linha paralela à direção geral do perfil, no comprimento da amostragem, colocada de tal modo que a soma das áreas superiores, compreendidas entre o perfil efetivo, seja igual à soma das áreas inferiores); Desvio Médio Aritmético $\left(\mathrm{R}_{\mathrm{a}-}\right.$ média dos valores absolutos das ordenadas do perfil efetivo (y) em relação à linha média, num comprimento de amostragem). Segundo o autor, o parâmetro $R_{a}$ é utilizado para avaliar a rugosidade superficial dos materiais, principalmente no Brasil, Estados Unidos e Inglaterra.

No estudo da rugosidade de superfícies deve se fazer distinção entre rugosidade e curvatura (forma), através da filtração onde há retirada de oscilações de longa distância. LEITÃO; HEGDAHL ${ }^{53}$, em 1981, apresentaram um estudo onde definiram alguns parâmetros de rugosidade, freqüentemente utilizados em pesquisas odontológicas, e discutiram algumas de suas propriedades. Os autores usaram 25 corpos de prova de amálgama polidos, de $5 \mathrm{~mm}$, para explicar e 
demonstrar a sua teoria. Em geral, uma superfície é considerada rugosa quando caracterizada por protrusões e recessos de grande amplitude em pequenas distâncias. A rugosidade pode ser determinada através de dados fornecidos por um apalpador que percorre uma superfície, definindo picos e vales. $O$ valor chamado $R_{a}$ é calculado dividindo-se, de acordo com uma fórmula matemática, a área de picos e vales pela distância, em linha reta, percorrida pelo apalpador. $O$ valor $R_{a}$ freqüentemente também é designado CLA. Existem também os parâmetros $R_{s}$, designado $R M S$, $R_{t}$, entre outros definidos na literatura. $O$ valor $R_{s}$ é calculado de maneira semelhante ao $R_{a}$, no entanto a área de picos e vales é elavada ao quadrado e depois extrai-se a raiz quadrada, de tal modo que se obtenha valores em módulo. O rugosímetro utilizado foi o Perthometer (Perthen Mahr). O valor do cut-off é a distância efetiva que o apalpador deve percorrer para calcular a rugosidade. Os resultados mostraram que um valor maior de cut-off implicou um aumento no valor da rugosidade, e quando não há filtração o valor correspondente do cut-off é infinito. $O$ valor de $R_{a}$ aumentou $32 \%$ quando o cut-off passou de 0,25 para $0,8 \mathrm{~mm}$. Segundo os autores, o valor de $R_{t}$ é muito limitado para informar sobre toda superfície, pois fornece apenas a distância máxima entre picos e vales, enquanto o valor de $R_{s}$ está bastante indicado em superfícies com muitas bolhas. O parâmetro de 
rugosidade deve ser bem escolhido e o valor de cut-off, selecionado e definido, para não confundir rugosidade com curvatura e para que as informações obtidas sejam as mais corretas possíveis.

\section{4- Relação entre Rugosidade Superficial e Placa Dentária}

NORMAN et al. ${ }^{75}$, em 1972, investigaram a natureza da placa bacteriana formada nas margens de restaurações de amálgama, ouro coesivo, ouro fundido, resina e cimento de silicato. Na primeira etapa, foi coletada a placa de 120 restaurações realizadas há, pelo menos, dois anos. Os pacientes foram instruídos a não escovarem os dentes por três dias, não usar goma de mascar e fazer bochecho com glicose, quatro horas antes da coleta das placas acumuladas, na margem gengival, numa região dentária adjacente à restauração, no terço médio da restauração e em outra face do dente. A placa de cada região foi colocada em solução e submetida à análise de carboidrato, nitrogênio, cálcio e fósforo. A segunda etapa do estudo consistiu em realizar dez restaurações, dos materiais em questão, em novos pacientes. Nesses, as coletas foram realizadas imediatamente após a restauração e repetidas após três meses, seis meses e um ano. Os resultados mostraram que a composição da placa formada nas margens dos diferentes materiais restauradores não diferiu daquela 
que se formou nas superfícies dentárias adjacentes às restaurações. A placa que se forma na superfície adjacente pareceu ser uma extensão da placa da margem da restauração, pois a composição de uma varia quando varia a composição da outra. Durante o primeiro ano a composição da placa é influenciada pelo material restaurador, os fatores responsáveis por este fenômeno são desconhecidos, neste período talvez haja mudanças no padrão de infiltração marginal ou sorpção de substâncias nas porosidades e irregularidades destas restaurações. Também pode ocorrer corrosão e é provável que o potencial elétrico de uma restauração recente seja diferente daquele de uma restauração antiga, que já atingiu um relativo equilíbrio. Houve pouca diferença na composição da placa sobre as margens dos diferentes materiais restauradores, exceto para o silicato, que apresentou um alto conteúdo de carboidrato em relação ao nitrogênio, mesmo em restaurações antigas, e um menor nível de nitrogênio em relação ao cálcio. Esses dados sugeriram que o carboidrato foi menos metabolizado pela placa, ou que havia menos bactérias presentes na placa, sendo que o flúor liberado atuaria como um inibidor enzimático, interferindo no metabolismo dos carboidratos. Com relação aos níveis de cálcio em relação ao fosfato na placa não houve diferença entre os materiais. Os autores apresentaram a necessidade de pesquisas 
para determinar se o flúor é o componente do silicato responsável pela alteração na composição da placa.

SMALES ${ }^{97}$, em 1981, avaliou o crescimento e a retenção da placa bacteriana sobre materiais restauradores colocados em molares e pré-molares de dez dentaduras artificiais. Foram utilizadas três ligas para amálgama, duas resinas compostas e um cimento de ionômero de vidro (ASPA) para restaurar seis cavidades classe $V(3 \times 2 \mathrm{~mm})$ em cada dentadura. O cimento de ionômero de vidro foi protegido com verniz, e após uma semana, todas as restaurações sofreram acabamento e polimento com discos de lixa e polimento com taça de borracha. Os pacientes receberam instruções quanto ao tipo de dieta, e para não limpar ou manipular as superfícies restauradas dois dias antes da avaliação da placa, que ocorreu duas a três semanas após, quando a placa foi totalmente removida. As restaurações foram fotografadas e sua rugosidade analisada com um Rugotest, um perfilômetro (Serftest-III) e microscopia eletrônica de varredura. Os resultados mostraram que houve associação entre a rugosidade superficial das restaurações e a quantidade de placa presente, sendo que o ASPA $(2,72 \mu \mathrm{m})$ apresentou-se como o material mais rugoso e aquele que reteve maior quantidade de placa. Não foi encontrada relação entre a localização do dente, a quantidade de açúcar da dieta e a quantidade de placa presente sobre as restaurações. 
SKJORLAND et al. ${ }^{96}$, em 1982, realizaram um trabalho para verificar se a topografia superficial das restaurações, especialmente as porosidades, poderiam justificar as diferenças em relação ao acúmulo inicial de bactérias sobre 15 marcas comerciais de compósitos e silicatos. Os corpos de prova com 5X10mm foram confeccionados de acordo com as especificações do fabricante. Após o polimento, a imagem dos corpos de prova foi projetada com aumento de 110 vezes, para determinar o número e a distribuição dos poros através do método de contagem de pontos. A rugosidade superficial também foi determinada com um rugosímetro (Perth-OMeter). Outros corpos de prova foram incubados verticalmente numa suspensão de Streptococcus sanguis a $37^{\circ} \mathrm{C}$. Sendo posteriormente fixados com etanol por 48 horas, secos e metalizados para serem observados sob microscopia eletrônica de varredura. Os resultados mostraram grande variação entre os materiais quanto ao número de poros, entretanto o teste de adesão bacteriana in vitro demonstrou que a topografia da superfície dos materiais, inclusive os poros, não exerce influência na aderência inicial de bactérias.

Geralmente o nível de Streptococcus mutans está associado ao desenvolvimento de cáries, e os materiais restauradores não só influenciam na adesão bacteriana como na quantidade desse microorganismo na placa. Em 1990, SVANBERG ${ }^{103}$ et al. 
compararam os níveis de streptococcus mutans em amostras de placa em restaurações classe II de amálgama (Dispersalloy), resina composta (P-10) e ionômero de vidro (Ketac Silver), usando meio de cultura de ágar MSB (ágar mitis salivares com sacarose e bacitracina). Três grupos de 17 crianças entre 8 e 15 anos, com um dos primeiros molares restaurados, fizeram parte da comparação interindividual. Outras sete crianças por apresentarem restaurações de ionômero de vidro e resina de mesma idade em molares e pré-molares contralaterais, fizeram parte da comparação intra-individual. As restaurações de ionômero foram injetadas com seringa, esculpidas e alisadas com um instrumento plástico, e protegidas com verniz à prova de água. Após a remoção do isolamento absoluto, o contato oclusal foi ajustado, acabado e novamente protegido com verniz. Para fazer a contagem de unidades formadora de colônias (CFU) foi coletada saliva, e placa com a ponta de uma agulha hipodérmica estéril das margens interproximais das faces vestibular e lingual das restaurações classe II. Houve correlação estatisticamente significante entre os resultados encontrados na saliva e na placa. A porcentagem de streptococcus mutans da contagem total de CFU na placa foi maior no compósito $(13,7)$ e amálgama $(4,3)$ do que no ionômero $(1,1)$ na comparação interindividual; e maior para o compósito $(4,2)$ do que para o ionômero de vidro $(0,4)$ na comparação intra-individual. Em 
ambos os casos, as diferenças entre as amostras sobre o ionômero e compósito ou amálgama foram estatisticamente significativas $(p<0,05)$. As restaurações tinham em média 24 meses de idade, e uma liberação contínua de flúor e prata das restaurações de ionômero de vidro pode ter contribuído para o baixo nível de microrganismos encontrado na placa sobre o cimento ionomérico em comparação com os outros materiais restauradores. Os resultados sugeriram que, por períodos prolongados de tempo, o potencial cariogênico da placa que existe sobre o ionômero é bem mais baixo do que da placa que existe sobre o compósito e o amálgama no sentido de induzir a formação de cárie secundária.

No mesmo ano, os autores ${ }^{102}$ publicaram um estudo onde se analisaram os níveis de streptococcus mutans na placa interproximal coletada sobre restaurações. Vinte adolescentes voluntários de 13 a 17 anos de idade com lesões de cárie iniciais em dentes permanentes posteriores foram selecionados para fazerem parte do estudo, onde um grupo foi tratado com restaurações conservadoras classe II de amálgama (Dispersalloy) e outro grupo com restaurações classe II tipo túnel de cimento de ionômero de vidro (Ketac Silver). As restaurações foram confeccionadas obedecendo às indicações clínicas e às orientações do fabricante. A saliva estimulada e a placa foram coletadas antes do tratamento restaurador e após três a cinco 
semanas sendo posteriormente incubadas em meio de cultura com ágar-sangue para contagem do número de unidades formadoras de colônia (CFU) e meio MSB para identificação do streptococcus. Os resultados mostraram que a porcentagem de streptococcus mutans viáveis das amostras recolhidas sobre as restaurações de ionômero de vidro $(3,1 \%)$ foi significativamente mais baixa do que a da placa que se formou sobre o amálgama (5,7\%). A liberação de íons de prata e de flúor podem ser os responsáveis pela redução da acidogenicidade da placa, não favorecendo o desenvolvimento do Streptococcus mutans. Estes dados sugeriram que a placa formada sobre o ionômero de vidro tem um potencial bem mais baixo no sentido de induzir a reincidência de cárie do que aquela placa formada sobre restaurações de amálgama. O S. sobrinus foi detectado na placa de seis indivíduos, sendo sua porcentagem relacionada ao total de streptococcus, maior nas restaurações de amálgama comparadas às de ionômero, sugerindo que a proporção de diferentes espécies de streptococcus pode diferir na placa de diferentes materiais restauradores.

FORSS $^{23}$ et al., em 1991, compararam os níveis de flúor e o crescimento de streptococcus mutans em restaurações. Vinte e um adultos entre 23 e 58 anos, que recebiam flúor na água de abastecimento (1ppm) e usavam dentifrício fluoretado, serviram como 
voluntários e durante o estudo foram aconselhados a manterem a dieta e os hábitos de higiene bucal. Amostras de placa foram coletadas de túneis deixados sob brackets fixados aos dentes, com ionômero de vidro (Ketac Fil) e compósito (Silar), em períodos de 14, 28 e 42 dias após a fixação. A placa foi encubada em ágar sanguis e MSB anaerobicamente a $37^{\circ} \mathrm{C}$, por 48 horas, quando então era feita a contagem do número de unidades formadoras de colônia (CFU). A quantidade de flúor na placa foi medida com um eletrodo específico para flúor, e o conteúdo de proteína, utilizado para acessar a quantidade de placa coletada, foi determinado pela hidrólise da proteína usando um detector de fluorescência. Os resultados mostraram que a quantidade de placa formada foi semelhante entre os materiais, porém o nível de flúor na placa desenvolvida sobre o ionômero de vidro foi muito mais alto do que aquele que se desenvolveu sobre o compósito, e este fato parece afetar o nível de streptococcus mutans na placa dental, pois simultaneamente à diminuição natural da liberação de flúor até um nível constante, ocorreu um aumento no crescimento bacteriano.

PALENIK $^{78}$ et al., em 1992, observaram os efeitos de quatro ionômeros de vidro restauradores (Fuji Cap II, Ketac Fil, Ketac Silver e Fuji Miracle Mix) e dois forradores (Vitrebond e XR-Glass lonomer) no crescimento e aderência da placa formada por cinco tipos de bactérias 
(Actinomyces viscosus, Streptococcus mitis, Streptococcus mutans, Lactobacillus casei e Streptococcus sanguis) responsáveis pela cárie primária e secundária ou pela formação de placa em humanos. Foram confeccionados dez corpos de prova de $5 \mathrm{~mm}$ de diâmetro e $2 \mathrm{~mm}$ de espessura em matrizes de teflon, de cada material, para os experimentos de inibição direta e indireta do crescimento bacteriano. No primeiro ensaio, os corpos de prova foram imersos em ágar de crescimento seletivo, inoculado com microrganismos, e a zona de inibição foi medida em milímetros. No segundo ensaio, os corpos de prova permaneceram em ágar, a $37^{\circ} \mathrm{C}$, por 48 horas, quando foram removidos e descartados, a seguir o meio de cultura foi inoculado e a zona de inibição medida também em milímetros. Cinco corpos de prova foram inoculados individualmente em tubos contendo $2 \mathrm{ml}$ de soro estéril, onde permaneceram por 1, 8, 24, 72 e 168 horas. Após cada período, $1 \mathrm{ml}$ foi removido, tamponado e, com o auxílio de um eletrodo, foi medida a quantidade de flúor liberado. Também foi medido o pH da solução remanescente. Incisivos centrais de bovinos foram utilizados para o teste de adesão bacteriana. Foram preparadas duas cavidades com $5 \mathrm{~mm}$ de diâmetro e $2 \mathrm{~mm}$ de profundidade em cinco dentes, para cada um dos quatro materiais restauradores. Após esterelizados, os dentes foram restaurados (alguns dentes não foram restaurados e funcionaram como controle) e imersos em tubos com 
meios de cultura e sacarose inoculados com S. mutans, por 24 horas a $37^{\circ} \mathrm{C}$. Após repetir todo o processo duas vezes, os dentes foram lavados com soro e a placa evidenciada com fuccina básica. A quantidade de placa recebeu um escore de 0 a 4 , dependendo da superfície ocupada, bem como um escore de 0 a 3 , referente a espessura. Os autores concluíram que todos os ionômeros avaliados demonstraram um efeito inibidor sobre o crescimento e a adesão de bactérias da cavidade bucal envolvidas na reincidência de cárie dentária. Houve alguma diferença da extensão da inibição bacteriana em função do material, do teste e da bactéria utilizada. A inibição do crescimento bacteriano pode estar relacionada com a quantidade liberada de flúor e essa quantidade necessária pode ser variável entre os organismos. Devido ao fato do teste de inibição do crescimento bacteriano ocorrer em 72 horas, os materiais que possuem uma rápida liberação de flúor foram os mais eficazes. A redução da aderência bacteriana pode estar relacionada ao baixo $\mathrm{pH}$ inicial do material, ou à sua liberação de flúor ou prata. 
3. Proposição 


\section{PROPOSIÇÃO}

Os materiais destinados ao selamento possuem características próprias, de modo que quando submetidos às diferentes intensidades de abrasividade dos dentifrícios durante a escovação, respondem diferentemente no que se refere ao desgaste e à rugosidade. Considerando esse fato, o presente estudo tem por objetivo avaliar a abrasão (por perda de massa) e rugosidade superficial de três tipos de cimentos de ionômero de vidro utilizados para selamento (um deles utilizado com sua proporção modificada) e um selante resinoso submetidos, in vitro, à escovação simulada utilizando-se dois diferentes tipos de dentifrícios. 
4. MATERIAL E MÉtodos 


\section{MATERIAL E MÉTODOS}

\section{1-MATERIAL}

\subsection{1- Cimentos de lonômero de Vidro}

Para realização deste trabalho foram selecionadas três marcas comerciais de cimento de ionômero de vidro, utilizadas no selamento de fossas e fissuras. As marcas utilizadas, fabricantes, indicação, natureza e classificação estão especificados na Tabela 1 (Figura 1Página 82).

TABELA 1 - Cimentos de lonômero de Vidro pesquisados

\begin{tabular}{llll}
\hline Marca & Fabricante & Natureza Indicação & Classificação
\end{tabular}

GC Fuji Plus GC América Modificado Cimentação Tipo I por resina

Ketac Molar ESPE Convencional Restauração Tipo II

Vitremer 3M Dental Modificado Restauração Tipo II por resina 


\subsection{2- Sistema de Selante Resinoso}

Foi empregado apenas um tipo de selante resinoso, como grupo controle, sendo este sem carga, com reação de ativação química, constituindo-se de dois frascos, um correspondente à resina universal e o outro à resina catalisadora. A marca comercial, o fabricante e o tipo de polimerização estão descritos na Tabela 2 (Figura2-Página82).

TABELA 2 - Selante Resinoso utilizado como controle

\begin{tabular}{lll}
\hline Marca & Fabricante & Polimerização
\end{tabular}

Delton

Dentsply Brasil

Química

\subsection{3- Silicona Industrial, Resina Acrílica e Liga Metálica}

A silicona industrial (RTV - 3110/Reforplás) foi utilizada para obtenção de um molde destinado à confecção dos corpos de prova em função da sua boa estabilidade dimensional e exatidão de reprodução. Inicialmente, confeccionou-se um cilindro de resina acrílica Duralay (Reliance Dental MFG Company) com 5mm de diâmetro e $3 \mathrm{~mm}$ de espessura (medida requerida futuramente para os 
corpos de prova), posteriormente, o mesmo foi fundido com a liga metálica Duracast (Odonto Comercial Importadora Ltda). Um cilindro de plástico oco foi preenchido com a silicona, seguindo-se as recomendações do fabricante para sua manipulação. Em seguida, o cilindro metálico, anteriormente fundido, foi pressionado contra a silicona, aguardou-se o tempo necessário para presa do material, e após a retirada da peça metálica de posição, obteve-se um molde nas mesmas dimensões do cilindro (Figura 3-Página 82).

\subsection{4- Tiras de Poliester e Lâminas de Vidro}

Tiras de poliester Odahcam (Herpo Produtos Dentários Ltda) foram utilizadas sobre os corpos de prova após o preenchimento do molde com os materiais. Para obtenção de superfícies lisas e planas foram colocadas lâminas de vidro (Perfecta Ind. E Com. de Lâminas de Vidro Ltda) sobre as tiras de poliester (Figura 4-Página 82).

\subsection{5- Esmalte de Unha Incolor e Finishing Gloss}

Esses materiais foram usados para proteger os cimentos de ionômero de vidro contra o ganho e perda de água. O esmalte usado 
foi da marca Maybelline ${ }^{101}$ (express finish) e o Finishing Gloss da 3M é o protetor feito para ser utilizado com o Vitremer (Figura 5-Página 82).

\subsection{6- Sonda Exploradora e Pinça Clínica}

Foi utilizada uma sonda exploradora número 5 (marca Duflex) para auxiliar na remoção dos corpos de prova de dentro da matriz e uma pinça clínica (marca Duflex) para segurar os espécimes durante seu manuseio.

\subsection{7- Matriz de Latão}

Utilizada no ensaio de desgaste para alojar os corpos de prova, possuindo as seguintes dimensões: $87 \mathrm{~mm}$ de comprimento, $27 \mathrm{~mm}$ de largura e $8 \mathrm{~mm}$ de altura. $\mathrm{Na}$ base inferior, havia duas concavidades para que pudesse ocorrer seu encaixe à máquina de escovação e na superfície superior havia duas perfurações com dimensões ligeiramente maiores que a dos corpos de prova para que os mesmos ficassem alojados no interior da matriz sem, no entanto, sofrer qualquer tipo de movimento. Foram confeccionadas seis matrizes em uma oficina especializada, sendo utilizadas nos dez ensaios realizados, devido ao seu baixo desgaste (Figuras 6 e 7-Página 83). 


\subsection{8- Cera Utilidade}

A cera utilidade (marca Epoxiglass) foi empregada para melhor adaptação da matriz de latão ao recipiente da máquina de escovação (Figura 6 e 7-Página 83).

\subsection{9- Dentifrícios}

Para o desgaste da superfície dos materiais estudados utilizaram-se dois tipos de dentifrício, como consta na Tabela 3 adiante, juntamente com o nome comercial, fabricante, classificação e média do número de tubos por ensaio de escovação.

TABELA 3 - Dentifrícios utilizados

\begin{tabular}{llll}
\hline Marca & Fabricante & Classificação & № de tubos \\
\hline Sorriso & Kolynos Brasil & Creme Dental & 4 de $90 \mathrm{~g}$ \\
Tandy & Kolynos Brasil & Gel Dental & 6 de $50 \mathrm{~g}$ \\
\hline
\end{tabular}

Fórmula básica do creme dental Sorriso: 1.500 ppm de flúor, sorbitol, caboximetilcelulose, carbonato de cálcio, lauril sulfato de sódio, sacarina sódica, composição aromática e água desmineralizada. Fórmula básica do gel dental, segundo o fabricante 
de baixa abrasividade, Tandy: 1.100 ppm de flúor, sorbitol, sílica, lauril sulfato de sódio, polietilenoglicol, caboximetilcelulose, sacarina sódica, composição aromática, corantes: vermelho, azul e água (Figuras 8,9,10 e 11-Página 83).

\subsubsection{0- Indicador Universal de pH}

Material da marca Merck (Alemanha) utilizado para medir o $\mathrm{pH}$, composto por uma escala comparativa de valores padronizados através de cores e uma tira que indicará o ph, devendo ser imersa na solução por um a dez minutos.

\subsubsection{1- Escova Dental}

A escova utilizada foi a Colgate Classic Infantil (ColgatePalmolive, Divisão da kolynos do Brasil) anatômica com cerdas duráveis com pontas arredondadas, de consistência macia suave. Sua composição básica é: material plástico, âncora metálica, nylon e pigmento atóxico (Figura 12-Página 83).

\subsubsection{2 - Toalha de Papel}

A toalha de papel Kleenex-Brand $(\mathrm{K}>\mathrm{C}>$ do Brasil da marca Kimberlay-Clark Corp.) foi empregada para secar os corpos de prova. 


\subsubsection{3- Seringa Luer Lock}

Seringa milimetrada em 5ml (marca Ibras/Brasil), foi utilizada para colocação da diluição de dentifrício durante o teste de escovação.

\subsubsection{4- Seringa Centrix}

A seringa centrix (marca DFL/Brasil) foi utilizada na confecção dos corpos de prova de cimento de ionômero de vidro, para evitar a formação de bolhas, permitir melhor acesso à matriz e proteger o material contra a luz.

\subsubsection{5- Espátula de Plástico}

Espátula especialmente fabricada (GC) para mistura de materiais ionoméricos.

\subsubsection{6- Microbrush}

Utensílio (marca KG Sorensen) utilizado para inserção do selante resinoso (Delton) na matriz de confecção dos corpos de prova. 


\subsubsection{7- Aparelho Fotopolimerizador}

O aparelho fotopolimerizador por luz halógena é constituído de uma fonte luminosa, com filtro apropriado para selecionar a variação do comprimento da onda transmissora e um guia luminoso, onde a luz pode ser levada à empunhadura (caneta), por um cabo. As unidades emitem luz em comprimento, no limite de 400-600 nanômetros, esses valores eram sempre verificados, anteriormente a utilização do aparelho, por meio de um Radiômetro (Gnatus). Neste experimento foi utilizado um aparelho Optilight 600 (Gnatus - Equipamentos Médicos Odontológicos Ltda) (Figura 13-Página 84).

\subsubsection{8- Estufa}

Também denominada de controlador microprocessado, (marca FANEM-São Paulo/Brasil) modelo 502 C, foi utilizada para armazenar à temperatura de $37^{\circ} \mathrm{C}$ os recipientes plásticos, preenchidos por água destilada, contendo os corpos de prova.

\subsubsection{9- Balança Eletrônica}

Foram utilizados dois tipos de balança eletrônica ambas Mettler Toledo (Switzerland), uma delas, modelo AB 204, com quatro casas decimais de precisão, foi utilizada para obter as medidas dos corpos 
de prova (Figura 14-Página 84), a outra, modelo PB 303, com três casas decimais, foi usada para medir e manter a proporção da quantidade de pó e líquido dos ionômeros testados.

Além disso, para diluição do dentifrício, a quantidade de água destilada necessária foi medida através de um Becker de vidro milimetrado, e a quantidade de dentifrício foi medida por uma balança Sauter (Switzerland), modelo K. 1200.

\subsubsection{0- pHmetro}

Aparelho preciso de medição do pH, modelo B 371 (marca Micronal). Possui uma haste de vidro contendo o mecanismo de detecção do pH e quando imersa na solução indicará o valor em um visor acoplado.

\subsubsection{1- Máquina de Escovação}

Esta Máquina, idealizada para realizar testes de abrasão por escovação em laboratório (confeccionada no Departamento de Materiais Dentários da FOB-USP sendo pertencente ao mesmo), constitui-se de uma base metálica sólida e pesada sobre a qual existem seis recipientes metálicos que apresentam a forma de tronco de pirâmide com base retangular, com $25 \mathrm{~mm}$ de largura na base, 
$40 \mathrm{~mm}$ no topo, $100 \mathrm{~mm}$ de comprimento e $25 \mathrm{~mm}$ de altura, onde serão escovados os corpos de prova, posicionados em uma matriz de latão, já descrita que serão encaixadas nos recipientes.

Sobre a base metálica existe também um motor que é ligado por meio de uma chave conectora, recebendo uma corrente elétrica alternada de 110 volts que, por meio de um sistema de uma correia e duas polias, coloca em movimento um virabrequim. Quatro barras cilíndricas, duas em cada lado do virabrequim, são unidas a este, sendo que por um lado e pelo outro existem outras barras (braços) as quais se fixam três suportes do lado direito e três do lado esquerdo para o encaixe das escovas. Cada braço apresenta um dispositivo na sua extremidade que permite a fixação da ponta ativa de uma escova dental através de dois parafusos, enquanto a outra extremidade mantém-se fixa ao eixo principal seguindo os seus movimentos.

As duas barras movimentadas pelo virabrequim, acionam as escovas em uma só direção e em dois sentidos, com uma amplitude de deslocamento de $3,8 \mathrm{~cm}$ e com pressão de $200 \mathrm{~g}$. A extremidade que mantém fixa a escova dental fica alojada no interior de uma das cubas metálicas, sendo que a posição das cerdas foi ajustada paralelamente à matriz, destinadas a receber o corpo de prova.

Para o registro do número de movimentos, um conta-giros padrão foi fixado sobre a base da máquina sendo mesmo ativado por 
uma haste ligada ao suporte da escova. A velocidade de escovação é de 374 ciclos por minuto, entendendo-se como ciclo, o movimento completo de vaivém da escova dental ${ }^{20}$ (Figuras 17,18, 19-Página 85).

\subsubsection{2- Aparelho de Ultra-Som}

O aparelho de vibração ultra-sônica (marca Unique-Odonto Brás), modelo T 50110 foi utilizado, durante dez minutos, para promover a limpeza dos corpos de prova, removendo as partículas abrasivas remanescentes da pasta dental.

\subsubsection{3- Rugosímetro}

Para leitura da rugosidade da superfície dos corpos de prova foi utilizado o Rugosímetro Hommel Tester T 1000 (Hommelwerke, Gmbh, Alte Tuttinger Strebe 20.D-7730 VS-Schwenningen), aparelho de avaliação de alta sensibilidade, com uma ponta apalpadora esférica que percorre a superfície e é acoplado a uma unidade que processa e interage as informações quantitativamente. O resultado é registrado de imediato, digitalmente em um visor de cristal líquido (Figuras 15 e 16-Página 84). 


\section{2- MÉTODOS}

\subsection{1- Confecção dos Corpos de Prova}

Foi confeccionado um total de 140 corpos de prova sendo, 28 de cada grupo analisado: Delton, Ketac Molar, GC Fuji Plus, sendo que o Vitremer foi utilizado em dois grupos, um na proporção recomendada pelo fabricante e outro numa proporção modificada ${ }^{50}$, diluída. Havia um excedente de quatro corpos de prova de cada grupo, para o caso de uma eventual perda durante o experimento. Os grupos de materiais estudados, a proporção pó líquido, o tempo de manipulação e o tempo de presa estão ilustrados na Tabela 4.

TABELA 4 - Divisão dos grupos e Informações necessárias para confecção dos corpos de prova

\begin{tabular}{lllll}
\hline Grupo & Proporção & Mistura & Trabalho & Presa \\
\hline Fuji Plus & $2,0 \mathrm{gP} / 1,0 \mathrm{gL}$ & $30 \mathrm{seg}$. & $2 \mathrm{~min}$. & $4 \mathrm{~min}$. \\
Ketac Molar & $3,0 \mathrm{gP} / 1,0 \mathrm{gL}$ & $45 \mathrm{seg}$. & $3 \mathrm{~min}$. & $5 \mathrm{~min}$. \\
Vitremer & $2,5 \mathrm{gP} / 1,0 \mathrm{gL}$ & $45 \mathrm{seg}$. & $3 \mathrm{~min}$. & $4 \mathrm{~min}$. \\
Vitremer $1 / 4$ & $0,625 \mathrm{gP} / 1,0$ & $45 \mathrm{seg}$. & $3 \mathrm{~min}$. & $4 \mathrm{~min}$. \\
& $\mathrm{gL}$ & & & \\
& & & & \\
Delton & & & & \\
\end{tabular}


Para os grupos de cimento de ionômero de vidro, determinadas quantidades de pó e de líquido foram pesadas em uma balança eletrônica (com três casas decimais após a vírgula), para se ter um valor constante da relação pó/líquido, seguindo as proporções em peso recomendada pelo fabricante de cada produto em virtude da importância da padronização desta variável.

Posteriormente, foram misturados e manipulados, em meio ambiente refrigerado de $23^{\circ} \mathrm{C} \pm 1^{0} \mathrm{C}$ e umidade relativa controlada de $50 \%$, por meio de um desumidificador. Para a espatulação, foram utilizadas espátulas de plástico e o bloco de mistura fornecido pelo fabricante. Imediatamente após a mistura, o material foi injetado no interior da matriz, com a seringa tipo Centrix, até seu completo preenchimento. Com intuito de se obter superfícies lisas e planas os materiais foram cobertos por uma tira de poliester e por cima uma lâmina de vidro. O conjunto recebeu uma moderada pressão digital a fim de delimitar a espessura do espécime. Os cimentos ionoméricos quimicamente ativados (Ketac Molar e Fuji Plus) foram mantidos no interior da matriz e cobertos até o término do tempo relativo à reação de presa inicial do material. Para o Vitremer, em ambas as proporções, por ser um CIV modificado por resina, foi realizada a fotopolimerização de 60 segundos de cada lado do corpo de prova, utilizando-se uma unidade polimerizadora de luz visível. Os corpos de 
prova foram removidos cuidadosamente da matriz com o auxílio de uma sonda exploradora, sem danificá-los.

Imediatamente após a remoção de dentro da matriz, os materiais foram protegidos contra a sinérise e embebição e para tal, nos grupos de Vitremer aplicou-se com um pincel, uma fina camada de Finishing Gloss (protetor fornecido pelo próprio fabricante- 3M) em toda extensão do corpo de prova e seguiu-se a fotopolimerização por 20 segundos de cada lado; e nos grupos de materiais do Ketac Molar e Fuji Plus utilizou-se esmalte de unha incolor ${ }^{101}$, também certificandose de que toda extensão do material havia sido protegida.

A confecção dos corpos de prova do Grupo Delton (selante resinoso), foi diferente dos outros grupos, pois não foi possível a pesagem do material, devido ao risco de evaporação pelo fato dos seus componentes serem líquidos. Em uma cápsula para mistura, presente no kit do material colocaram-se duas gotas de resina universal e duas gotas de resina catalisadora, misturando-se por dez segundos com o auxílio de uma espátula plástica fornecida pelo fabricante. Após o preenchimento da matriz com o material, utilizandose uma ponta microbrush, para evitar a formação de bolhas, este foi coberto com a tira de poliester e a lâmina de vidro por dois minutos, tempo este necessário para sua polimerização. 
Os corpos de prova foram acondicionados em recipientes plásticos escuros, após 24 horas, em 100\% de umidade (água destilada), individualizados e identificados, sendo então, armazenados em temperatura ambiente controlada de $37^{\circ} \mathrm{C}$, através de estufa.

\subsection{2- Determinação da Massa Inicial}

Os corpos de prova foram retirados de seus frascos, secos em toalha de papel por 30 segundos e pesados, os valores obtidos eram anotados em papel apropriado. A cada intervalo de 24 horas, uma nova pesagem era efetuada até que não houvesse alteração da massa da amostra provocada pela embebição. Quando se obteve um valor constante, variação de no máximo $0,0002 \mathrm{~g}$, após cinco pesagens consecutivas, este foi registrado como valor inicial $\left(M_{1}\right)$. Depois de atingirem a massa inicial, os corpos de prova foram submetidos ao teste de escovação.

\subsection{3- Procedimentos de Desgaste}

Para realização dos testes de abrasão, foi utilizada uma máquina de escovação. Cada dois corpos de prova foram encaixados na matriz de latão, que por sua vez foi posicionada em recipientes metálicos fixados por parafusos à máquina. Utilizou-se cera utilidade 
cortada em tiras para promover uma perfeita adaptação e vedamento entre a matriz e o recipiente. Em cada ensaio foram utilizadas seis escovas adaptadas, separando-se a parte ativa de seu cabo, para que pudessem ser parafusadas ao suporte do braço da máquina e posteriormente posicionadas sobre os corpos de prova, paralelamente à superfície da matriz, de tal forma que as cerdas abrangessem todo o diâmetro dos corpos. O creme e o gel dental foram pesados e diluídos, no interior de um Becker, com água destilada na proporção de 1:2, ou seja, para cada $50 \mathrm{~g}$ de dentifrício utilizaram-se $100 \mathrm{ml}$ de água destilada. Através da seringa Luer Lock despejaram-se $5 \mathrm{ml}$ de mistura de pasta dentro do recipiente metálico onde se encontravam os corpos de prova sobre a matriz de latão, depois de tudo pronto acionou-se a máquina de escovação.

O teste foi realizado durante aproximadamente cinco horas, submetendo os corpos de prova a 100.000 ciclos de escovação, sendo considerado como ciclo o movimento completo de vaivém da escova dental. Para que não houvesse nenhuma variável, $5 \mathrm{ml}$ de solução de dentifrício era reposta a cada cinco minutos em todos os recipientes e a cada 17.000 ciclos os corpos de prova eram trocados aos pares numa ordem sucessiva do primeiro até o sexto recipiente, para que pudessem passar por todas as escovas. 


\subsection{4- Limpeza dos Corpos de Prova}

Após o término dos 100.000 ciclos de escovação, os corpos de prova eram removidos do interior da matriz, dentro dos recipientes metálicos e imediatamente lavados em água corrente, sendo seguros por uma pinça clínica. Em seguida, os mesmos foram colocados no interior de um aparelho de vibração ultra-sônica contendo água destilada onde permaneceram por um período de dez minutos, para a completa remoção das partículas abrasivas do dentifrício eventualmente incrustadas nos microporos da superfície ionomérica das amostras. Posteriormente, retornaram a ser armazenados no interior de frascos plásticos individualizados e conservados a $37^{\circ} \mathrm{C}$.

\subsection{5- Determinação da Massa Final}

Após o teste de escovação, os corpos de prova foram pesados utilizando-se a mesma balança eletrônica e a mesma técnica de secagem, usadas anteriormente para a obtenção da massa inicial, e os valores foram registrados. A cada 24 horas, uma nova pesagem foi efetuada até que não houvesse variação nos valores da massa das amostras em função da embebição. Quando se obteve um valor constante, após cinco pesagens consecutivas, este foi registrado como Massa Final $\left(\mathrm{M}_{2}\right)$. 


\subsection{6- Avaliação da Rugosidade Superficial}

A análise da superfície dos corpos de prova foi feita quantitativamente, através da utilização de um rugosímetro, antes e depois do teste de escovação, sempre após os materiais terem atingido massas constantes. Os corpos de prova foram cuidadosamente secos em papel toalha. Para cada superfície do corpo de prova foram realizadas cinco leituras, sempre aleatoriamente em lugares diferentes para abranger toda extensão, com a finalidade de avaliar não apenas no sentido onde houve a escovação mas também perpendicular a ele, para poder detectar os sulcos provocados por este ato.

A leitura considerada foi a média aritmética entre os picos e vales $\left(R_{a}-\mu m\right)$, percorrida pelo apalpador, num limite de tracejamento $\left(L_{T}\right)$ de $1,5 \mathrm{~mm}$ e com um cut off $\left(L_{C}\right)$ de $0,25 \mathrm{~mm}$. Sendo que a tolerância mínima ( $T_{\text {mínima }}$ considerada foi $0,01 \mu \mathrm{m}$ e a tolerância máxima ( $\left.T_{\text {máximo }}\right) 8,00 \mu \mathrm{m}$.

\subsection{7- Análise Estatística}

Os resultados obtidos foram submetidos à Análise de Variância a dois critérios. A comparação individual das médias, foi feita pelo Teste de Tukey, em nível de 5\% de probabilidade. 


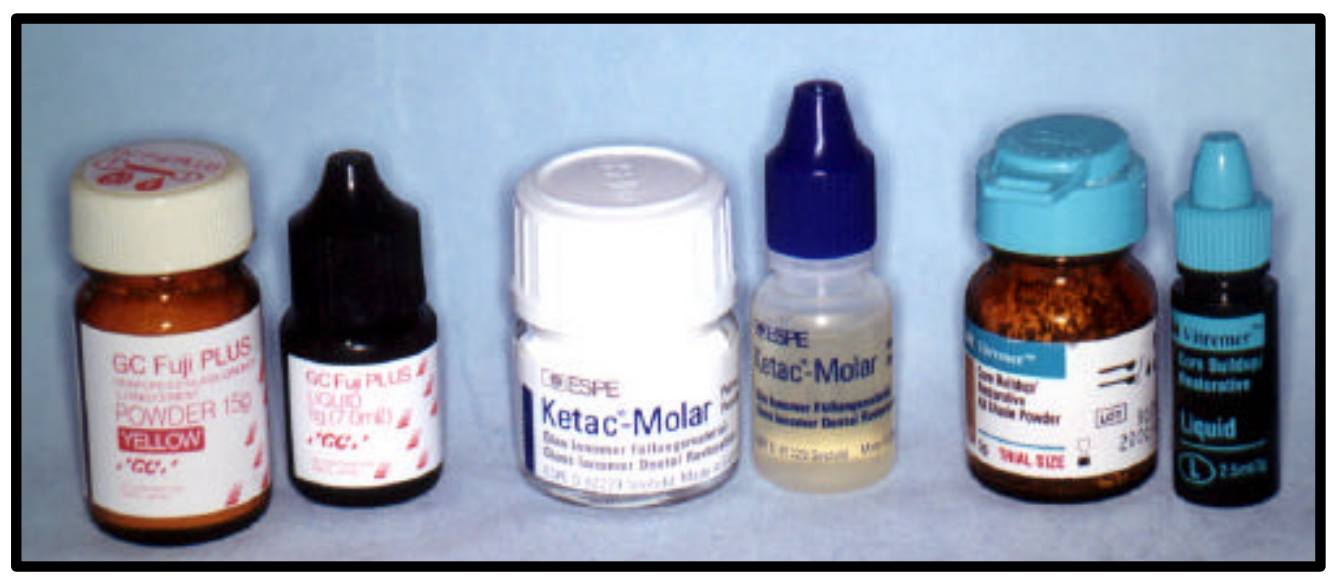

FIGURA 1- Apresentação comercial dos Cimentos de lonômero de Vidro pesquisados, respectivamente: GC Fuji Plus, Ketac Molar e Vitremer

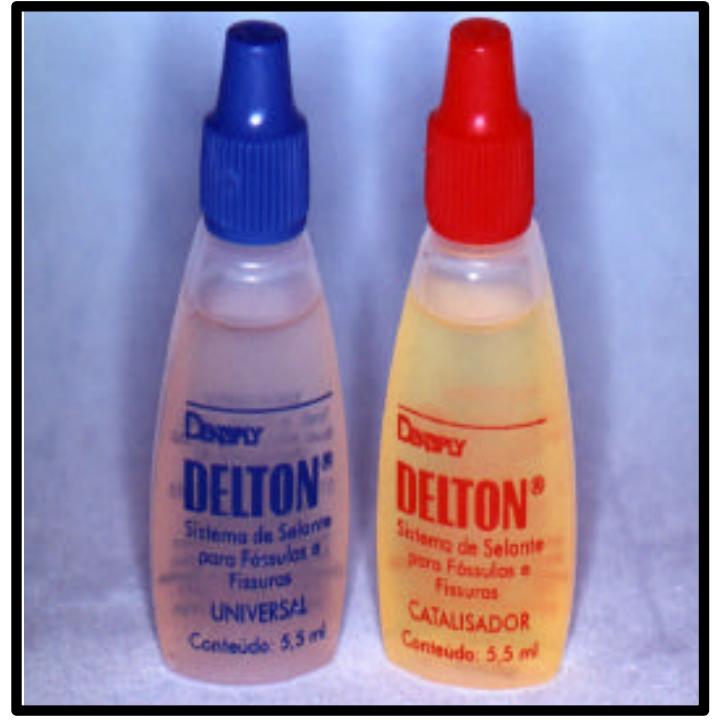

FIGURA 2- Apresentação comercial do selante resinoso, Delton, utilizado como controle

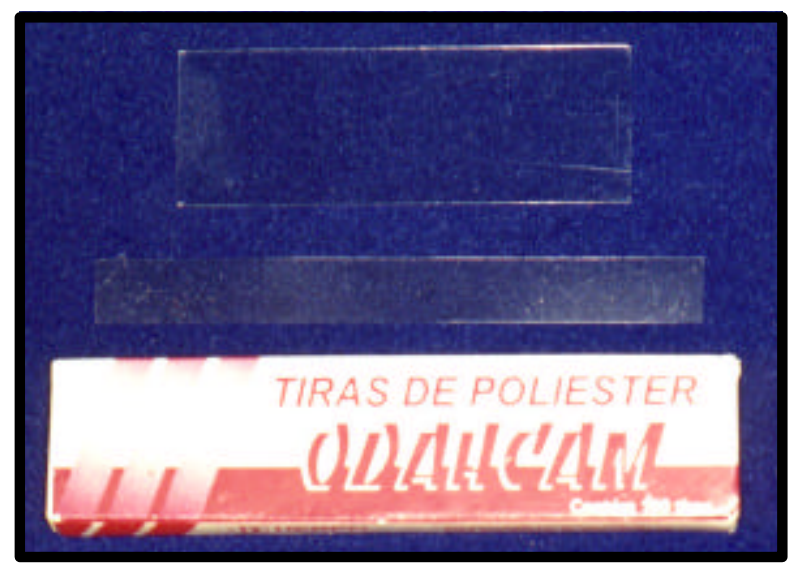

FIGURA 4- Tira de poliéster e lâmina de vidro, materiais auxiliares na confecção dos corpos de prova

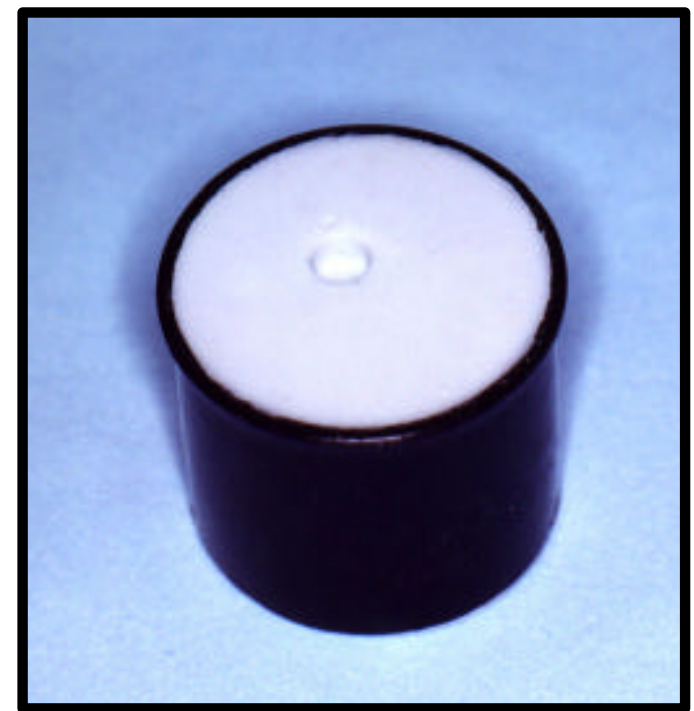

FIGURA 3- Molde destinado à confecção dos corpos de prova

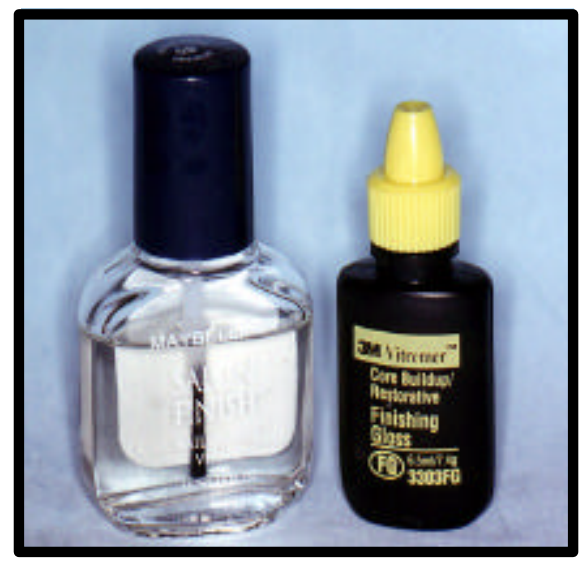

FIGURA 5- Esmalte de unha incolor e Finishing Gloss, protetores ionoméricos utilizados 


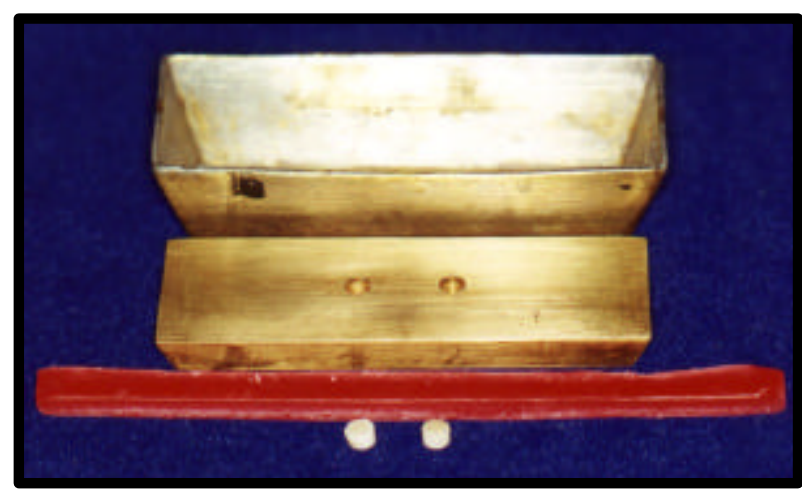

FIGURA 6- Recipiente da máquina de escovação, matriz de latão, tira de cera utilidade e corpos de prova

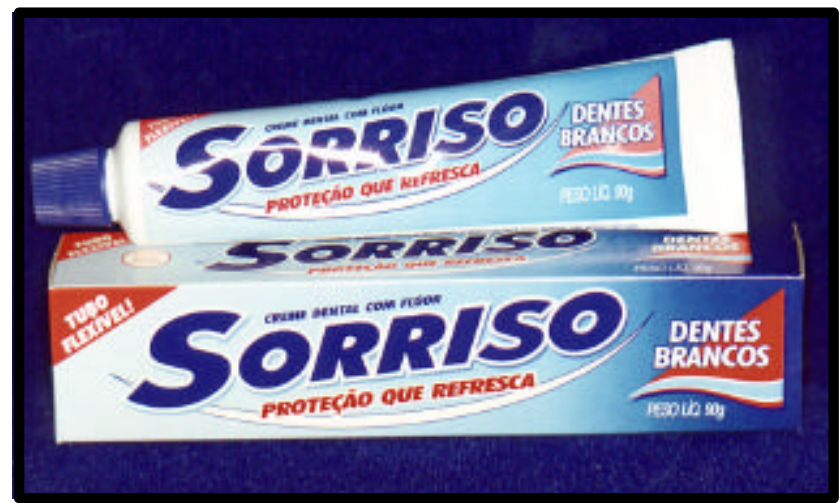

FIGURA 8- Apresentação comercial do dentifrício Sorriso

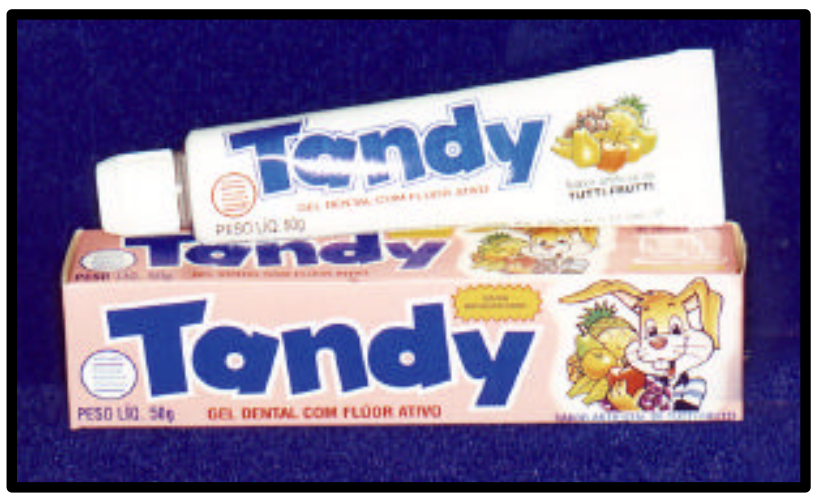

FIGURA 10 - Apresentação comercial do dentifrício Tandy

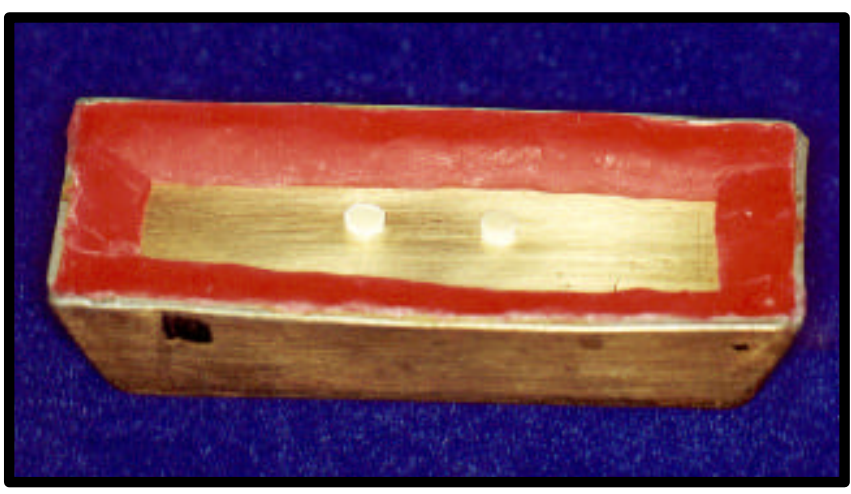

FIGURA 7- Posicionamento dos materiais da figura 6 para realização do teste de escovação

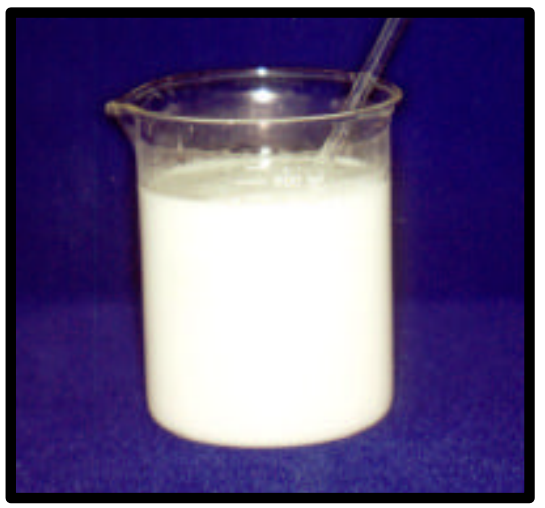

FIGURA 9- Dentifrício Sorriso Diluído

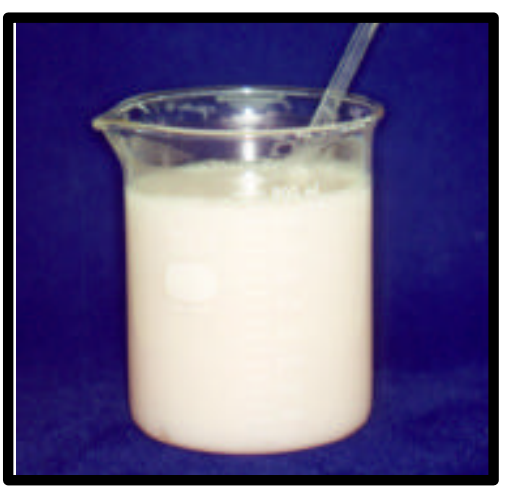

FIGURA 11- Dentifrício Tandy Diluído

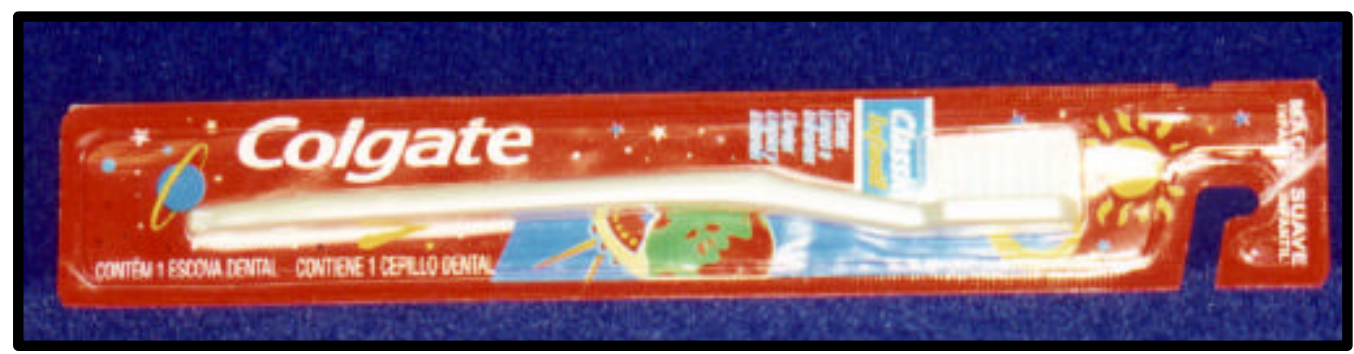

FIGURA 12- Apresentação comercial da escova dental 


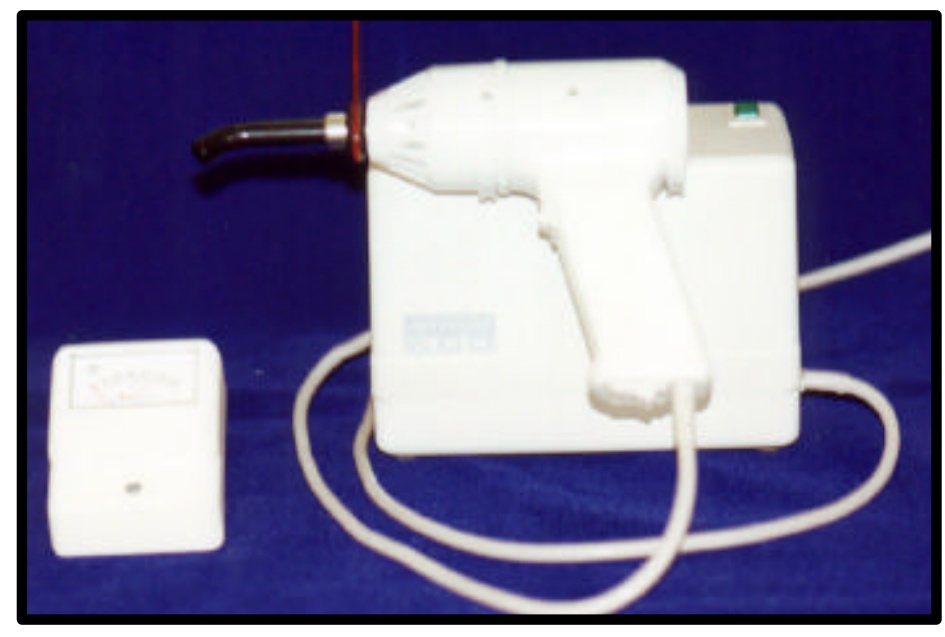

FIGURA 13- Aparelho fotopolimerizador Optilight 600 e radiômetro da Gnatus

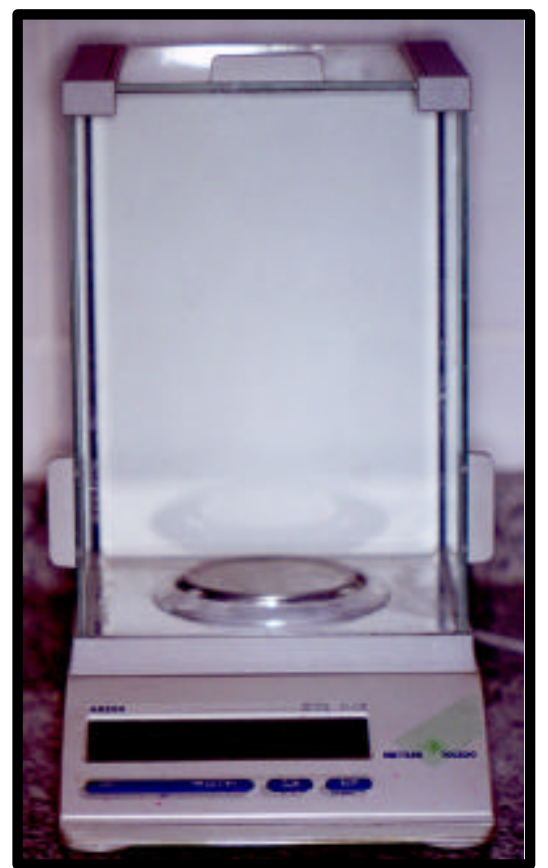

FIGURA 14 - Balança eletrônica de precisão, Mettler Toledo, modelo AB 204.Utilizada para pesar os corpos de prova

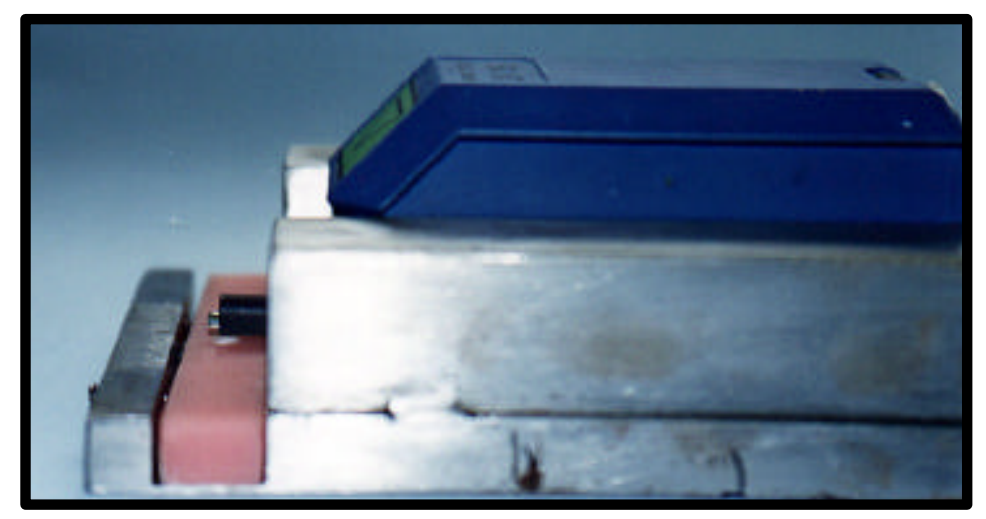

FIGURA 15- Rugosímetro Hommel Tester T 1000, ponta apalpadora percorrendo o corpo de prova para medição da rugosidade

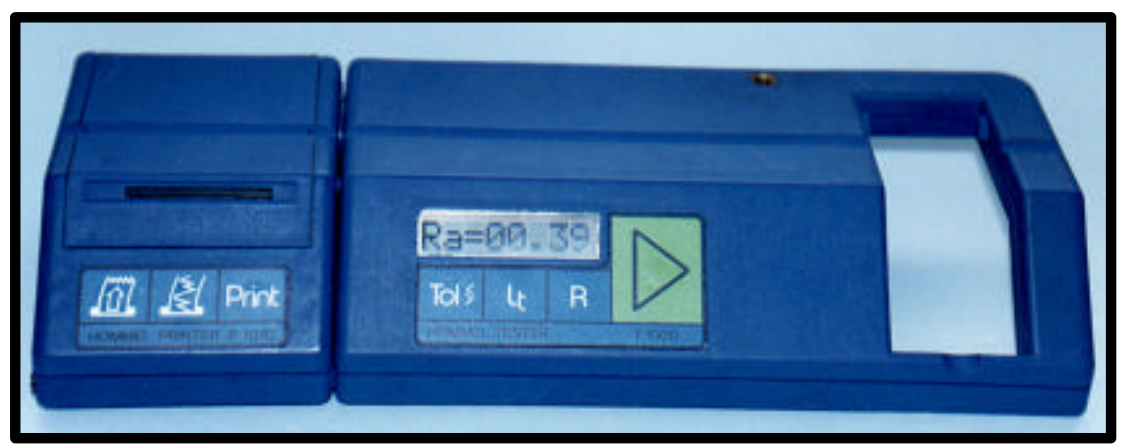

FIGURA 16- Rugosímetro Hommel Tester T 1000, visor e unidade de processo das informações 


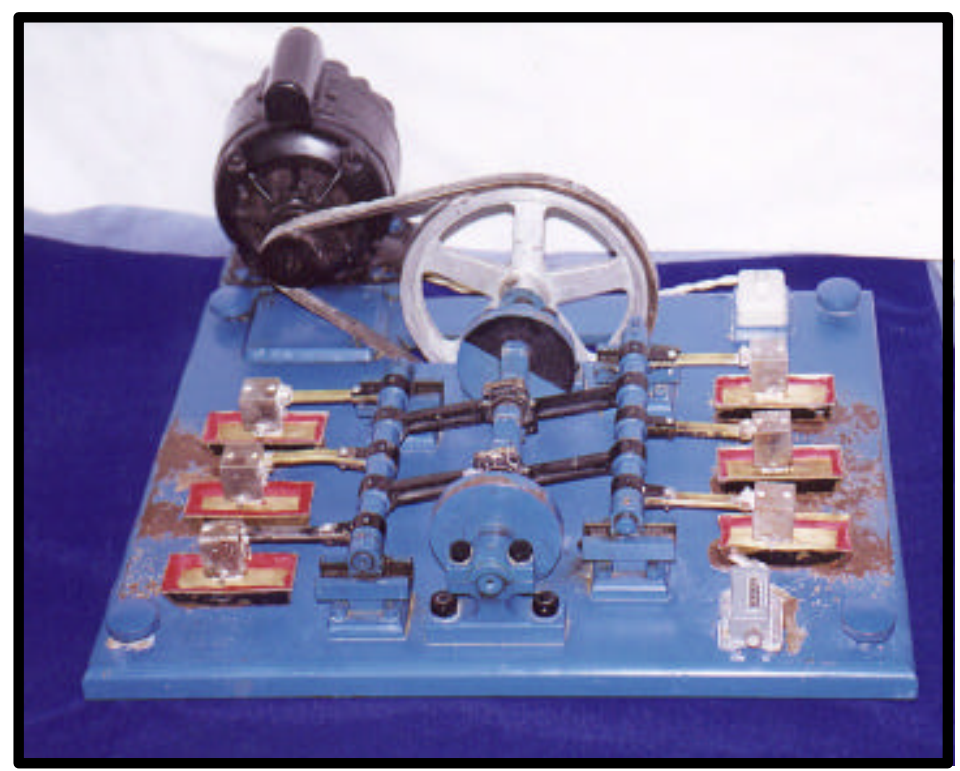

FIGURA 17- Máquina de escovação

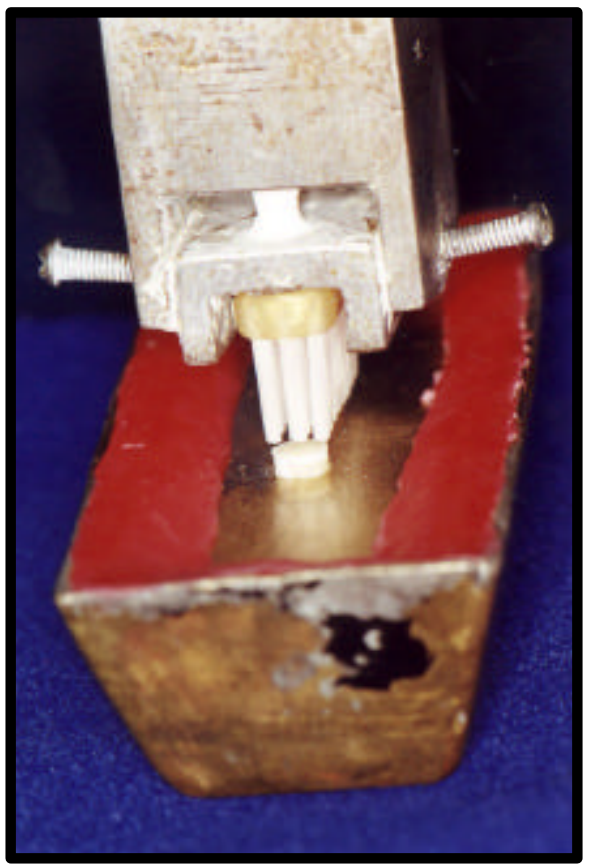

FIGURA 18- Vista lateral de um dos seis dispositivos da máquina onde os corpos de prova foram submetidos ao teste de escovação

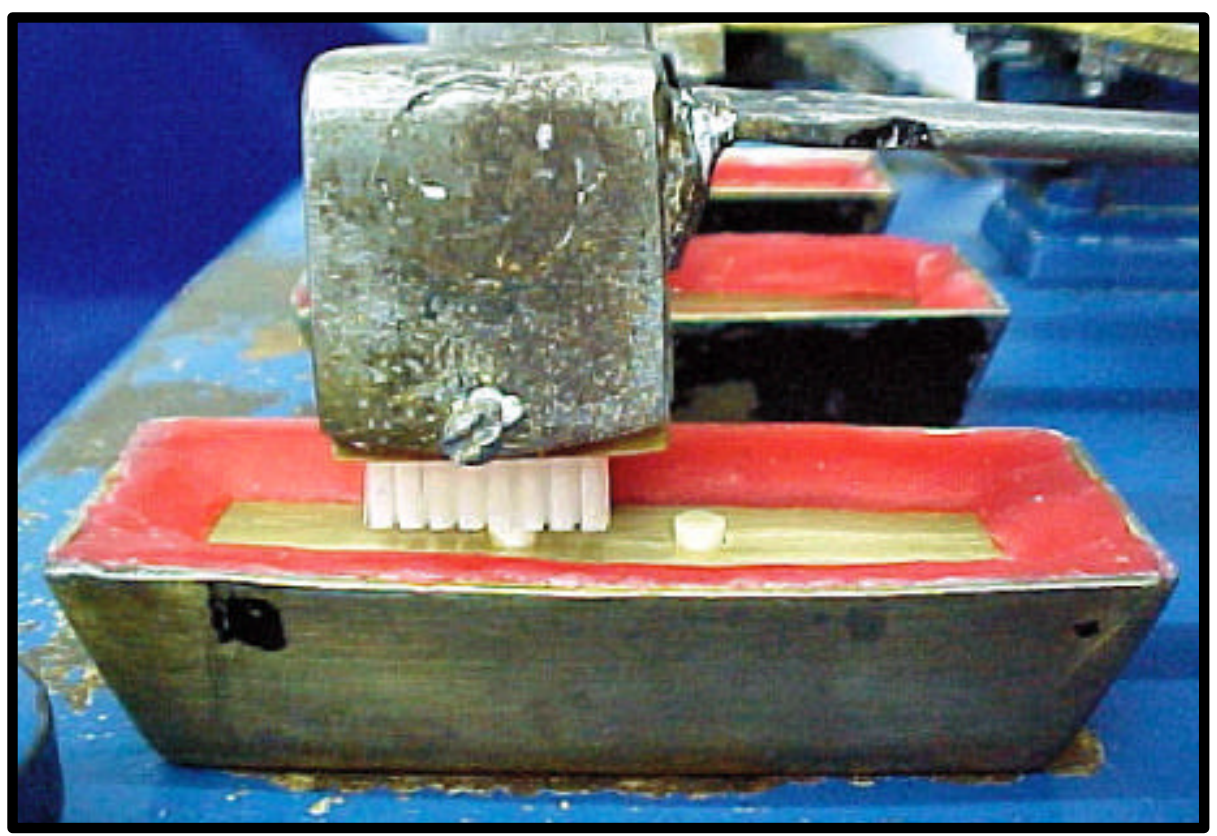

FIGURA 19 - Vista frontal de um dos seis dispositivos da máquina onde os corpos de prova foram submetidos ao teste de escovação 
5. Resultados 


\section{RESULTADOS}

\section{1- DESGASTE}

Os valores do desgaste, provocado pela escovação, foram obtidos pela diferença de peso em gramas (expressa em percentual de perda), entre a massa inicial $\left(M_{1}\right)$ e a massa final $\left(M_{2}\right)$. Esses valores serão ilustrados na Figura 20 e mostrados nas Tabelas de número 5 a 9, respectivamente para os grupos: Delton, Ketac-Molar, GCFuji Plus, Vitremer e Vitremer Diluído 1/4, sendo que os corpos de prova de 1 a 12 foram escovados com o dentifrício Sorriso e os de 13 a 24 foram escovados com o dentifrício Tandy.

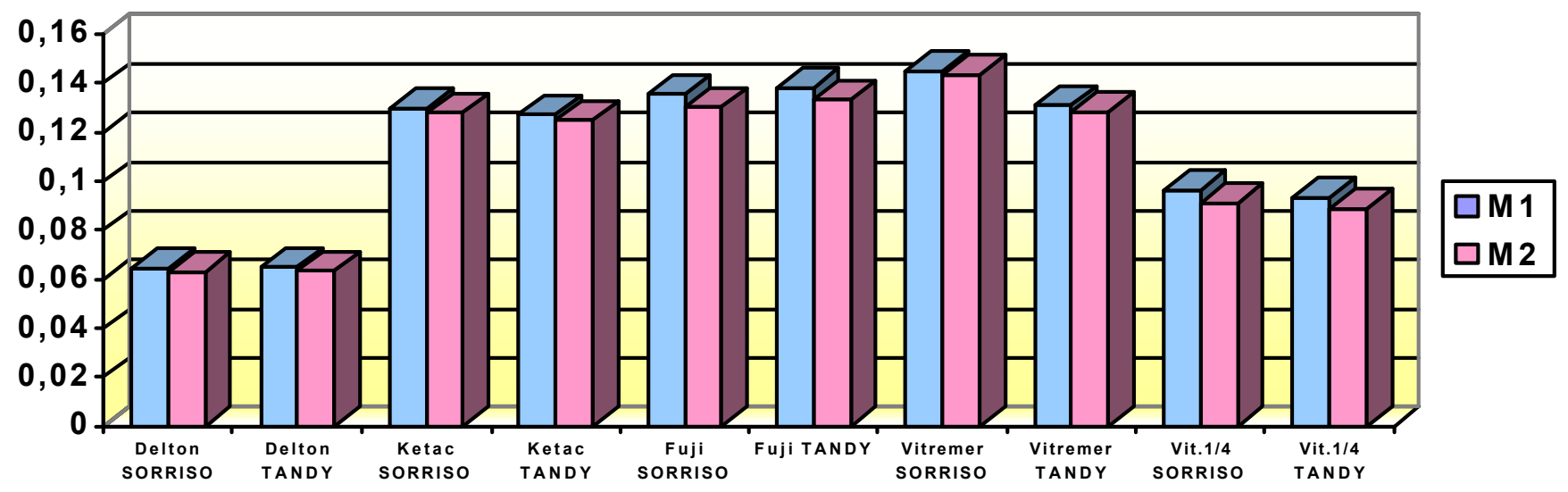

FIGURA 20 - Gráfico comparando as médias das massas inicial e final (em gramas) dos materiais testados utilizando dois diferentes dentifrícios (Sorriso e Tandy) 
TABELA 5- Massa inicial $\left(M_{1}\right)$, massa final $\left(M_{2}\right)$, diferença $\left(M_{1}-M_{2}\right)$ e percentagem de perda de massa para o selante resinoso Delton

\begin{tabular}{|c|c|c|c|c|c|}
\hline Pasta & $\begin{array}{l}\text { Corpos de } \\
\text { prova }\end{array}$ & $\begin{array}{c}\mathrm{M}_{1} \\
\text { gramas }\end{array}$ & $\begin{array}{c}M_{2} \\
\text { gramas }\end{array}$ & $\begin{array}{c}\left(M_{1}-M_{2}\right) \\
\text { gramas }\end{array}$ & $\%$ de perda \\
\hline & 1 & 0,0703 & 0,0694 & 0,0009 & 1,28023 \\
\hline & 2 & 0,0619 & 0,0598 & 0,0021 & 3,39257 \\
\hline$S$ & 3 & 0,0651 & 0,0642 & 0,0009 & 1,38249 \\
\hline $\mathrm{O}$ & 4 & 0,0706 & 0,0684 & 0,0022 & 3,11615 \\
\hline $\mathrm{R}$ & 5 & 0,0648 & 0,0640 & 0,0008 & 1,23457 \\
\hline $\mathrm{R}$ & 6 & 0,0651 & 0,0639 & 0,0012 & 1,84332 \\
\hline I & 7 & 0,0620 & 0,0608 & 0,0012 & 1,93548 \\
\hline$S$ & 8 & 0,0654 & 0,0642 & 0,0012 & 1,83486 \\
\hline \multirow[t]{7}{*}{ O } & 9 & 0,0607 & 0,0597 & 0,0010 & 1,64745 \\
\hline & 10 & 0,0577 & 0,0554 & 0,0023 & 3,98614 \\
\hline & 11 & 0,0624 & 0,0615 & 0,0009 & 1,44231 \\
\hline & 12 & 0,0674 & 0,0645 & 0,0029 & 4,30267 \\
\hline & 13 & 0,0664 & 0,0643 & 0,0021 & 3,16265 \\
\hline & 14 & 0,0649 & 0,0625 & 0,0024 & 3,69800 \\
\hline & 15 & 0,0658 & 0,0643 & 0,0015 & 2,27964 \\
\hline $\mathrm{T}$ & 16 & 0,0636 & 0,0620 & 0,0016 & 2,51572 \\
\hline$A$ & 17 & 0,0641 & 0,0628 & 0,0013 & 2,02808 \\
\hline $\mathrm{N}$ & 18 & 0,0637 & 0,0620 & 0,0017 & 2,66876 \\
\hline$D$ & 19 & 0,0658 & 0,0643 & 0,0015 & 2,27964 \\
\hline \multirow[t]{5}{*}{$\mathrm{Y}$} & 20 & 0,0661 & 0,0644 & 0,0017 & 2,57186 \\
\hline & 21 & 0,0668 & 0,0653 & 0,0015 & 2,24551 \\
\hline & 22 & 0,0649 & 0,0639 & 0,0010 & 1,54083 \\
\hline & 23 & 0,0641 & 0,0623 & 0,0018 & 2,80811 \\
\hline & 24 & 0,0645 & 0,0628 & 0,0017 & 2,63566 \\
\hline
\end{tabular}


TABELA 6- Massa inicial $\left(M_{1}\right)$, massa final $\left(M_{2}\right)$, diferença $\left(M_{1}-M_{2}\right)$ e percentagem de perda de massa para o cimento de iônomero de vidro Ketac-Molar

\begin{tabular}{|c|c|c|c|c|c|}
\hline Pasta & $\begin{array}{l}\text { Corpos de } \\
\text { prova }\end{array}$ & $\begin{array}{c}M_{1} \\
\text { gramas }\end{array}$ & $\begin{array}{c}\mathrm{M}_{2} \\
\text { gramas }\end{array}$ & $\begin{array}{c}\left(M_{1}-M_{2}\right) \\
\text { gramas }\end{array}$ & $\%$ de perda \\
\hline & 1 & 0,1401 & 0,1386 & 0,0015 & 1,07066 \\
\hline & 2 & 0,1382 & 0,1355 & 0,0027 & 1,95369 \\
\hline$S$ & 3 & 0,1282 & 0,1253 & 0,0029 & 2,26209 \\
\hline 0 & 4 & 0,1424 & 0,1407 & 0,0017 & 1,19382 \\
\hline $\mathrm{R}$ & 5 & 0,1324 & 0,1297 & 0,0027 & 2,03927 \\
\hline $\mathrm{R}$ & 6 & 0,1240 & 0,1219 & 0,0021 & 1,69355 \\
\hline I & 7 & 0,1394 & 0,1378 & 0,0016 & 1,14778 \\
\hline S & 8 & 0,1229 & 0,1212 & 0,0017 & 1,38324 \\
\hline \multirow[t]{7}{*}{0} & 9 & 0,1259 & 0,1246 & 0,0013 & 1,03257 \\
\hline & 10 & 0,1228 & 0,1205 & 0,0023 & 1,87296 \\
\hline & 11 & 0,1200 & 0,1184 & 0,0016 & 1,33333 \\
\hline & 12 & 0,1218 & 0,1202 & 0,0016 & 1,31363 \\
\hline & 13 & 0,1259 & 0,1237 & 0,0022 & 1,74742 \\
\hline & 14 & 0,1389 & 0,1364 & 0,0025 & 1,79986 \\
\hline & 15 & 0,1273 & 0,1253 & 0,0020 & 1,57109 \\
\hline $\mathrm{T}$ & 16 & 0,1297 & 0,1277 & 0,0020 & 1,54202 \\
\hline$A$ & 17 & 0,1299 & 0,1282 & 0,0017 & 1,30870 \\
\hline $\mathrm{N}$ & 18 & 0,1332 & 0,1316 & 0,0016 & 1,20120 \\
\hline$D$ & 19 & 0,1207 & 0,1185 & 0,0022 & 1,82270 \\
\hline \multirow[t]{5}{*}{$\mathrm{Y}$} & 20 & 0,1261 & 0,1241 & 0,0020 & 1,58604 \\
\hline & 21 & 0,1392 & 0,1368 & 0,0024 & 1,72414 \\
\hline & 22 & 0,1247 & 0,1229 & 0,0018 & 1,44346 \\
\hline & 23 & 0,1197 & 0,1169 & 0,0028 & 2,33918 \\
\hline & 24 & 0,1089 & 0,1059 & 0,0030 & 2,75482 \\
\hline
\end{tabular}


TABELA 7- Massa inicial $\left(M_{1}\right)$, massa final $\left(M_{2}\right)$, diferença $\left(M_{1}-M_{2}\right)$ e percentagem de perda de massa para o cimento de iônomero de vidro GC Fuji Plus

\begin{tabular}{|c|c|c|c|c|c|}
\hline Pasta & $\begin{array}{l}\text { Corpos de } \\
\text { prova }\end{array}$ & $\begin{array}{c}M_{1} \\
\text { gramas }\end{array}$ & $\begin{array}{c}\mathrm{M}_{2} \\
\text { gramas }\end{array}$ & $\begin{array}{c}\left(M_{1}-M_{2}\right) \\
\text { gramas }\end{array}$ & $\%$ de perda \\
\hline & 1 & 0,1295 & 0,1236 & 0,0059 & 4,55598 \\
\hline & 2 & 0,1260 & 0,1190 & 0,0070 & 5,55556 \\
\hline$S$ & 3 & 0,1316 & 0,1266 & 0,0050 & 3,79939 \\
\hline 0 & 4 & 0,135 & 0,1281 & 0,0069 & 5,11111 \\
\hline $\mathrm{R}$ & 5 & 0,1312 & 0,1267 & 0,0045 & 3,42988 \\
\hline $\mathrm{R}$ & 6 & 0,1374 & 0,1316 & 0,0058 & 4,22125 \\
\hline I & 7 & 0,1393 & 0,1344 & 0,0049 & 3,51759 \\
\hline$S$ & 8 & 0,1341 & 0,1295 & 0,0046 & 3,43028 \\
\hline \multirow[t]{7}{*}{ O } & 9 & 0,1347 & 0,1299 & 0,0048 & 3,56347 \\
\hline & 10 & 0,1362 & 0,1312 & 0,0050 & 3,67107 \\
\hline & 11 & 0,1394 & 0,1334 & 0,0060 & 4,30416 \\
\hline & 12 & 0,1509 & 0,1444 & 0,0065 & 4,30749 \\
\hline & 13 & 0,1347 & 0,1300 & 0,0047 & 3,48924 \\
\hline & 14 & 0,1329 & 0,1285 & 0,0044 & 3,31076 \\
\hline & 15 & 0,1393 & 0,1345 & 0,0048 & 3,44580 \\
\hline $\mathrm{T}$ & 16 & 0,1360 & 0,1316 & 0,0044 & 3,23529 \\
\hline$A$ & 17 & 0,1399 & 0,1349 & 0,0050 & 3,57398 \\
\hline $\mathrm{N}$ & 18 & 0,1467 & 0,1412 & 0,0055 & 3,74915 \\
\hline D & 19 & 0,1435 & 0,1374 & 0,0061 & 4,25087 \\
\hline \multirow[t]{5}{*}{ Y } & 20 & 0,1294 & 0,1259 & 0,0035 & 2,70479 \\
\hline & 21 & 0,1351 & 0,1312 & 0,0039 & 2,88675 \\
\hline & 22 & 0,1454 & 0,1402 & 0,0052 & 3,57634 \\
\hline & 23 & 0,1357 & 0,1310 & 0,0047 & 3,46352 \\
\hline & 24 & 0,1384 & 0,1341 & 0,0043 & 3,10694 \\
\hline
\end{tabular}


TABELA 8- Massa inicial $\left(M_{1}\right)$, massa final $\left(M_{2}\right)$, diferença $\left(M_{1}-M_{2}\right)$ e percentagem de perda de massa para o cimento de iônomero de vidro Vitremer

\begin{tabular}{|c|c|c|c|c|c|}
\hline Pasta & $\begin{array}{l}\text { Corpos de } \\
\text { prova }\end{array}$ & $\begin{array}{c}M_{1} \\
\text { gramas }\end{array}$ & $\begin{array}{c}\mathrm{M}_{2} \\
\text { gramas }\end{array}$ & $\begin{array}{c}\left(M_{1}-M_{2}\right) \\
\text { gramas }\end{array}$ & $\%$ de perda \\
\hline & 1 & 0,1501 & 0,1480 & 0,0021 & 1,39907 \\
\hline & 2 & 0,1443 & 0,1425 & 0,0018 & 1,24740 \\
\hline$S$ & 3 & 0,1477 & 0,1458 & 0,0019 & 1,28639 \\
\hline 0 & 4 & 0,1434 & 0,1416 & 0,0018 & 1,25523 \\
\hline $\mathrm{R}$ & 5 & 0,1496 & 0,1480 & 0,0016 & 1,06952 \\
\hline $\mathrm{R}$ & 6 & 0,1419 & 0,1402 & 0,0017 & 1,19803 \\
\hline I & 7 & 0,1477 & 0,1460 & 0,0017 & 1,15098 \\
\hline$S$ & 8 & 0,1456 & 0,1440 & 0,0016 & 1,09890 \\
\hline \multirow[t]{7}{*}{ O } & 9 & 0,1476 & 0,1456 & 0,0020 & 1,35501 \\
\hline & 10 & 0,1429 & 0,1408 & 0,0021 & 1,46956 \\
\hline & 11 & 0,1491 & 0,1469 & 0,0022 & 1,47552 \\
\hline & 12 & 0,1306 & 0,1291 & 0,0015 & 1,14855 \\
\hline & 13 & 0,1437 & 0,1406 & 0,0031 & 2,15727 \\
\hline & 14 & 0,1390 & 0,1350 & 0,0040 & 2,87707 \\
\hline & 15 & 0,1194 & 0,1168 & 0,0026 & 2,17755 \\
\hline $\mathrm{T}$ & 16 & 0,1313 & 0,1284 & 0,0029 & 2,20868 \\
\hline$A$ & 17 & 0,1353 & 0,1329 & 0,0024 & 1,77384 \\
\hline $\mathrm{N}$ & 18 & 0,1250 & 0,1229 & 0,0021 & 1,68000 \\
\hline$D$ & 19 & 0,1252 & 0,1226 & 0,0026 & 2,07668 \\
\hline \multirow[t]{5}{*}{$\mathrm{Y}$} & 20 & 0,1304 & 0,1279 & 0,0025 & 1,91718 \\
\hline & 21 & 0,1368 & 0,1337 & 0,0031 & 2,26608 \\
\hline & 22 & 0,1246 & 0,1226 & 0,0020 & 1,60514 \\
\hline & 23 & 0,1321 & 0,1291 & 0,0030 & 2,27101 \\
\hline & 24 & 0,1291 & 0,1269 & 0,0022 & 1,70411 \\
\hline
\end{tabular}


TABELA 9 - Massa inicial $\left(M_{1}\right)$, massa final $\left(M_{2}\right)$, diferença $\left(M_{1}-M_{2}\right)$ e percentagem de perda de massa para o cimento de iônomero de vidro Vitremer Diluído 1/4

\begin{tabular}{|c|c|c|c|c|c|}
\hline Pasta & $\begin{array}{l}\text { Corpos de } \\
\text { prova }\end{array}$ & $\begin{array}{c}M_{1} \\
\text { gramas }\end{array}$ & $\begin{array}{c}\mathrm{M}_{2} \\
\text { Gramas }\end{array}$ & $\begin{array}{c}\left(M_{1}-M_{2}\right) \\
\text { gramas }\end{array}$ & $\%$ de perda \\
\hline & 1 & 0,0957 & 0,0906 & 0,0051 & 5,32915 \\
\hline & 2 & 0,0988 & 0,0939 & 0,0049 & 4,95951 \\
\hline$S$ & 3 & 0,0975 & 0,0912 & 0,0063 & 6,46154 \\
\hline 0 & 4 & 0,0925 & 0,0866 & 0,0059 & 6,37838 \\
\hline $\mathrm{R}$ & 5 & 0,0948 & 0,0876 & 0,0072 & 7,59494 \\
\hline $\mathrm{R}$ & 6 & 0,1040 & 0,0982 & 0,0058 & 5,57692 \\
\hline I & 7 & 0,0979 & 0,0936 & 0,0043 & 4,39224 \\
\hline$S$ & 8 & 0,0924 & 0,0870 & 0,0054 & 5,84416 \\
\hline \multirow[t]{7}{*}{0} & 9 & 0,0928 & 0,0882 & 0,0046 & 4,95690 \\
\hline & 10 & 0,0995 & 0,0945 & 0,0050 & 5,02513 \\
\hline & 11 & 0,0941 & 0,0905 & 0,0036 & 3,82572 \\
\hline & 12 & 0,0975 & 0,0930 & 0,0045 & 4,61538 \\
\hline & 13 & 0,0933 & 0,0881 & 0,0052 & 5,57342 \\
\hline & 14 & 0,0903 & 0,0851 & 0,0052 & 5,75858 \\
\hline & 15 & 0,0874 & 0,0844 & 0,0030 & 3,43249 \\
\hline $\mathrm{T}$ & 16 & 0,0946 & 0,0895 & 0,0051 & 5,39112 \\
\hline$A$ & 17 & 0,0993 & 0,0957 & 0,0036 & 3,62538 \\
\hline $\mathrm{N}$ & 18 & 0,0904 & 0,0862 & 0,0042 & 4,64602 \\
\hline D & 19 & 0,0893 & 0,0839 & 0,0054 & 6,04703 \\
\hline \multirow[t]{5}{*}{$\mathrm{Y}$} & 20 & 0,0963 & 0,0911 & 0,0052 & 5,39979 \\
\hline & 21 & 0,0972 & 0,0934 & 0,0038 & 3,90947 \\
\hline & 22 & 0,0938 & 0,0897 & 0,0041 & 4,37100 \\
\hline & 23 & 0,0965 & 0,0920 & 0,0045 & 4,66321 \\
\hline & 24 & 0,0902 & 0,0851 & 0,0051 & 5,65410 \\
\hline
\end{tabular}


A Tabela 10 apresenta a média do desgaste e o desvio padrão de cada grupo, de acordo com a pasta utilizada, Sorriso ou Tandy, no teste de escovação.

TABELA 10 - Porcentagem média da perda de massa e desvio padrão dos grupos estudados

\begin{tabular}{lllll}
\hline Material & Média/Sorriso & Média/Tandy & Desvio/Sorriso & Desvio/Tandy \\
\hline Delton & 2,28319 & 2,53620 & 1,105618 & 0,548585 \\
Ketac-Molar & 1,52472 & 1,73672 & 0,420329 & 0,432242 \\
GC Fuji Plus & 4,12227 & 3,39945 & 0,690283 & 0,403289 \\
Vitremer & 1,26285 & 2,05960 & 0,138136 & 0,354393 \\
Vitremer 1/4 & 5,41333 & 4,87263 & 1,034574 & 0,890190 \\
\hline
\end{tabular}

Os dados da tabela 10 foram submetidos à Análise de Variância a dois critérios (material e dentifrício), como houve interação entre as variáveis, as médias foram comparadas individualmente pelo teste de Tukey, com nível de significância de 5\%, e foram ilustradas na tabela 11.

TABELA 11 - Comparações individuais pelo método Tukey entre as médias obtidas dos percentuais de perda após os testes de escovação

\begin{tabular}{|c|c|c|c|c|c|c|c|c|c|}
\hline Material & Tipo de pasta & $\%$ média de perda & 1 & 2 & 3 & 4 & 5 & 6 & 7 \\
\hline Vitremer $1 / 4$ & Sorriso & 5,41333 & I & & & & & & \\
\hline Vitremer $1 / 4$ & Tandy & 4,87263 & | & | & & & & & \\
\hline GC Fuji Plus & Sorriso & 4,12227 & & | & | & & & & \\
\hline GC Fuji Plus & Tandy & 3,39945 & & & | & | & & & \\
\hline Delton & Tandy & 2,53620 & & & & | & | & & \\
\hline Delton & Sorriso & 2,28319 & & & & & | & | & \\
\hline Vitremer & Tandy & 2,05960 & & & & & | & | & | \\
\hline Ketac-Molar & Tandy & 1,73672 & & & & & | & | & | \\
\hline Ketac-Molar & Sorriso & 1,52472 & & & & & & | & | \\
\hline Vitremer & Sorriso & 1,26285 & & & & & & & | \\
\hline
\end{tabular}

- As barras indicam equivalência estatística 
Através da análise estatística pôde se observar que não houve diferença significante em nível de $5 \%$ de abrasividade entre os dentifrícios Tandy e Sorriso nos cinco grupos de materiais testados, ou seja, em cada um dos grupos experimentais mesmo utilizando pastas diferentes o valor do desgaste foi equivalente (Figura 21).

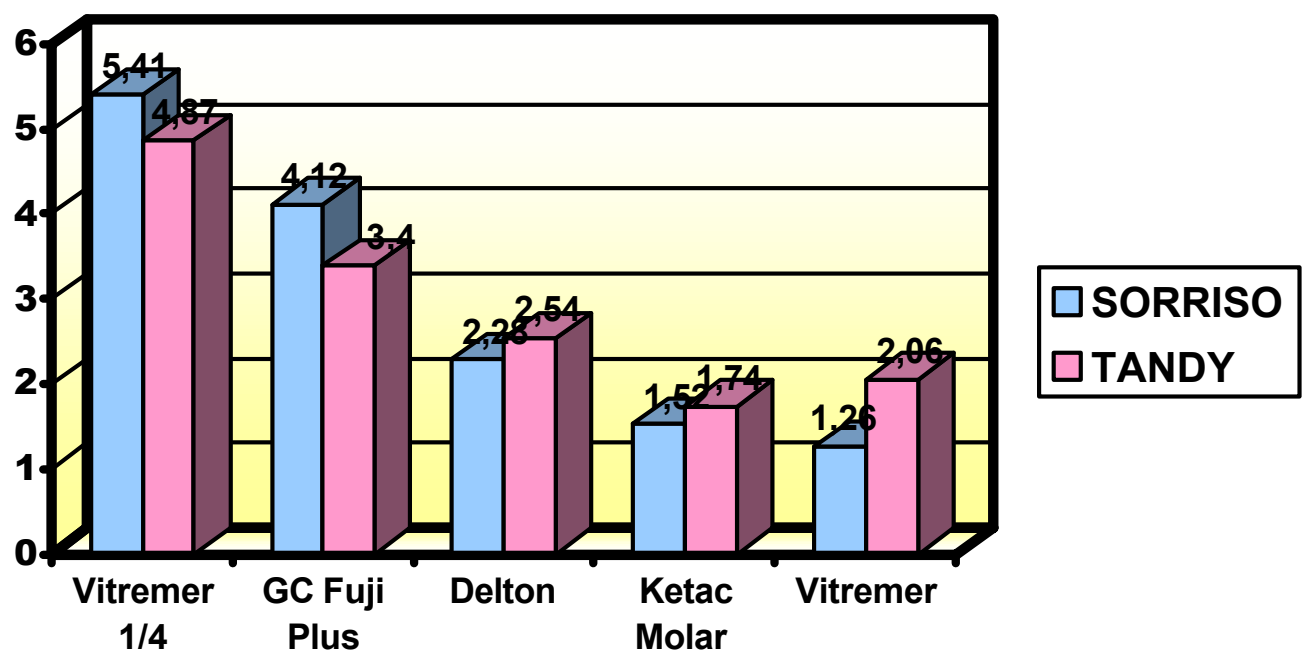

FIGURA 21 - Gráfico comparando a média da porcentagem de desgaste dos materiais (g) utilizando dois diferentes dentifrícios (Sorriso e Tandy)

No entanto, ao se analisar os valores de desgaste de cada material nos testes feitos apenas com o dentifrício Sorriso, verificaram-se as seguintes relações: o grupo do Vitremer diluído foi o que sofreu maior desgaste, seguido do GC Fuji Plus, Delton, KetacMolar, e Vitremer, sendo que não houve diferença estatisticamente significante entre a perda de massa do Delton em relação ao KetacMolar, e deste último em relação ao Vitremer, ressaltando-se que o desgaste do Delton comparado ao do Vitremer foi maior, com significância estatística. (Figura 22). 


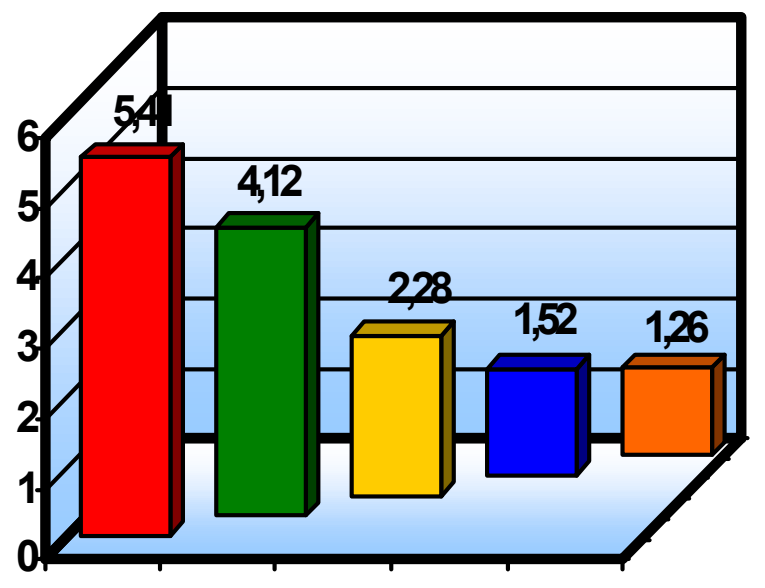

\begin{tabular}{|l|}
\hline QVitremer1/4 \\
afuji \\
aDelton \\
aKetac \\
uVitremer \\
\hline
\end{tabular}

FIGURA 22 - Gráfico da comparação entre as médias da porcentagem de desgaste dos materiais $(\mathrm{g})$ utilizando o dentifrício Sorriso.

Quando se compara a perda de massa entre os grupos, considerando a utilização apenas do dentifrício Tandy, os resultados são ligeiramente diferentes, ocorrendo na seguinte ordem do grupo de maior para o de menor desgaste: Vitremer Diluído, GC Fuji Plus, Delton, Vitremer e Ketac Molar. Porém, não houve diferença estatisticamente significante entre os grupos: Delton / Vitremer, Delton / Ketac Molar, Delton / Fuji, e Ketac Molar / Vitremer (Figura 23).

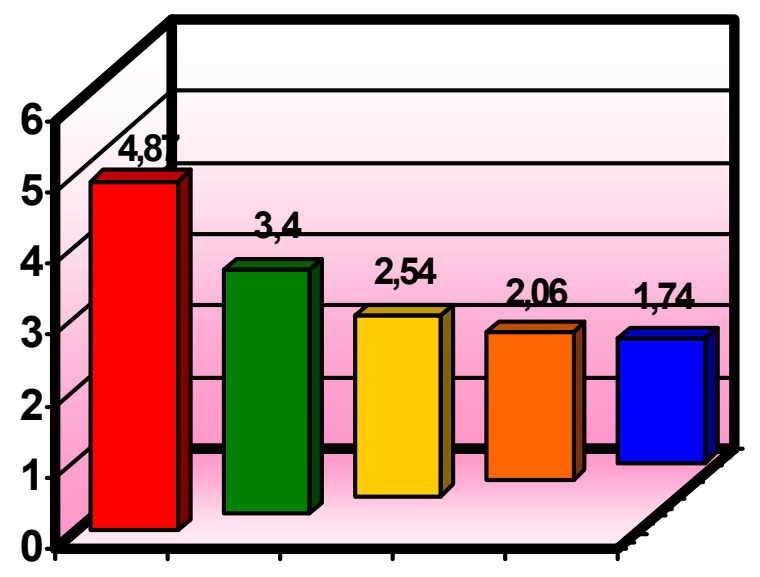

\begin{tabular}{|l|}
\hline$\square$ Vitremer1/4 \\
$\square$ Fuji \\
$\square$ Delton \\
$\square$ Vitremer \\
$\square$ Ketac \\
\hline
\end{tabular}

FIGURA 23 - Gráfico da comparação entre as médias da porcentagem de desgaste dos materiais (g) utilizando o dentifrício Tandy. 


\section{2- RUGOSIDADE}

A média das rugosidades superficial $\left(R_{a}-\mu m\right)$ entre as cinco medições realizadas em todos corpos de prova para cada material, medidas inicialmente $\left(R_{1}\right)$ e ao final $\left(R_{2}\right)$ do teste de escovação (Figura 24), e a diferença entre elas $\left(R_{2}-R_{1}\right)$ serão apresentadas nas Tabelas 12 a 16, sendo que em todas elas os corpos de prova de número 1 a 12 foram submetidos à escovação com o dentifrício Sorriso, e os de número 13 a 24 com o dentifrício Tandy.

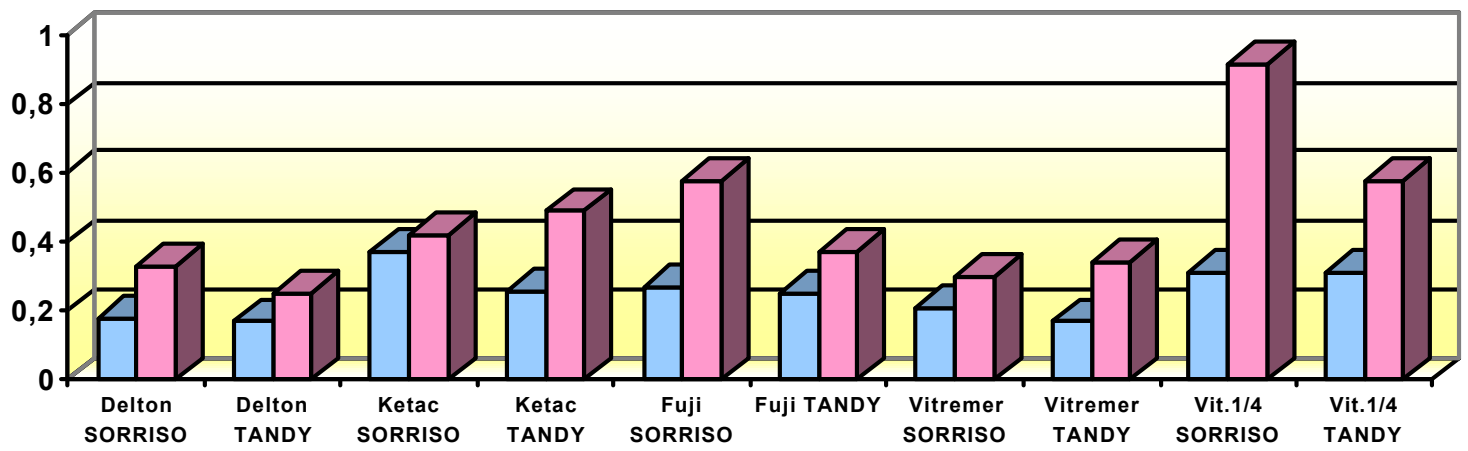

FIGURA 24 - Gráfico comparando as médias de rugosidade $(\mu \mathrm{m})$ dos materiais testados antes e após escovação utilizando dois diferentes dentifrícios (Sorriso e Tandy) 
TABELA 12 - Rugosidade média $(\mu \mathrm{m})$ inicial, final e diferença entre elas para os corpos de prova do material Delton

\begin{tabular}{|c|c|c|c|c|}
\hline Pasta & Material & $\begin{array}{l}\text { Rugosidade } \\
\text { inicial }\end{array}$ & Rugosidade final & Diferença $\left(R_{2}-R_{1}\right)$ \\
\hline & 1 & 0,138 & 0,218 & 0,080 \\
\hline & 2 & 0,070 & 0,194 & 0,124 \\
\hline$S$ & 3 & 0,276 & 0,188 & $-0,088$ \\
\hline $\mathrm{O}$ & 4 & 0,148 & 0,202 & 0,054 \\
\hline $\mathrm{R}$ & 5 & 0,198 & 0,434 & 0,236 \\
\hline $\mathrm{R}$ & 6 & 0,108 & 0,280 & 0,172 \\
\hline 1 & 7 & 0,226 & 0,446 & 0,220 \\
\hline$S$ & 8 & 0,154 & 0,214 & 0,060 \\
\hline \multirow[t]{7}{*}{$\mathrm{O}$} & 9 & 0,112 & 0,260 & 0,148 \\
\hline & 10 & 0,382 & 0,882 & 0,500 \\
\hline & 11 & 0,264 & 0,422 & 0,158 \\
\hline & 12 & 0,064 & 0,208 & 0,144 \\
\hline & 13 & 0,214 & 0,184 & $-0,030$ \\
\hline & 14 & 0,126 & 0,258 & 0,132 \\
\hline & 15 & 0,168 & 0,282 & 0,114 \\
\hline $\mathrm{T}$ & 16 & 0,210 & 0,292 & 0,082 \\
\hline$A$ & 17 & 0,058 & 0,222 & 0,164 \\
\hline $\mathrm{N}$ & 18 & 0,236 & 0,282 & 0,046 \\
\hline $\mathrm{D}$ & 19 & 0,118 & 0,232 & 0,114 \\
\hline \multirow[t]{5}{*}{$\mathrm{Y}$} & 20 & 0,102 & 0,280 & 0,178 \\
\hline & 21 & 0,132 & 0,152 & 0,020 \\
\hline & 22 & 0,174 & 0,238 & 0,064 \\
\hline & 23 & 0,202 & 0,300 & 0,098 \\
\hline & 24 & 0,254 & 0,254 & 0,000 \\
\hline
\end{tabular}


TABELA 13 - Rugosidade média $(\mu \mathrm{m})$ inicial, final e diferença entre elas para os corpos de prova do material Ketac Molar

\begin{tabular}{|c|c|c|c|c|}
\hline Pasta & Material & $\begin{array}{l}\text { Rugosidade } \\
\text { inicial }\end{array}$ & Rugosidade final & Diferença $\left(R_{2}-R_{1}\right)$ \\
\hline & 1 & 0,452 & 0,618 & 0,166 \\
\hline & 2 & 0,568 & 0,616 & 0,048 \\
\hline$S$ & 3 & 0,292 & 0,456 & 0,164 \\
\hline $\mathrm{O}$ & 4 & 0,360 & 0,484 & 0,124 \\
\hline $\mathrm{R}$ & 5 & 0,188 & 0,338 & 0,150 \\
\hline $\mathrm{R}$ & 6 & 0,392 & 0,358 & $-0,034$ \\
\hline I & 7 & 0,382 & 0,316 & $-0,066$ \\
\hline$S$ & 8 & 0,558 & 0,416 & $-0,142$ \\
\hline \multirow[t]{7}{*}{$\mathrm{O}$} & 9 & 0,414 & 0,368 & $-0,046$ \\
\hline & 10 & 0,330 & 0,374 & 0,044 \\
\hline & 11 & 0,296 & 0,264 & $-0,032$ \\
\hline & 12 & 0,226 & 0,388 & 0,162 \\
\hline & 13 & 0,472 & 0,494 & 0,022 \\
\hline & 14 & 0,224 & 0,428 & 0,204 \\
\hline & 15 & 0,322 & 0,540 & 0,218 \\
\hline $\mathrm{T}$ & 16 & 0,282 & 0,436 & 0,154 \\
\hline$A$ & 17 & 0,272 & 0,474 & 0,202 \\
\hline $\mathrm{N}$ & 18 & 0,274 & 0,454 & 0,180 \\
\hline $\mathrm{D}$ & 19 & 0,284 & 0,512 & 0,228 \\
\hline \multirow[t]{5}{*}{$\mathrm{Y}$} & 20 & 0,230 & 0,382 & 0,152 \\
\hline & 21 & 0,224 & 0,388 & 0,164 \\
\hline & 22 & 0,176 & 0,714 & 0,538 \\
\hline & 23 & 0,134 & 0,508 & 0,374 \\
\hline & 24 & 0,292 & 0,556 & 0,264 \\
\hline
\end{tabular}


TABELA 14 - Rugosidade média $(\mu \mathrm{m})$ inicial, final e diferença entre elas para os corpos de prova do material GC Fuji Plus

\begin{tabular}{|c|c|c|c|c|}
\hline Pasta & Material & $\begin{array}{l}\text { Rugosidade } \\
\text { inicial }\end{array}$ & Rugosidade final & Diferença $\left(R_{2}-R_{1}\right)$ \\
\hline & 1 & 0,336 & 0,582 & 0,246 \\
\hline & 2 & 0,530 & 0,852 & 0,322 \\
\hline$S$ & 3 & 0,258 & 0,588 & 0,330 \\
\hline O & 4 & 0,426 & 0,762 & 0,336 \\
\hline $\mathrm{R}$ & 5 & 0,220 & 0,746 & 0,526 \\
\hline $\mathrm{R}$ & 6 & 0,174 & 0,556 & 0,382 \\
\hline I & 7 & 0,192 & 0,610 & 0,418 \\
\hline$S$ & 8 & 0,218 & 0,682 & 0,464 \\
\hline \multirow[t]{7}{*}{$\mathrm{O}$} & 9 & 0,156 & 0,630 & 0,474 \\
\hline & 10 & 0,300 & 0,616 & 0,316 \\
\hline & 11 & 0,272 & 0,634 & 0,362 \\
\hline & 12 & 0,200 & 0,628 & 0,428 \\
\hline & 13 & 0,302 & 0,371 & 0,069 \\
\hline & 14 & 0,190 & 0,354 & 0,164 \\
\hline & 15 & 0,204 & 0,392 & 0,188 \\
\hline $\mathrm{T}$ & 16 & 0,244 & 0,342 & 0,098 \\
\hline$A$ & 17 & 0,284 & 0,358 & 0,074 \\
\hline $\mathrm{N}$ & 18 & 0,272 & 0,354 & 0,082 \\
\hline $\mathrm{D}$ & 19 & 0,370 & 0,386 & 0,016 \\
\hline \multirow[t]{5}{*}{$\mathrm{Y}$} & 20 & 0,242 & 0,450 & 0,208 \\
\hline & 21 & 0,284 & 0,372 & 0,088 \\
\hline & 22 & 0,154 & 0,388 & 0,234 \\
\hline & 23 & 0,236 & 0,366 & 0,130 \\
\hline & 24 & 0,284 & 0,316 & 0,032 \\
\hline
\end{tabular}


TABELA 15 - Rugosidade média ( $\mu \mathrm{m})$ inicial, final e diferença entre elas para os corpos de prova do material Vitremer

\begin{tabular}{|c|c|c|c|c|}
\hline Pasta & Material & $\begin{array}{l}\text { Rugosidade } \\
\text { inicial }\end{array}$ & Rugosidade final & Diferença $\left(R_{2}-R_{1}\right)$ \\
\hline & 1 & 0,258 & 0,236 & $-0,022$ \\
\hline & 2 & 0,330 & 0,204 & $-0,126$ \\
\hline$S$ & 3 & 0,140 & 0,224 & 0,084 \\
\hline $\mathrm{O}$ & 4 & 0,196 & 0,390 & 0,194 \\
\hline $\mathrm{R}$ & 5 & 0,156 & 0,178 & 0,022 \\
\hline $\mathrm{R}$ & 6 & 0,172 & 0,310 & 0,138 \\
\hline I & 7 & 0,330 & 0,390 & 0,060 \\
\hline$S$ & 8 & 0,240 & 0,370 & 0,130 \\
\hline \multirow[t]{7}{*}{$\mathrm{O}$} & 9 & 0,212 & 0,158 & $-0,054$ \\
\hline & 10 & 0,152 & 0,404 & 0,252 \\
\hline & 11 & 0,128 & 0,290 & 0,162 \\
\hline & 12 & 0,252 & 0,474 & 0,222 \\
\hline & 13 & 0,056 & 0,164 & 0,108 \\
\hline & 14 & 0,204 & 0,268 & 0,064 \\
\hline & 15 & 0,160 & 0,412 & 0,252 \\
\hline $\mathrm{T}$ & 16 & 0,164 & 0,282 & 0,118 \\
\hline$A$ & 17 & 0,142 & 0,272 & 0,130 \\
\hline $\mathrm{N}$ & 18 & 0,220 & 0,410 & 0,190 \\
\hline$D$ & 19 & 0,174 & 0,308 & 0,134 \\
\hline \multirow[t]{5}{*}{$Y$} & 20 & 0,226 & 0,466 & 0,240 \\
\hline & 21 & 0,168 & 0,298 & 0,130 \\
\hline & 22 & 0,188 & 0,392 & 0,204 \\
\hline & 23 & 0,212 & 0,508 & 0,296 \\
\hline & 24 & 0,166 & 0,370 & 0,204 \\
\hline
\end{tabular}


TABELA 16 - Rugosidade média $(\mu \mathrm{m})$ inicial, final e diferença entre elas para os corpos de prova do material Vitremer Diluído 1/4

\begin{tabular}{|c|c|c|c|c|}
\hline Pasta & Material & $\begin{array}{l}\text { Rugosidade } \\
\text { inicial }\end{array}$ & Rugosidade final & Diferença $\left(R_{2}-R_{1}\right)$ \\
\hline & 1 & 0,488 & 0,918 & 0,430 \\
\hline & 2 & 0,358 & 0,638 & 0,280 \\
\hline$S$ & 3 & 0,430 & 0,874 & 0,444 \\
\hline O & 4 & 0,334 & 1,092 & 0,758 \\
\hline $\mathrm{R}$ & 5 & 0,226 & 1,552 & 1,326 \\
\hline $\mathrm{R}$ & 6 & 0,250 & 0,950 & 0,700 \\
\hline I & 7 & 0,270 & 0,990 & 0,720 \\
\hline$S$ & 8 & 0,246 & 1,144 & 0,898 \\
\hline \multirow[t]{7}{*}{$\mathrm{O}$} & 9 & 0,296 & 0,498 & 0,202 \\
\hline & 10 & 0,380 & 1,092 & 0,712 \\
\hline & 11 & 0,224 & 0,606 & 0,382 \\
\hline & 12 & 0,242 & 0,706 & 0,464 \\
\hline & 13 & 0,194 & 0,710 & 0,516 \\
\hline & 14 & 0,290 & 0,478 & 0,188 \\
\hline & 15 & 0,342 & 0,178 & $-0,164$ \\
\hline $\mathrm{T}$ & 16 & 0,162 & 0,598 & 0,436 \\
\hline$A$ & 17 & 0,296 & 0,222 & $-0,074$ \\
\hline $\mathrm{N}$ & 18 & 0,360 & 0,688 & 0,328 \\
\hline $\mathrm{D}$ & 19 & 0,336 & 0,762 & 0,426 \\
\hline \multirow[t]{5}{*}{$\mathrm{Y}$} & 20 & 0,414 & 0,852 & 0,438 \\
\hline & 21 & 0,222 & 0,210 & $-0,012$ \\
\hline & 22 & 0,234 & 0,772 & 0,538 \\
\hline & 23 & 0,482 & 0,970 & 0,488 \\
\hline & 24 & 0,362 & 0,566 & 0,204 \\
\hline
\end{tabular}


A Tabela 17 apresenta a média da diferença dos valores obtidos de rugosidade e o desvio padrão de cada grupo, de acordo com a pasta utilizada, Sorriso ou Tandy, no teste de escovação.

TABELA 17 - Porcentagem média da diferença de rugosidade e desvio padrão dos grupos estudados

\begin{tabular}{lllll}
\hline Material & Média/Sorriso & Média/Tandy & Desvio/Sorriso & Desvio/Tandy \\
\hline Delton & 0,150667 & 0,081833 & 0,139777 & 0,064297 \\
Ketac Molar & 0,044833 & 0,225000 & 0,107664 & 0,127936 \\
GC Fuji Plus & 0,383667 & 0,115250 & 0,080326 & 0,069647 \\
Vitremer & 0,088500 & 0,172500 & 0,116401 & 0,069030 \\
Vitremer 1/4 & 0,609667 & 0,276000 & 0,309945 & 0,244988 \\
\hline
\end{tabular}

Os dados da Tabela 17 foram submetidos à Análise de Variância a dois critérios (material/dentifrício), como houve interação entre as variáveis, as médias foram comparadas individualmente pelo teste de Tukey, com nível de significância de 5\%, e foram ilustradas na Tabela 18. 
TABELA 18 - Comparações individuais pelo método Tukey entre as médias obtidas das diferenças de rugosidade após os testes de escovação

\begin{tabular}{|c|c|c|c|c|c|c|}
\hline Material & Tipo de pasta & $\begin{array}{c}\text { \% média da } \\
\text { diferença }\end{array}$ & 1 & 2 & 3 & 4 \\
\hline Ketac-Molar & Sorriso & 0,044833 & I & & & \\
\hline Delton & Tandy & 0,081833 & | & | & & \\
\hline Vitremer & Sorriso & 0,088500 & | & | & & \\
\hline GC Fuji Plus & Tandy & 0,115250 & | & | & & \\
\hline Delton & Sorriso & 0,150667 & | & | & & \\
\hline Vitremer & Tandy & 0,172500 & | & | & & \\
\hline Ketac-Molar & Tandy & 0,225000 & | & | & | & \\
\hline Vitremer $1 / 4$ & Tandy & 0,276000 & & | & | & \\
\hline GC Fuji Plus & Sorriso & 0,383667 & & & | & \\
\hline Vitremer $1 / 4$ & Sorriso & 0,609667 & & & & | \\
\hline
\end{tabular}

- $\quad$ As barras indicam equivalência estatística

De acordo com a Tabela 18, a rugosidade resultante do teste de escovação com o dentifrício Sorriso, em comparação ao dentifrício Tandy, foi estatisticamente maior, nos grupos de materiais GC Fuji Plus e Vitremer Diluído 1/4. Com relação aos outros grupos, Delton, Ketac Molar e Vitremer, não houve diferença significante em nível de $5 \%$ entre a diferença de rugosidade provocada pela utilização de qualquer dos dentifrícios, ou seja, mesmo utilizando pastas diferentes o valor de rugosidade resultante foi semelhante (Figura 25). 


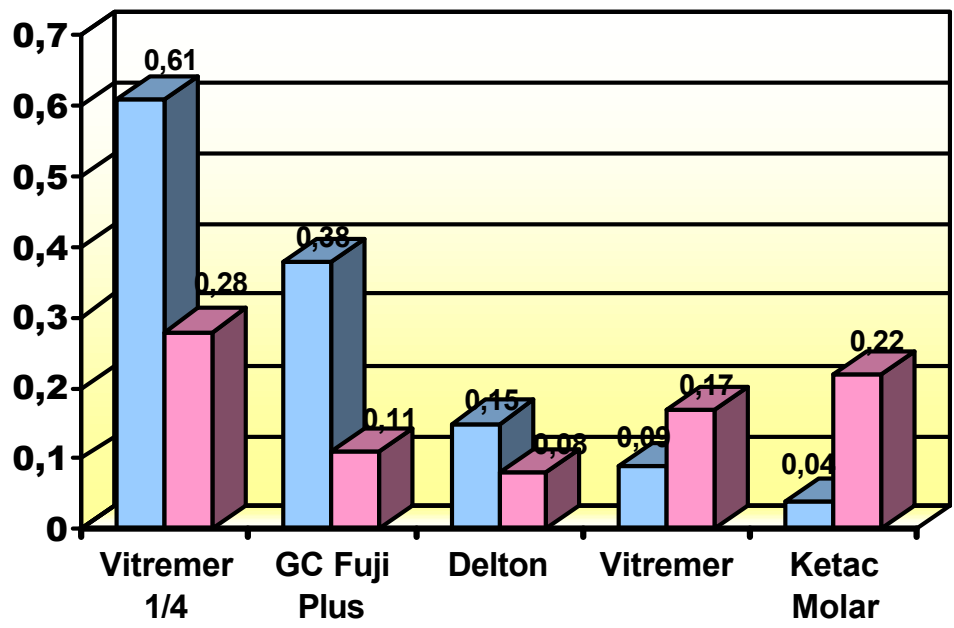

\begin{tabular}{|l|}
\hline OSORRISO \\
QTANDY \\
\hline
\end{tabular}

FIGURA 25 - Gráfico comparando as médias da diferença de rugosidade dos materiais utilizando dois diferentes dentifrícios (Sorriso e Tandy)

Ao se analisar os valores de rugosidade de cada material nos testes feitos apenas com o dentifrício Sorriso, verificou-se que o Vitremer Diluído apresentou maior aumento de rugosidade, seguido pelo GC Fuji Plus, que por sua vez foi maior do que o restante dos materiais e estes apresentaram equivalência estatística quando comparados entre si (Figura 26).

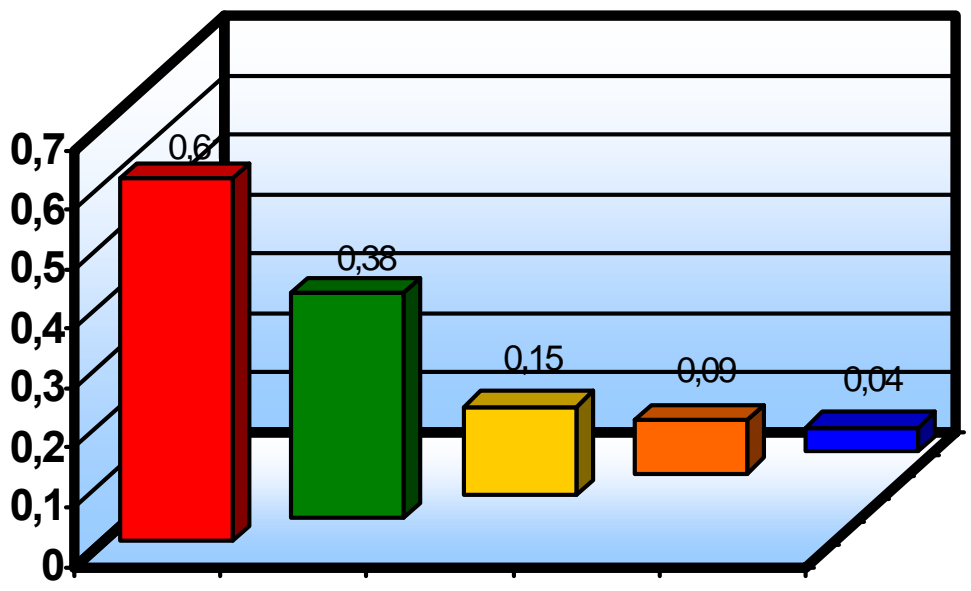

\begin{tabular}{|l|}
\hline Vitremer1/4 \\
$\square$ Fuji \\
$\square$ Delton \\
$\square$ Vitremer \\
$\square$ Ketac \\
\hline
\end{tabular}

FIGURA 26 - Gráfico da comparação entre as médias das diferenças de rugosidade dos materiais utilizando o dentifrício Sorriso 
No entanto, a comparação da rugosidade inicial com a final entre os grupos de materiais, considerando a utilização apenas do dentifrício Tandy, demonstrou que o Vitremer Diluído 1/4 apresentou maior rugosidade que os quatro grupos restantes e estes, quando comparados entre si, também apresentaram equivalência estatística (Figura 27).

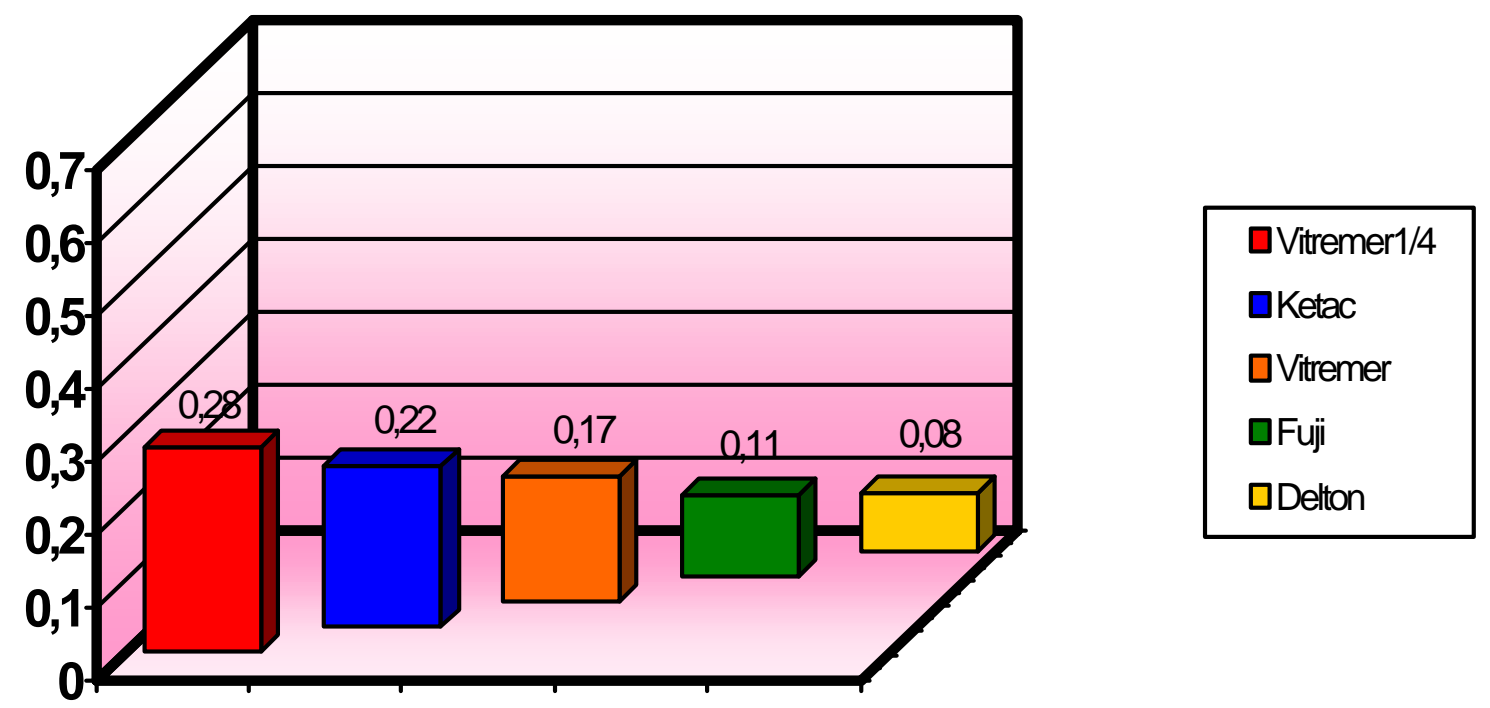

FIGURA 27 - Gráfico da comparação entre as médias das diferenças de rugosidade dos materiais utilizando o dentifrício Tandy

\section{3- CORRELAÇÃO}

Pelo Método Casewise MD verificou-se a correlação entre a porcentagem da perda de massa e a diferença da rugosidade sem distinção do tipo de material testado ou tipo de pasta utilizada. $O$ índice de correlação encontrado foi $r=-, 6472$, pode se concluir que houve uma correlação, porém seu valor é médio. 
6. DISCUSSÃo 


\section{6- DISCUSSÃO}

\section{1- Procedimento selador}

As fossas e fissuras são áreas anatômicas da superfície oclusal dos dentes, susceptíveis à cárie em função da sua morfologia ${ }^{86}$ associada à possibilidade de ocorrência de uma má coalescência do esmalte nestas regiões ${ }^{10,68,84}$. Essas características morfológicas facilitam a retenção de resíduos alimentares, constituindo um nicho para a proliferação de bactérias, acrescidas da dificuldade de limpeza mecânica através da escovação e pela ação restrita do mecanismo tampão da saliva nas partes mais profundas das fissuras, ${ }^{13,43,44}$.

Outro fator que contribui para a maior susceptibilidade das superfícies oclusais é o grau de mineralização do dente durante a fase de erupção quando o esmalte ainda não sofreu "maturação póseruptiva" se apresentando mais poroso e menos resistente à desmineralização ${ }^{19,67}$.

Estudos epidemiológicos têm mostrado uma maior prevalência de cárie em superfícies de fossas e fissuras, principalmente as oclusais, em comparação com as superfícies lisas ${ }^{10,82}$. A preocupação com estas áreas vem sendo descrita desde o final do século passado quando BLACK, preconizou a extensão preventiva do preparo, ou seja, estendia-se o preparo até regiões de fossas e fissuras, mesmo 
estas estando hígidas, para prevenir o aparecimento de lesões cariosas $^{43,44,67}$. Durante a década de 1920, duas técnicas clínicas diferentes foram idealizadas na tentativa de reduzir a extensão e a severidade das cáries oclusais ${ }^{44}$. Em 1924, HYATT $^{45}$ apresentou a odontomia profilática, procedimento invasivo incluindo todas fossas e fissuras hígidas e posterior restauração com amálgama; e BODECKER $^{8}$ em 1929 introduziu a erradicação mecânica das fissuras, eliminando sua retentividade e profundidade para facilitar a higienização. Sabe-se hoje que esses conceitos estavam equivocados.

Com a mudança da Filosofia Odontológica, de restauradora para preventiva, devido à maior conscientização da importância da conservação de estrutura dentária sadia, além do desenvolvimento e aprimoramento dos materiais restauradores, pesquisaram-se novas alternativas para a prevenção da instalação de lesões cariosas em fissuras. A partir do advento do ataque ácido em esmalte, em 1955 por BUONOCORE ${ }^{9}$, iniciou-se um verdadeiro desenvolvimento dos materiais resinosos e paralelamente idealizou-se o procedimento de selamento das fóssulas e fissuras ${ }^{38}$.

Os selantes são substâncias capazes de escoar nas fossas e fissuras, penetrando nas microporosidades do esmalte previamente condicionado formando projeções (tags) de resina ${ }^{36,47,82}$. O objetivo do 
selamento de fossas e fissuras é, juntamente com a exposição ao flúor e à pratica da higiene bucal, formar uma barreira física impedindo - acúmulo de placa, e assim limitar a ocorrência da cárie oclusal $^{47,85,10}$. A proteção do selante à base de Bis-GMA será efetiva enquanto houver retenção e integridade do material selador ${ }^{68}$. Além disso o procedimento de ataque ácido do esmalte pode diminuir aproximadamente $75 \%$ dos microrganismos presentes na fissura ${ }^{46}$.

Vários estudos clínicos foram conduzidos a fim de comprovar a eficiência do selamento ${ }^{36,38,46,87,100}$. Em 1976, o Conselho de Materiais Dentários, Instrumentos e Equipamentos da $\mathrm{ADA}^{14}$ ratificou a segurança e eficácia dos selantes de fossas e fissuras como medida preventiva da cárie, salientando que eles deveriam fazer parte de um amplo programa preventivo, sendo associado a outras medidas complementares. Alguns anos depois, em 1983 houve uma conferência que reafirmava a efetividade e segurança dos procedimentos seladores $^{68}$.

Em 1991, em um estudo clinico de 15 anos sobre selantes, SIMONSEN ${ }^{93}$ verificou que $69 \%$ das superfícies estavam hígidas após uma única aplicação de selante, ao passo que quando comparadas ao grupo controle sem tratamento, $83 \%$ das superfícies se encontravam cariadas ou restauradas, comprovando a longo prazo a importância do selamento. 
No entanto, na década de 70, alguns autores questionaram a utilização do selamento devido à ocorrência de lesões cariosas nas margens entre o material e a estrutura dentária ${ }^{5,84}$. Esta falha ocorreu em virtude da falta de cuidados durante os passos operatórios do procedimento clínico ${ }^{5}$. O material até então utilizado, a resina, é extremamente sensível à técnica, devendo observar-se o adequado isolamento do campo, preferencialmente absoluto, para que não ocorra alterações do material em função da contaminação ${ }^{91}$. Outro passo importante é o ataque ácido do esmalte, aparentemente simples, porém muitas vezes negligenciado ${ }^{36,37,91}$, não sendo, desta forma, aplicado em toda extensão preenchida posteriormente pelo selante. Por outro lado, outro fator que pode comprometer o sucesso do selante é sua aplicação, que pode ser feita em excesso, atingindo áreas de esmalte não condicionadas. Nestas situações, existirão áreas de adesão superficial do material, sem a formação de tags, consequentemente após determinado período de tempo haverá o descolamento do selante nestas áreas, promovendo a degradação marginal e formando regiões de difícil acesso à higienização e nichos de colonizaçã para bactérias ${ }^{36}$. A ilustração esquemática do fenômeno foi demonstrada na Figura 28. 


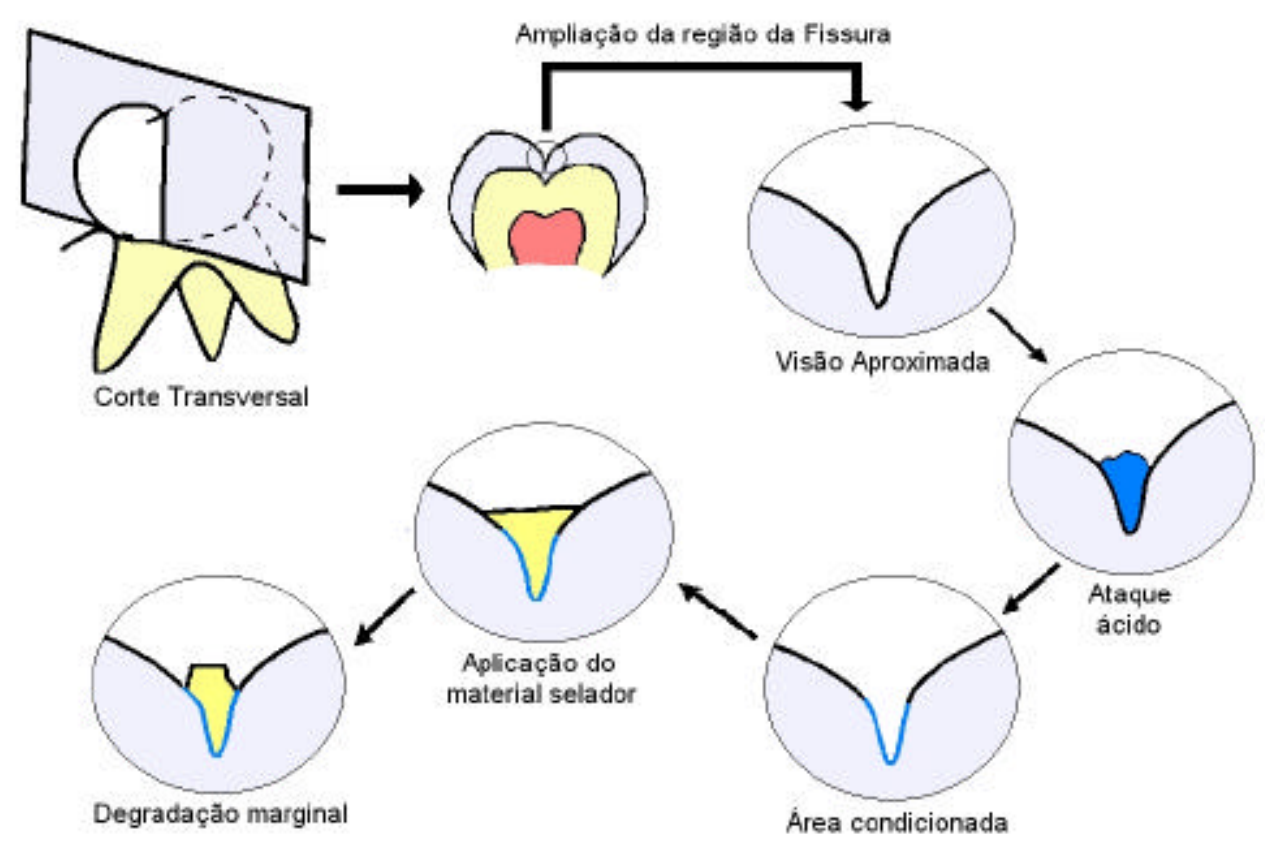

FIGURA 28 - Ilustração da conseqüência da aplicação inadequada dos selantes resinosos.

Existem situações onde o procedimento selador é fundamental, como nos casos dos dentes semi irrompidos, fase em que a superfície oclusal se encontra mais susceptível ao processo carioso, mas há restrições quanto ao uso de materiais resinosos, devido à impossibilidade de isolamento da área ${ }^{19,36}$.

Em 1972, WILSON e KENT ${ }^{110}$ desenvolveram um novo material, o cimento de ionômero de vidro (CIV), com propriedades favoráveis que despertaram o interesse em torná-lo uma alternativa para 0 selamento de fóssulas e fissuras. Os cimentos ionoméricos além de formarem a barreira física, possibilitada pela sua capacidade de 
adesão à estrutura mineralizada do dente, teriam a ação química em função de sua habilidade em liberar e absorver flúor. Sendo assim McLEAN e WILSON ${ }^{61,62}$ introduziram o uso clínico do CIV como selante obtendo resultados positivos.

Vários estudos foram conduzidos no intuito de comprovar a eficiência dos selantes ionoméricos ${ }^{4,5,25,31,48,50,92}$, inclusive em uma revisão de pesquisas clínicas, TYAS ${ }^{106}$ confirmou o objetivado na literatura quanto à existência de divergências relacionadas à retenção e um consenso a respeito de sua ação na prevenção de cáries.

A diferença de resultados pode ser atribuída à metodologia utilizada. Em estudos onde se comparou o exame clínico direto com o microscópico por réplicas constatou-se a dificuldade da exatidão da avaliação clínica $^{63}$, pois em muitas situações onde os selantes ionoméricos não eram visualizados, ao exame microscópico, estes se localizavam no fundo das fissuras, sendo que em contrapartida houve casos onde clinicamente havia retenção total dos selantes resinosos, e microscopicamente eles se encontravam apenas parcialmente retidos $^{63}$, conduta extremamente prejudicial para este tipo de material. Além disso há dificuldade em distinguir entre o desgaste do selante e perda do material $^{19}$.

Apesar da importância dessas considerações, não se pode negligenciar o fato de que apesar dos índices de retenção dos 
selantes de cimento de ionômero de vidro serem baixos, a incidência de cárie também é pequena, evidenciando a capacidade do material no controle da cárie oclusal ${ }^{104}$. A perda clínica do material pode causar a falsa impressão de fracasso, no entanto a eficiência do selante ionomérico não depende apenas desta propriedade, já que a permanência de microfragmentos do material na fissura mantêm o efeito anticariogênico proporcionado pela liberação de flúor ${ }^{4,89}$.

A literatura e a experiência clínica nos levam a concluir que o ionômero de vidro é uma excelente alternativa para o selamento de fossas e fissuras, principalmente em dentes recém-erupcionados, onde há um difícil controle da umidade não sendo, portanto indicada a utilização de materiais resinosos ou a espera de condições ideais para seu uso, em virtude deste período ser uma época crítica com relação ao desenvolvimento de cáries ${ }^{4,83}$.

A quantidade de liberação de flúor entre os ionômeros é diferente mas ocorre em todos eles, inclusive nos modificados por resina. De maneira geral, a liberação é maior nos primeiros dias e posteriormente vai diminuindo até atingir um valor constante ${ }^{26}$. Estes materiais possuem também a propriedade de recarregamento de flúor, sendo capazes de absorver o íon presente nos dentifrícios, na água e nas aplicações tópicas, e depois o liberarem ${ }^{26,40,49}$. Contudo, deve-se haver cautela na aplicação tópica de flúor fosfato acidulado nos 
cimentos ionoméricos pois o recarregamento ocorre às custas de uma degradação do material, pois o ácido presente causa uma erosão irreversível $^{72}$.

A influência da queda do $\mathrm{pH}$ no aumento da liberação de flúor, apesar de ocorrer em conseqüência de dissolução do material é favorável, pois grandes quantidades de flúor em baixo $\mathrm{pH}$ resultam em uma melhor proteção à estrutura dentária contra a desmineralização ${ }^{29}$.

O desenvolvimento dos cimentos de ionômero de vidro modificados por resina propiciou a utilização do condicionamento do esmalte com ácido fosfórico a $37 \%$ para promover uma maior retenção do selante $^{76}$. Em 1994, SUNDFELD ${ }^{101}$ conduziu estudo laboratorial paralelamente ao clínico, verificando a penetração do ionômero nas microporosidades criadas pelo ataque ácido do esmalte, cuja conseqüência prática foi uma retenção satisfatória do material.

A proposta de diluir o Vitremer na proporção de $1 / 4$ da concha de pó para uma gota de líquido surgiu pela necessidade de obtenção de um material mais fluido com maior capacidade de penetração no fundo das fissuras, possibilitando uma maior retenção micromecânica. Esta modificação vem sendo utilizada clinicamente, apresentando resultados satisfatórios ${ }^{55}$. Quanto à influência da modificação da consistência do material em sua capacidade de liberar flúor, vários trabalhos indicam uma relação positiva, ou seja, quanto mais diluído o 
ionômero, maior sua liberação de flúor ${ }^{15,16}$. Apesar de parecer contraditório, pelo íon se encontrar presente no pó, este fenômeno é explicado na reação química formadora do material. Alguns autores encontraram que o flúor é liberado sob a forma de fluoreto de sódio, decomposto durante a reação de formação do cimento ${ }^{62}$, advindo da matriz. Quando há mais água ou mais ácido a extração de íons da superfície do pó é maior, consequentemente mais íons flúor serão envolvidos na matriz e decompostos ${ }^{16}$.

As propriedades dos cimentos de ionômero de vidro são influenciadas pela composição e pela relação entre pó e líquido, baseados nisso comparamos as propriedades de desgaste e rugosidade, do cimento convencional (Ketac Molar), do modificado por resina com consistência restauradora (Vitremer), e experimentalmente diluída (Vitremer 1/4), e um outro cimento modificado por resina cimentante (Fuji Plus), com consistência fluida desenvolvida pelos fabricantes.

\section{2- Propriedade de desgaste}

No presente estudo, foi avaliada a abrasividade do dentifrício Tandy, especialmente desenvolvido para crianças, possuindo largo 
consumo, e como parâmetro de comparação foi utilizado o dentifrício Sorriso, de ampla utilização pela população brasileira.

As desvantagens do estudo in vivo como o tempo requerido e inabilidade de interpretação dos resultados com relação aos mecanismos responsáveis por gerar o desgaste em função da ocorrência de uma enormidade de variáveis, foram consideradas contraindicando sua realização ${ }^{21,42,52}$.

O padrão de desgaste dos materiais odontológicos, nas condições bucais, ocorre por abrasão, erosão e/ou fadiga do material, que por sua vez, são influenciados pelo contato com substâncias químicas, escovação dental e forças oclusais ${ }^{20,30,88}$. Idealmente, no caso específico do procedimento selador, o material deve ser aplicado na fase de erupção do dente, não sofrendo este tipo de desgaste. Os selantes ionoméricos são extremamente sensíveis à ação erosiva de substâncias químicas ${ }^{60}$, sendo que neste trabalho foi avaliada a ação do dentifrício.

A decisão por utilizar um teste in vitro de abrasividade dos dentifrícios e simultaneamente um teste de desgaste dos materiais foi baseada nos achados de HAFFERREN ${ }^{42}$ que afirmou a necessidade do passo laboratorial para entender a situação clínica. Além disso, há relato de correlação positiva entre dados obtidos in vivo e in vitro ${ }^{22}$. 


\section{3- Propriedade de rugosidade}

A rugosidade é o conjunto de pequenas irregularidades, menos espaçadas do que as ondulações, podendo ser considerada superposta a uma superfície ondulada, e esta, ocasionalmente superposta a uma superfície com erro de forma. Pode ser quantificada através da associação de valores, possibilitando a comparação entre superfícies $^{30}$.

Todos materiais possuem um determinado valor de rugosidade e diversos fatores podem atuar sobre as superfícies, acarretando em mudança de suas características ${ }^{11}$. Neste trabalho a ação mecânica da escovação aliada à abrasividade do dentifrício, foram os fatores responsáveis pela alteração da rugosidade dos materiais seladores.

A ocorrência de um aumento da rugosidade acarreta em uma maior área de superfície, podendo aumentar ao acúmulo de placa. SMALES $^{97}$ encontrou associação, in situ, entre a rugosidade superficial das restaurações e a quantidade de placa presente, inclusive o CIV foi considerado o mais rugoso e o que obteve maior quantidade placa. Outro pesquisador SKJORLAND ${ }^{96}$ demonstrou in vitro que a topografia da superfície dos materiais, inclusive os poros, não exerce influência na aderência inicial de bactérias. No entanto, devemos considerar a influência do material restaurador na adesão 
bacteriana e na quantidade de micorganismos presentes na placa $^{75,102,103}$, pois vários estudos constataram uma menor quantidade de Streptococcus mutans presentes na placa de cimentos ionoméricos, associando o fenômeno à liberação de flúor, que pode agir como um inibidor enzimático interferindo no metabolismo de carboidratos $^{75}$ ou reduzindo a acidogenicidade da placa, não favorecendo o desenvolvimento de S. mutans ${ }^{102}$. Além disso PALENIK et $\mathrm{al}^{78}$. demonstraram laboratorialmente o efeito inibidor do CIV sobre o crescimento e adesão de bactérias. FORSS et al. ${ }^{23}$ esclareceram estas questões comparando os níveis de flúor ao crescimento de S. mutans presentes nas placas de restaurações, concluindo que apesar da quantidade de placa ser semelhante entre os materiais, maiores níveis de flúor estavam sempre associados a menores níveis do microrganismo.

Assim sendo, apesar da rugosidade estar associada ao acúmulo de placa, nos ionômeros de vidro este fator é minimizado pela liberação de flúor. Nestes materiais, a quantidade da placa pode ser grande, porém possuindo um menor potencial cariogênico ${ }^{23,102}$. 


\section{4- Metodologia}

Durante a confecção dos corpos de prova, procurou-se obter lisura superficial, através de tiras de poliester; não sendo feito polimento já que este não faz parte do procedimento clínico ${ }^{30}$. O ganho ou perda de água foram evitados, através da aplicação de protetores $^{104}$ (esmalte e Finishing Gloss) e aguardando-se 24 horas (presa tardia) para o armazenamento em água, com o intuito de que não ocorressem alterações irreversíveis dos ionomêros, modificando suas propriedades ${ }^{15,16,26,29,111,112}$, o que acarretaria alterações nos resultados dos testes.

Para avaliação do desgaste optou-se pela análise de perda de massa ao invés de sistema de mensuração de profundidade (Perfilômetro), pois esta medida sendo realizada em diferentes posições ao início e ao final da escovação poderá trazer resultados com variações ${ }^{20}$, enquanto a pesagem mostra claramente a quantidade de massa perdida. HEFFERREN ${ }^{42}$ descreveu que 0 melhor método seria a contagem radioativa do material desgastado, contraindicando a perda de peso, uma vez que a variação do conteúdo de água do material afetaria esta medida. No entanto, esta limitação foi superada através da medição diária até que o corpo de 
prova atingisse equilíbrio, ou seja permanecesse com a mesma medida em cinco medições consecutivas ${ }^{1}$.

$\mathrm{Na}$ literatura, existem várias metodologias para simular laboratorialmente o desgaste, entre elas o método incorporando abrasão e fadiga ${ }^{58}$, método de simulação por $\operatorname{carga}^{22}$, método de desgaste em combinação ${ }^{51}$, sendo todos eles inadequados, pelo fato dos selantes estarem em áreas sem contato oclusal. $O$ teste que melhor se enquadrou para nossa proposição foi o de escovação, correspondendo a um desgaste a três corpos, em virtude da interação entre dente/material, dentifrício (intermediário) e escova. Nos desgastes a dois corpos, as substâncias intermediárias não estão presentes $^{58}$.

A máquina de escovação utilizada neste trabalho foi especialmente construída para simular, simultaneamente algumas variáveis que podem ocorrer no processo de higiene oral (pressão, velocidade, abrasividade e umidade), sendo semelhante à máquina tipo Pepsodent utilizada em diversos outros trabalhos ${ }^{20,65}$.

Os dentifrícios utilizados foram diluídos em água deionizada como preconizam HEATH; WILSON ${ }^{41}$, para simular a diluição que ocorre na boca pela saliva, e para reduzir a sedimentação do abrasivo, não acarretando em uma ação de atrito. Durante a escovação, a espuma formada se movimentava para fora dos 
recipientes, sendo a grande responsável pela renovação constante do dentifrício, pois os corpos de prova necessitavam estar sempre imersos na solução.

Um aspecto muito importante com relação aos dentifrícios, é o valor do pH após a diluição, principalmente quando se trabalha com cimento de ionômero de vidro ${ }^{29,32}$, visto que o pH altera a composição química do ionômero, podendo acarretar em dissolução do material. A existência de dentifrícios ácidos é justificada pelo fato do $\mathrm{pH}$ poder influenciar na ação dos componentes básicos dos dentifrícios (os detergentes), e esse fator é considerado na elaboração de sua composição para garantir a ação dessas substâncias ${ }^{79}$.

Foram utilizados dois métodos de medição, o indicador universal de Merck, onde os valores são obtidos por meio da comparação de cores com uma escala padrão, sendo de interpretação individual e imprecisa; e o pHmetro, que estabelece valores exatos. Para certificação da estabilização do pH do dentifrício diluído durante sua utilização no teste de escovação, ele foi medido em intervalos de uma hora, e não se verificou variação. Caso os valores de Merck fossem considerados, o $\mathrm{pH}$ do dentifrício Tandy seria ácido $(\mathrm{pH}=6)$ acarretando em mudanças de interpretação dos resultados.

Para avaliação da rugosidade foi utilizado o rugosímetro. Um outro aparelho, que apesar de atuar de forma distinta, fornece os 
mesmos dados quanto às características da superfície, é o perfilômetro. O parâmetro escolhido para avaliar a rugosidade foi o Desvio Médio Aritmético $\left(\mathrm{R}_{\mathrm{a}}\right)$, também designado CLA (Center Line Avarage), que é a média dos valores absolutos das ordenadas do perfil em relação à linha média, em um comprimento de amostragem $^{6,11}$. $R_{a}$ é o valor de escolha para critério de especificação de rugosidade pela ABNT, e o mais utilizado de acordo com a NBR $6405^{6}$

$\mathrm{Na}$ tentativa de abranger os valores de rugosidade de toda superfície, foram feitas cinco medições $\left(R_{a} / \mu m\right)$ em direções diferentes e o valor total correspondeu a média destes valores.

A microscopia eletrônica de varredura é um meio qualitativo para avaliação de uma superfície, no entanto as técnicas quantitativas, como a rugosimetria, permitem uma avaliação mais precisa das superfícies $^{30}$.

\section{5- Resultados}

O conhecimento da forma como ocorre o desgastes nos cimentos de ionômero de vidro é importante para a compreensão da discussão dos resultados. O CIV é composto basicamente por partículas de vidro envoltas por uma matriz de polissais ${ }^{98}$ e quando 
submetidos à ação específica da escovação, ocorre um desgaste gradual da matriz, promovendo a exposição cada vez maior das partículas de vidro, até que estas se desprendam ${ }^{65}$. Este fênomeno foi ilustrado na Figura 29. Bolhas de ar podem ser incorporadas na massa ionômérica durante sua mistura e o nível de desgaste pode também atingir estas áreas, expondo uma maior superfície ${ }^{20,33}$.

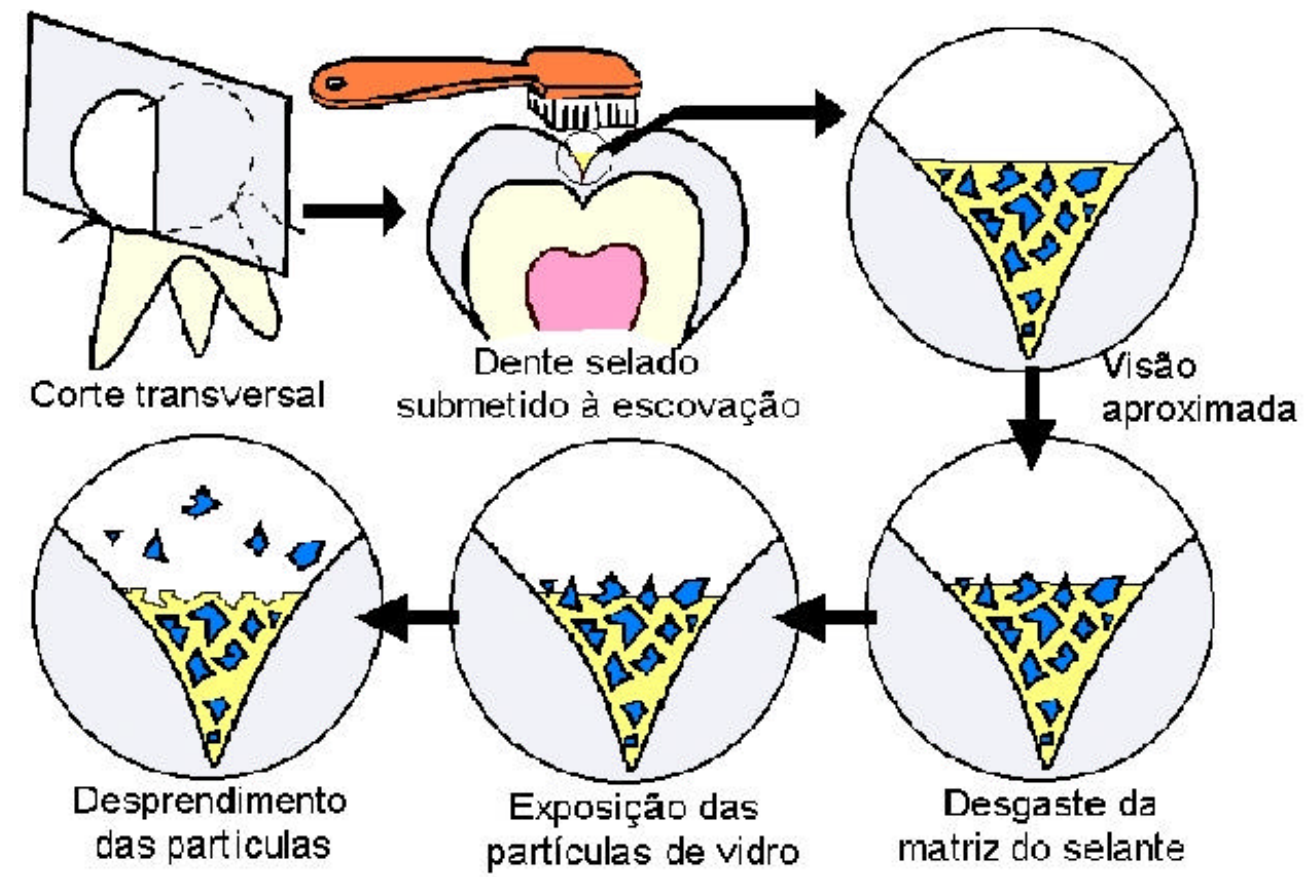

FIGURA 29 - Ilustração do processo de desgaste dos C.I.V.

Vários autores realizaram em um único estudo a avaliação do desgaste e da rugosidade provocada pela escovação, consequentemente há uma tendência de se correlacionar estas duas propriedades. 
Entretanto no teste estatístico o valor dessa correlação foi $r=0,6472$, um valor médio, impedindo a afirmação com base científica de que o desgaste esteja intimamente ligado à rugosidade. Dois tipos de materiais podem sofrer quantitativamente o mesmo desgaste, no entanto, na análise da superfície, um deles pode apresentar uma maior exposição das partículas ou de bolhas de ar, acarretando em um maior valor de rugosidade. Isto ocorre em função das diferentes distribuições espaciais entre eles de suas partículas e uma maior ou menor inserção de ar durante a mistura, desta forma esclarecendo que o comportamento relacionado ao desgaste não é necessariamente igual ao da rugosidade e justificando os diferentes comportamentos dos ionômeros, quanto a estas propriedades ${ }^{56,112}$.

A análise do desgaste deve ser multifatorial, ou seja, deve considerar os vários fatores que influenciam seu resultado. A maioria destes fatores como o tipo de escova; velocidade, pressão, movimento e tempo de escovação; quantidade e diluição do dentifrício foi padronizada para que os únicos fatores determinantes da diferença de comportamento entre os materiais fossem suas próprias características e as dos dentifrícios. A comparação dos resultados obtidos aos de outros trabalhos se torna inviável em função da utilização de metodologia e materiais variados. 
A ação abrasiva do dentifrício é influenciada pelo tipo, tamanho, dureza e corte das partículas, e pelo seu $\mathrm{pH}^{2,79,80}$. Apesar de existirem estudos a respeito da composição dos dentifrícios e suas partículas $^{39,80}$, não há relato a respeito dos dentifrícios, Tandy e Sorriso, utilizados. Além disso, o fabricante não forneceu informações sobre seus produtos justificando respeito ao segredo industrial.

Apesar do $\mathrm{pH}$ ser especificado na embalagem dos dentifrícios, foi necessária nova medição, em virtude da sua diluição. Constatou-se um valor de 6,9 para a Tandy ( $\mathrm{pH}$ neutro) e 8,9 para a Sorriso $(\mathrm{pH}$ básico). Em ambos casos, a possível ação química de erosão dos dentifrícios sobre os materiais potencializando o desgaste, não ocorreu, pois não houve acidez capaz de interferir na composição dos ionômeros ${ }^{32}$.

A pasta Tandy é do tipo gel, possuindo a propriedade de tixotropismo, ou seja, ao ser pressionada contra uma superfície ela sofre um espalhamento, obtendo um poder de deslizamento maior comparativamente à pasta do tipo creme $(\text { Sorriso })^{79}$. Apesar de neste estudo o desgaste depender da interação das características dos dentifrícios e dos materiais ${ }^{41}$, podemos afirmar que não houve diferença de abrasividade entre os dois dentifrícios considerando todos os materiais, e mesmo ao se analisar suas ações em um único tipo de material, esta foi estatisticamente semelhante. 
A propriedade de desgaste também está relacionada a alguns fatores inerentes aos materiais. As características da matriz, se é formada apenas por redes de polissais (CIV convencional) ou se há adição de redes de polímeros (CIV modificado por resina); o número, formato e tamanho das partículas inorgânicas de vidro e a formação de bolhas durante a manipulação de mistura dos ionômeros irão influenciar no seu comportamento quando submetidos ao desgaste ${ }^{7,33,35,56,98}$.

O selante ionomérico que sofreu maior desgaste foi o Vitremer diluído (1/4), seguido pelo Fuji Plus também apresentando uma constituição mais fluida. Este comportamento era esperado pois as partículas de vidro responsáveis pela maior resistência ${ }^{69}$, estão presentes em menor quantidade em ambos os casos. Face ao desenvolvimento do Fuji Plus em uma forma previamente diluída, o fabricante procurou compensar esta diluição através da diminuição do tamanho das partículas de vidro, aumentando a área de superfície a ser reagida com o ácido poliacrílico, formando uma maior quantidade de matriz e uma menor incorporação de $\operatorname{ar}^{33,98}$, justificando seu melhor comportamento em relação ao ionômero experimentalmente diluído.

O selante resinoso sem carga, Delton, apesar de apresentar mínima quantidade de partículas inorgânicas, possui matriz de redes 
poliméricas mais resistentes quando comparadas à matriz ionomérica, sendo o terceiro material a sofrer maior desgaste.

Devido à interação entre as variáveis, quando se utilizou o dentifrício Sorriso, o desgaste do Delton foi estatisticamente semelhante ao do Ketac Molar que por sua vez foi semelhante ao do Vitremer, no entanto o desgaste deste foi menor em relação ao Delton. Ao se utilizar o dentifrício Tandy, o comportamento dos três materiais, Delton, Vitremer e Ketac Molar foram semelhantes.

Alguns autores afirmam que a adição de componentes resinosos aos ionômeros tornam sua matriz mais resistente ${ }^{90}$, enquanto outros relatam que o embaraçamento entre as redes resinosas com a matriz ionomérica é deficitário tornando a matriz resultante menos resistente $^{33}$, porém no presente estudo o CIV convencional e o modificado por resina apresentaram comportamentos semelhantes quanto ao desgaste.

Sendo o selante resinoso o padrão de comparação, tanto o ionômero convencional quanto o modificado por resina, ambos em consistência restauradora, se comportaram favoravelmete. No entanto, outras propriedades devem ser consideradas para que estes sejam os materiais mais indicados para o selamento. 
A propriedade de rugosidade também é influenciada pelas características dos dentifrícios em interação com as características dos materiais, já explicadas anteriormente.

A rugosidade superficial é resultante da protusão de partículas e exposição de porosidades (bolhas internas de ar), podendo ser decorrente de vários fenômenos, neste caso, como não houve a ação erosiva pelo dentifrício ( $\mathrm{pH}$ neutro e básico) os materiais estiveram submetidos apenas ao desgaste (Figura 29) ${ }^{11,33,30 \text {, }}$

Indepentente da pasta utilizada, o material que apresentou maior aumento de rugosidade superficial foi o Vitremer diluído, e a rugosidade resultante da abrasividade do dentifrício Sorriso, por sua vez, foi estatisticamente maior que a do Tandy nos grupos deste material e no Fuji Plus, no entanto nos outros grupos testados a rugosidade proporcionada foi semelhante.

Analisando a superfície apenas dos corpos de prova escovados com Tandy, os grupos Delton, Vitremer, Ketac Molar e Fuji Plus apresentaram equivalência estatística; com Sorriso ocorreu resultado semelhante com exceção do grupo Fuji Plus, apresentando rugosidade maior em relação aos outros.

Novamente, os materiais que comparativamente apresentaram piores resultados de rugosidade decorrentes do teste de escovação foram primeiramente o Vitremer diluído, seguido pelo Fuji Plus. Este 
fenômeno pode ter ocorrido devido à maior exposição e/ou deslocamento das partículas inorgânicas, e maior quantidade e exposição de porosidades incorporadas à massa destes materiais ${ }^{33}$. Mais estudos a respeito das partículas dos dentifrícios usados, juntamente com o estudo microscópico da superfície dos materiais e de seus componentes, são necessários para esclarecer a interação ocorrida entre eles, permitindo maior entendimento a respeito do desgaste e rugosidade resultantes.

Existe uma busca incessante de materiais odontológicos ideais, como um cimento ionomérico selador capaz de conciliar sua propriedade química de liberação de flúor com uma lisura superficial constante e uma alta resistência ao desgaste, diminuindo sua degradação e sua susceptibilidade à fraturas evitando seu deslocamento da superfície.

É importante enfatizar que o material selador, mesmo possuindo propriedades ideais, apenas obterá sucesso quando bem indicado. A utilização do selamento não pode ser generalizada através do uso indiscriminado para todo e qualquer paciente, devendo-se, portanto, avaliar a necessidade individual de cada caso. CARVALHO et.al ${ }^{12}$. confirmam que é possível manter a superfície oclusal íntegra sem o uso de selantes, por meio de um programa individualizado de controle de cárie. 


\section{CONCLUSÕES}




\section{CONCLUSÕES}

Baseados nos resultados obtidos, considerando-se que houve interação entre a abrasividade dos dentifrícios e as propriedades dos materiais, pode-se concluir que:

- Não houve diferença estatisticamente significante quanto a abrasividade dos dentifrícios Tandy e Sorriso sobre três CIV e um selante resinos,

- Os materiais que sofreram maior desgaste foram em ordem decrescente: Vitremer diluído e Fuji Plus,

- Em relação à rugosidade superficial dos materiais avaliados após o teste de escovação, a ação do dentifrício Sorriso nos grupos Vitremer diluído e Fuji Plus resultou em superfícies estatisticamente mais rugosas quando comparadas aquelas sob a ação do Tandy,

- A avaliação estatística do aumento da rugosidade superficial do grupo Vitremer diluído, mostrou que ela foi significantemente maior, quando comparado aos demais materiais. 


\section{REFERÊNCIAS BIBLIOGRÁFICAS}




\section{REFERÊNCIAS BIBLIOGRÁFICAS}

1. AKER, J.R. New composite resins: comparison of their resistence to toothbrush abrasion and characteristics of abraded surfaces. J. Amer. dent. Ass., v.105, n.10, p. 633-5, Oct. 1982.

2. AMERICAN DENTAL ASSOCIATION. Americam National standard. Specification no. 37 for dental abrasive powders, p.319-31, 1986.

3. AMERICAN DENTAL ASSOCIATION. Americam National standard. Specification no. 66 for dental glass ionomer cements, p.1-10, 1989.

4. ARANDA, M.; GARCIA-GODOY, F. Clinical evaluation of the retention and wear of a light-cured pit and fissure glass ionomer sealant. J. clin. Pediat. Dent., v.19, n.4, p.273-7, Summer 1995.

5. ARROW, P.; RIORDAN, P.J. Retention and caries preventive effects of a GIC and a resin-based fissure sealant. Community Dent. oral Epidem., v.23, n.5, p.282-5, Oct. 1995.

6. ASSOCIAÇÃO BRASILEIRA DE NORMAS TÉCNICAS. Rugosidade das superfícies: procedimentos. NBR 6405, 1988.

* Normas recomendadas para uso no âmbito da Universidade de São Paulo, com base no documento "Referências Bibliográficas: exemplos", emanado do Conselho Supervisor do Sistema Integrado de Bibliotecas da USP, em reunião de 20 de setembro de 1990. 
7. BARRA, E.; HILL, R.G. Influence of alkali metal ions on the fracture properties of glass polyalkenoate (ionomer) cements. Biomaterials, v.19, n.6, p.495-502, Mar. 1998.

8. BODECKER, C.F. The eradication of enamel fissures. Dent. Intems. Interest., v.51, p.859, 1929 apud HICKS, M.J. ${ }^{44}$ P.492.

9. BUONOCORE, M.G. A simple method of increasing the adhesion of acrylic filling materials to enamel surfaces. J. dent. Res., v.34, n.6, p.849-53, Dec. 1955.

10. BUONOCORE, M.G. Adeshive sealing of pits and fissures for caries prevention with use of ultraviolet light. J. Amer. dent. Ass., v.80, n.2, p.324-8, Feb. 1970.

11. CARPINETTI, L.C.R. et al. Rugosidade superficial: conceitos e princípio de medição. São Carlos, Seção de Publicações da EESC-USP, 1996.

12 CARVARLHO, J.C.; THYLSTRUP, A.; EKSTRAND, K.R. Results after 3 years of non operative occlusal caries treatment of erupting permanent first molars. Community Dent. oral Epidem., v.20, n.4, p.187-92, Aug. 1992.

13. CONRY, J.P.; PINTADO, M.R.; DOUGLAS, W.H. Quantitative changes in fissure sealant six months after placement. Pediat. Dent., v.12, n.3, p.162-6, May/june. 1990.

14. COUNCIL ON DENTAL MATERIALS AND DEVICES. Pit and fissure sealants. J. Amer. dent. Ass., v.93, n.1, p.134, July 1976.

15. CRANFIELD, M.; KUHN, A.T.; WINTER, G.B. Factors relating to the rateof fluoride-ion release from glass-ionomer cement. $\mathbf{J}$. Dent., v.10, n.4, p.333-41, July/Aug. 1982. 
16. CRISP, S.; LEWIS, B.G.; WILSON, A.D. Glass ionomer cements: chemistry of erosion. J. dent. Res., v.55, n.6, p.1032-41, Nov./Dec. 1976.

17. DAVIES, E.H.; SELFTON, J.; WILSON, A.D. Preliminary study of factors affecting the fluoride release from glass-ionomer cements. Dent. Mat., v.14, n.8, p.636-9, Aug. 1993.

18. DE BOER, P.; DUINKERKE, A.S.H.; ARENDS, J. Influence of tooth paste particle size and tooth brush stiffness on dentine abrasion in vitro. Caries Res., v.19, n.3, p.232-9, May/June 1985.

19. DENNISON, J.B.; STRAFFON, L.H.; MORE, F.G. Evaluating tooth eruption on sealant efficacy. J. Amer. dent. Ass., v.121, n.5, p.610-4, Nov. 1990.

20. DOMENE, S. Determinação da perda de massa, pelo método da escovação, nos cimentos ionômeros de vidro. Bauru, 1998. 85p. Tese (Doutorado) - Faculdade de Odontologia de Bauru, Universidade de São Paulo.

21. EHRNFORD, L. et al. An abrasion test for composite resins. J. dent. Res., v.59, n.4, p.716-20, Apr. 1980.

22 FINGER, W.; THIEMANN, J. Correlation between in vitro and in vivo wear of posterior restorative materials. Dent. Mat., v.3, n.5, p.280-6, Oct. 1987.

23. FORSS, $H$. et al. Fluoride and mutans streptococci in plaque grown on glass ionomer and composite. Caries Res., v.25, n.6, p.454-8, Nov./Dec. 1991.

24. FORSS, H. Release of fluoride and otrer elements from lightcured glass ionomers in neutral and acidic conditions. J. Dent. Res., v.72, n.8, p.1257-62, Aug. 1993. 
25. FORSS, H.; SAARNI, U-M.; SEPPA, L. Comparison of glassionomer and resin-based fissure sealants: a 2-year clinical trial. Community Dent. oral Epidem., v.22, n.1, p.21-4, Jan/Fev. 1994.

26. FORSTEN, L. Fluoride release and uptake by glass ionomers. Scand. J. dent. Res., v.99, n.3, p.241-5, June 1991.

27. FORSTEN, L. Fluoride release and uptake by glass-ionomers and related materials and its clinical effect. Biomaterials, v.19, n.6, p.503-8, Mar. 1998.

28. FORSTEN, L. Resin-modified glass ionomer cements: fluoride release and uptake. Acta. odont. scand., v.53, n.4, p.222-5, Aug. 1995.

29. FORSTEN, L. Short-and long-term fluoride release from glass ionomers and other fluoride-containing filling materials in vitro. Scand. J. dent. Res., v.98, n.2, p.179-85, Apr. 1990.

30. FOSSEN, A.M. Estudo "in vitro"da rugosidade superficial de resinas compostas do tipo híbrida e de micropartículas submetidas a diversas técnicas de polimento. São Paulo, 1994. 47p. Dissertação (Mestrado) - Faculdade de Odontologia de São Paulo, Universidade de São Paulo.

31. FRAGA, L.R.L. Avaliação clínica, no período de 33 meses, da incidência de cárie, retenção e desgaste de materiais híbridos de ionômero de vidro/resina composta utilizados como selantes de fóssulas e fissuras. Piracicaba, 1999. 111p. Tese (Doutorado) - Faculdade de Odontologia de Piracicaba, Universidade Estadual de Campinas. 
32 FUKAZAWA, M.; MATSUYA, S.; YAMANE, M. Mechanism for erosion of glass-ionomer cements in na acidic buffer solution. J. dent. Res., v.66, n.12, p.1770-4, Dec. 1987.

33. GLADYS, S. et al. Comparative physico-mechanical characterization of new hybrid restorative materials with conventional glass-ionomer and resin composite restorative materials. J. dent. Res., v.76, n.4, p.883-94, Apr. 1997.

34. GRABENSTETTER, R.J. et al. The measurement of the abrasion of human teeth by dentifrice abrasives: a test utilizing radioactive teeth. J. dent. Res., v.37, n.6, p.1060-8, Nov./Dec. 1958

35. GUGGENBERGER, R.; MAY, R.; STEFAN, K.P. New trends in glass-ionomer chemistry. Biomaterials, v.19, n.6, p.479-84, Mar. 1998.

36. GWINNETT, A.J. Scientific rationale for sealant use and technical aspects of application. Caries Res., v.48, p.56-9, Feb. 1984. Supplement 2.

37. GWINNETT, A.J.; RIPA, L.W. Penetration of pit and fissure sealants into conditioned human enamel in vivo. Arch. oral Biol., v.18, n.3, p.435-9, Mar. 1973.

38. HALDELMAN, S.L.; SHEY, Z. Michael Buonocore and the eastman dental center: a historic perspective on sealants. J. dent. Res., v.75, n.1, p.529-34, Jan. 1996.

39. HARRINGTON, E. et. al. Toothbrush-Dentifrice abrasion. Brit. dent. J., v.153, n.4, p.135-8, Aug. 1982.

40. HATIBOVIC-KOFMAN, S.; KOCH, G. Fluoride release from glass ionomer cement in vivo and in vitro. Swed. dent. J., v.15, n.6, p.253-8, Dec. 1991 
41. HEATH, J.R; WILSON, H.J. Abrasion of restorative materials by toothpaste. J. oral. Rehab., v.3, n.2, p.121-38, Apr. 1976

42 HEFFERREN, J.J. A laboratory method for assesment of dentrifrice abrasivity. J. dent. Res., v.55, n.4, p. 563-73, July/Aug. 1976.

43. HENDERSON, H.Z.; SETCOS, J.C. Selantes de fóssulas e fissuras. In: Mc DONALD, R.; AVERY, D.R. Odontopediatria. 6.ed. Rio de Janeiro, Guanabara Koogan, 1995. Cap.17, p.263-271.

44. HICKS, M.J. Atécnica de ataque ácido na prevenção de cáries: selantes de fóssulas e fissuras e restaurações preventivas de resina. In: PINKHAM, J.R. Odontopediatria da infância à adolescência. 2ed. São Paulo, Artes Médicas, 1996. Cap.32, p.486-519.

45. HYATT, T.P. Occlusal fissures: their frequency and danger. How shall they be tretead. Dent. Intems. Interest., v.46, p.493, 1924 apud HICKS, M.J. ${ }^{44}$ p.492.

46. JENSEN, O.E.; HANDELMAN, S.L. Effect of an autopolymerizing sealant on viability of microflora in occlusal dental caries. Scand. J. dent. Res., v.88, n.5, p.382-8, May 1980.

47. JOAN, L.G. Pit and fissure sealants: A revew of the Literature. J, dent. Hyg., v.71, n.4, p.150-8, Summer 1997.

48. JONHSON, L. M. et al. Examination of resin-modified glass ionomer materials as pit and fissure sealant. Quintessence int., v.26, n.12, p.879-83, Dec. 1995

49. $\mathrm{KOCH}, \mathrm{G}$.; HATIBOVIC-KOFMAN, S. Glass ionomer cements as a fluoride release system in vivo. Swed. dent. J., v. 14, n.6, p. 267-73, Nov/Dec. 1990. 
50. KOMATSU, $\mathrm{H}$. et al. Caries-preventive effect of glass ionomer sealant reapplication: study presents three-year results. J. Amer. dent. Ass., v.125, p.543-9, May 1994.

51. KREJEI, I.; LUTZ, F.; ZELDER, C. Effects of contact area size on enamel and composite wear. J. dent. Res., v.71, n.7, p.14136, July 1992.

52 LEINFELDER, K.F.; WILDER, A.D.; TEIXEIRA, L.C. Wear rates of posterior composite resins. J. Amer. dent. Ass., v.112, n.6, p.829-33, June 1986.

53. LEITÃO, J.; HEGDAHL, T. On the measuring of roughness. Acta. odont. scand., v.39, n.6, p.379-84, June 1981.

54. LOVADINO, J.R. et al. Avaliação de dois materiais utilizados como selante oclusal: ionômero X compósito. Rev. Ass. Paul. Cirurg. Dent., v.48, n.1, p.1243-6, Jan./Fev. 1994.

55. MACHADO M.A.A.M. et al. Evaluación de pretratamientos del esmalte en la retención de un cemento de ionómero de v'drio aplicado como sellante. In: REUNIÓN ANUAL DE LA SOCIEDAD ARGENTINA DE INVESTIGACION ODONTOLOGICA, 32, Mar del Plata, 1999. Programa y resumenes de trabajo. Buenos Aires, IADR-Division Argentina, 1999. R.269

56. MATHIS, R.S.; FERRACANE, J.L. Properties of a glassionomer/resin-composite hybrid material. Dent. Mat., v.5, n.5, p.355-60, Sept. 1989.

5. MC CABE, J.F. Resin-modified glass ionomers. Biomaterials, v.19, n.6, p.521-8, Mar. 1998. 
58. MC CABE, J.F.; SMITH, B.H. A method for measuring the wear of restorative materials in vitro. Brit. dent. J., v.151, n.18, p.1236, Aug. 1981.

59. MC KENNA, E.F.; GRUNDY, G.E. Glass ionomer cement fissure sealants applied by operative dental auxiliaries - retention rate after one year. Aust. dent. J., v.32, n.3, p.200-3, June 1987.

60. MC KINNEY, J.E.; WU, W. Chemical softening and wear of dental composites. J. dent. Res., v.64, n.11, p.1326-31, Nov. 1985.

61. MC LEAN, J.W.; WILSON, A.D. Fissure sealing and filling with na adhesive glass-ionomer cement. Brit. dent. J., v.136, n.2, p.269-76, Apr. 1974.

62 McLEAN, J.W.; WILSON, A.D. The clinical development of the glass-ionomer cement. II. Some clinical aplications. Aust. dent. J., v.22, n.2, p.120-7, Apr. 1977.

Ђ. MEJÀRE, I.; MJÓR, I.A. Glass ionomer and resin-based fissure sealants: a clinical study. Scand. J. dent. Res., v.98, n.21, p.345-50, Aug. 1990.

64. MILLER, W.D. Experiments and observation on the wasting of tooth tissue variously designated as erosion, abrasion, chemical abrasion, denudation, etc. Dent. Cosmos, v.49, n.1, p.1-247, Jan./Feb./Mar. 1907 apud SAMUEL, S.M.W. ${ }^{88}$ p. 4.

65. MOORE, B.K.; WINKLER, M.M.; EWOLDSEN, N. Laboratory testing of light-cured glass ionomers as pit and fissure sealants. Gen. Dent., v.43, n.2, p.176-80, Mar./Apr. 1995.

66. MURRAY, I.D.; McCABE, J.F.; STORER, R. Abrasivity of denture cleaning pastes in vitro and in situ. Brit. dent. J., v.161, n.4, p.137-41, Aug. 1986. 
67. MYAKI, S.I.; BRUNETTI, A.L.L.H.; CORREA, M.S.N.P. Selantes de fossas e fissuras. In: CORREA, M.S.N.P. Odontopediatria na primeira infância. São Paulo, Santos Ed., 1998. Cap.26, p.341-54.

68. NATIONAL INSTITUTES OF HEALTH. Consensus development conference statement on dental sealents in the prevention of tooth decay. J. Amer. dent. Ass., v.108, n.2, p. 233-6, Feb. 1984.

69. NAVARRO, M.F.L.; PASCOTTO, R.C. Cimentos de lonômero de vidro. In: . Cimentos de lonômero de vidro São Paulo, Artes Médicas, 1998. Cap.1, 1-21.

70. NAVARRO, M.F.L.; PASCOTTO, R.C. Indicações, contraindicações e cuidados durante a técnica clínica. In:

Cimentos de Ionômero de vidro São Paulo, Artes Médicas, 1998. Cap.2, 25-39.

71. NAVARRO, M.F.L.; PASCOTTO, R.C. Uso em odontopediatria. In: . Cimentos de lonômero de vidro São Paulo, Artes Médicas, 1998. Cap.3, 41-68.

72 NEUMAN, E.; GARCIA-GODOY, F. Effect of APF gel on a glass ionomer cement: na SEM study. J. dent. Child., v.59, n. 4, p. 289-95, July/Aug. 1992.

73. NEWBRUN, E. Preventing dental caries: current and prospective stratagies. J. Amer. dent. Ass., v.123, n.5, p.68-73, May 1992.

74. NICHOLSON, J.W. Chemistry of glass-ionomer cementes: a review. Biomaterials, v.19, n.6, p.485-94, Mar. 1998. 
75. NORMAN, R.D. et. al. Effects of restorative materials on plaque composition. J. dent. Res., v.51, n.6, p.1596-601, Nov/Dec. 1972.

76. OLIVEIRA JÚNIOR, O.B. et al Avaliação clínica da retenção do cimento de ionômero de vidro utilizado como selante oclusal. Efeito do condicionamento ácido do esmalte. Rev. bras. Odont., v.51, n.6, p.59-63, nov./dez. 1994.

77. OVREBO, R.C.; RAADAL, M. Microleakage in fissures sealed with resin or glass ionomer cement. Scand. J. dent. Res., v.98, n.1, p.66-9, Feb. 1990.

78. PALENIK, C.J. et. al. Inhibition of microbal adherence and growth by various glass ionomers in vitro. Dent. Mat., v.8, n.1, p.1620, Jan. 1992.

79. PANZERI, H. et. al. Avaliação de dentifricios I - consistência, densidade, $\mathrm{pH}$, "vida útil" e perda de água. Odont. mod., v.4, n.3, p.4-10, maio/jun. 1978.

80. PANZERI, H. et. al. Avaliação de dentifricios II - forma e distribuição das partículas abrasivas. Odont. mod., v.4, n.4, p.5-18, jul./ago. 1979.

81. PANZERI, H. et. al. Avaliação de dentifricios III - desgaste provocado por escovação 'in vitro". Odont. mod., v.6, n.2, p. 26-32, Feb. 1979.

82 PARK, K.; PENUGONDA, B. Pit and fissure sealants. N. Y. St. Dent. J., v.58, n.4, p.27-9, Apr. 1992.

83. RAADAL, M.; UTKILEN, A.B.; NILSEN, O.L. Fissure sealing with a light-cured resin-reinforced glass-ionomer cement (Vitrebond) compared with a resin sealant. Int. J. Paed. Dent. v.6, n.4, p.235-9, Dec. 1996. 
84. RIPA, L.W. Occlusal sealants: rationale and review of clinical trials. Int. dent. J., v.30, n.2, p.127-39, June 1980.

85. RIPA, L.W. Sealant revisted: an update of the effectiveness of pitand-fissure sealants. Caries Res., v.27, p.77-82, 1993. Supplement 1.

86. ROHR, M.; MAKINSON, O.F.; BURROW, M.F. Pits and fissures: morphology clinic. J. Dent. Child., v.58, n.2, p.97-103, Mar./April 1991.

87. ROYDHOUSE, R.H. Prevention of occlusal caries by use of sealant: a pilot study. J. dent. Child., v.35, n.3, p.253-62, May 1968.

88. SAMUEL, S.M.W. Estudo "in vitro" da rugosidade superficial de materiais restauradores submetidos a ensaio de escovação. Piracicaba, 1993. 116p. Tese (Doutorado) Faculdade de Odontologia de Piracicaba, Universidade Estadual de Campinas.

89. SEPPA, S.; FORSS, H. Resistance of oclusal fissures to demineralization after loss of gass ionomer sealants in vitro. Pediat. Dent., v.13, n.1, p.39-42, Jan./Feb. 1991

90. SHIMOKOBE, $H$. et al. Clinical evaluation of glass ionomer cement used for sealants. J. dent. Res., v.65, p.812, June/Dec. 1986. Special Issue. /Abstract n.780/

91. SILVERSTONE, L.M.; HICKS, M.J.; FEATHERSTONE, M.J. Oral fluid contamination of etched enamel surfaces: na SEM study. J. Amer. dent. Ass., v.110, n.3, p.329-32, Mar. 1985.

92 SIMONSEN, R.J. Glass ionomer as fissure sealant-a critical review. J. Publ. HIth. Dent., v.56, p.146-9, 1996. Special issue 3. 
93. SIMONSEN, R.J. Retention and effectiveness of dental sealant after 15 years. J. Amer. dent. Ass., v.122, n.10, p.34-42, Oct. 1991.

94. SIPAHIER, M.; ULUSU, T. Glass-ionomer-silver-cermet cements applied as fissure sealants II. Clinical evaluation. Quintessence Int., v.36, n.1, p.43-8, Jan. 1995.

95. SIPAHIER, M.; ULUSU, T. Glass-ionomer-silver-cermet cements applied as fissure sealants I. In vitro evaluation. Quintessence Int., v.36, n.1, p.37-42, Jan. 1995.

96. SKJORLAND, K.K. et al. Tooth colored dental retorative materials: porosities and surface topography in relation to bacterial adhesion. Acta. odont. scand., v.40, n.2, p.113-20, Mar./Apr. 1982.

97. SMALES, R.J. Plaque growth on dental restorative materials. J. Dent., v.9, n.2, p.133-40, June 1981 apud SAMUEL, S.M.W. ${ }^{88}$ p. 24.

98. SMITH, D.C. Development of glass-ionomer cement systems. Biomaterials, v.19, n.6, p.467-78, Mar. 1998.

99. STOOKEY, G.K.; MUHLER, J.C. Laboratory studies concerning the enamel and dentin abrasion properties of common dentifrice polishing agents. J. dent. Res., v.47, n.4, p.524-32, July/Aug. 1968.

100. STRAFFON, L.H.; DENNISON, J.B.; MORE, F.G. Three-year evaluation of sealant: effect of isolation on efficacy. J. Amer. dent. Ass., v.110, n.5, p.714-7, May 1985. 
101. SUNDFELD, R.H. et al. Selamento oclusal com ionômero de vidro fotopolimerizável - uma proposta altamente eficaz na prevenção da cárie dental. Âmbito odont., v.1, n. 16, p. 3-7, jan./fev. 1994.

102. SVANBERG, M.; KRASSE, B.; ORNERFELDT, H.O. Mutans streptococci in interproximal plaque from amalgam and glass ionomer restorations. Caries Res., v.24, n.2, p.133-6, Mar./Apr. 1990.

103. SVANBERG, M.; MJOR, I.A.; ORSTAVIK, D. Mutans streptococci in plaque from margins of amalgam, composite, and glassionomer restorations. J. dent. Res., v.69, n.3, p.861-4, Mar. 1990.

104. TAPETY, C.M.C. et al. Effectiveness of surface protection of resin modified glass-ionomer cements evaluated espectrophotometrically. J. dent. Res., v.78, p.228, June/Dec. 1999. Special issue. /Abstract n.979/

105. TYAS, M.J. Cariostatic effect of glass ionomer cement: a five year clinical study. Austr. dent. J., v.36, n.3, p.236-9, June 1991.

106. TYAS, M.J. Clinical studies related to glass ionomers. Oper. Dent., v.17, p.191-8, 1992. Supplement 5.

107. VERBEECK, R.M.H. et al. Fluoride release process of (resin modified) glass-ionomer cements versus (polyacid-modified) composites resins. Biomaterials, v.19, n.6, p.509-20, Mar. 1998.

108. VONO, B.G.; VONO, A.Z.; FIGUEIREDO, M.C. Técnica invasiva de selamento de fóssulas e fissuras: comparação entre selante com carga e com flúor e ionômero de vidro. Rev. FOB, v.4, n.3/4, p.9-16, jul./dez. 1996. 
109. WILLIAMS, B.; WINTER, G.B. Fissure sealants - further results at 4 years. Brit. dent. J., v.150, n.7, p.183-7, Apr. 1981.

110. WILSON, A.D.; KENT, B.E. A new translucent cement for dentistry - the glass ionomer cement. Brit. Dent. J., v.132, n.4, p.133-5, Feb. 1972.

111. YIP, H.-K.; LAM, W.T.C.; SMALES, R.J. Fluoride release, weight loss and erosive wear of modern aesthetic restoratives. Brit. dent. J., v.187, n.5, p.265-70, Sept. 1999.

112. YIP, H.-K.; LAM, W.T.C.; SMALES, R.J. Surface roughness and weight loss of esthetic restorative materials related to fluoride release and uptake. J. clin. Pediat. Dent., v.23, n.4, p.321-6, 1999. 
Abstract 


\section{ABSTRACT}

WEAR AND SUPERFICIAL ROUGHNESS OF MATERIALS USED AS FISSURES SEALANTS, SUBMITTED TO TOOTHBRUSHING TEST WITH TWO DIFFERENTS DENTIFRICES

The purpose of this study was to evaluate, in vitro, some properties (wear and roughness) of glass ionomers ciment that could influence its indication as pit and fissures sealants. Simultaneously it was evaluated the abrasion of two dentifrices (Tandy and Sorriso) and its influence on the roughness surface. The materials used were Fuji Plus (luting cement), Ketac-molar and Vitremer (both restorative cements). This last material was prepared in two proportions: one in accordance with the manufacturer's instructions (1:1) and the other in a diluted form (1/4:1). The resin-based sealant, Delton, chemically activated, was used as control. Using an electronic analytical balance, wear was measured by the level of loss weight, in 12 specimens groups for each material and for each dentifrice, after submitting then to the toothbrushing test. The superficial roughness was determined by a quantitative analysis of the specimens surface, after toothbrushing test, using a rugometer apparatus. The results were analyzed by the two-ways ANOVA criterion and the Tukey test at $p$ $<0.05$. The two dentifrices abrasivity were similar for the five groups tested. Compared with the other materials, diluted Vitremer and Fuji 
Plus resisted less to tooth brushing abrasion. The resulting roughness in the diluted Vitremer and Fuji Plus groups, tooth brushed with Sorriso, were greater as compared to Tandy, while in the other groups the action of the dentifrices were similar. The material that had the most increase on superficial roughness was diluted Vitremer, the others presented estatistical equivalent results, except for Fuji Plus, that showed the second greatest roughness when submitted to dentifrice Sorriso. Though In clinical situations the material often used as an alternative for resin-based sealants are the luting or diluted cements, the results of the study "in vitro" showed that these kind of cements have worse properties than the restorative ionomers which revealed similar results when compared to the evaluated resin sealant. 